\title{
HAKLI NEDENLE FESİH BAKIMINDAN SUÇ VE SUÇU BÍLDİRME YÜKÜMLÜLÜĞÜ
}

DOI: https://doi.org/10.33717/deuhfd.899941

\author{
Arş. Gör. E. Sıla HAFIZO ĞLU*
}

\section{$\ddot{O} z$}

İş Kanunu'nda, iş sözleşmesinin feshi bakımından bazı suçlar doğrudan haklı neden olarak kabul edilmiştir. Ayrıca bir suça açıkça yer verilmemiş haklı neden hükümlerinde sayllan pek çok durum ve davranıs da Türk Ceza Kanunu'ndaki bir suç kapsamına girebilecek niteliktedir. Ceza yargllamasındaki maddi olgu tespitlerinin bağlayıcılı̆̆ ve özellikle iş sözleşmesi taraflarının suçu bildirme yükümlülükleri dikkate alındığında Iş Kanunu m. 24 ve m. 25 'deki haklı nedenlerin suç bağlamında incelenmesi gerekir.

\section{Anahtar Kelimeler}

Haklı Neden Olarak Suçlar, İş Sözleşmesinin Haklı Nedenle Feshi, Ahlak ve Iyi Niyet Kurallarına Uymayan Haller ve Benzerleri, Suçu Bildirmeme Suçları, İş Sözleşmesi Bakımından Suçu Bildirme Yükümlülüğ̈̈, Işçi ve Işsverenin Suçu Bildirme Yükümlülükleri

\section{CRIME AND OBLIGATION TO REPORT THE CRIME IN THE CONTEXT OF TERMINATION FOR JUST CAUSE}

\section{Abstract}

In the Labour Code, some crimes have been accepted direct as a just cause in terms of termination of employment contract. In addition, many situations and behaviours listed in the provisions of the just cause, which is not explicitly involved in a crime, may also be covered by a crime in the Turkish Criminal

Adana Alparslan Türkeş Bilim ve Teknoloji Üniversitesi, Siyasal Bilgiler Fakültesi, Siyaset Bilimi ve Kamu Yönetimi Bölümü, Hukuk Bilimleri Anabilim Dalı (e-posta: shafizoglu@atu.edu.tr / silahafizoglu@hotmail.com) ORCID: https://orcid.org/00000002-5486-9014 (Makalenin Geliş Tarihi: 01.07.2020) (Makale Gönderilme Tarihi: 02.07.2020/Makale Kabul Tarihi: 27.11.2020) 
Code. Considering the binding effect of case determination in criminal procedure and especially parties of employment contract's obligations to report the crime, just causes in art. 24 and art. 25 of Labour Code need to be examined in the context of crime.

\section{Keywords}

Crimes As a Just Cause, Termination of Employment Contract For Just Cause, Non-compliance With the Rules of Morality and Goodwill and the Like, Crimes of not Informing a Crime, Obligation to Report the Crime in the Context of Employment Contract, Obligations to Report the Crime of Employee and Employer 


\section{GİRIŞ}

İş Kanunu ${ }^{1}$ m. 24 ve m. $25^{\prime}$ de iş sözleşmesinin her iki tarafının başvurabileceği haklı nedenle fesih halleri ayrı olarak düzenlenmiştir. Burada çeşitli suçlar açıkça haklı neden olarak kabul edilmiş; ama bunun yanı sıra, suç niteliği vurgulanmasa da nitelikleri suçlara karşıllı gelebilecek eylemler de haklı neden olarak sayılmıştır.

Çalışmamızda işverenin ve işçilerinin işlediği suçların, haklı nedenle feshe imkân verdiği kanun hükümleri tek tek incelenecektir. Haklı nedenler esas olarak iş hukuku açısından ele alınacak, ancak ceza hukuku ile de bağlantı kurulmaya çalışılacaktır. Türk Ceza Kanunu'ndaki hükümlere göre, haklı neden teşkil edecek durum ve davranışların hangi suçlara karşılık gelebileceği değerlendirilecek; ancak suçun ayrıntılı olarak maddi ve manevi unsurlarına, haklı nedenin teşebbüs, bileşik suç, zincirleme suç ya da fikri içtima bakımından incelenmesine ceza ve ceza muhakemesi hukuku alanının ayrı çalışma konuları olacaklarından makalemizde yer verilmeyecektir.

Haklı nedenle feshin geçerliliği için ceza ve ceza muhakemesi hukuku ile doğrudan bağlantılı konularda dahi (hırsızlığın haklı neden olarak kabul edilmesi gibi) esas olarak bir ceza mahkemesi kararı aranmamıştır. $\mathrm{Bu}$ sebeple, iş mahkemelerindeki haklı nedenle feshin konu edildiği davalarda $\mathrm{da}$, temel kural olan "ceza mahkemesi kararlarının hukuk mahkemelerini bağlamaması" geçerli olacaktır. Ancak temel kuralın istisnasından dolayı, suç teşkil eden ya da edebilecek haklı nedenleri, iki hukuk dalı arasında bağlantı kurarak incelemek yerinde olacaktır. Ayrıca İş Kanunu'nda haklı neden sayılan eylemlerin ceza yargılaması bakımından suç teşkil etmesi gerekmese de, bu kavram ve olgular ceza hukukuna ait terimler olduğunda ne anlama geldiği ceza hukukundan bağımsız belirlenemeyecektir.

Haklı nedenle feshin suç bakımından ele alınmasındaki en önemli husus ise suçu bildirmeme suçları sonucu işçi ve işverenin yerine getirmesi gereken suçu bildirme yükümlülügüüür. Çünkü haklı neden teşkil edebilecek bir durum ve davranış aynı zamanda suç niteliği taşıyorsa kural olarak işçi ya da işverenin suçu bildirme yükümlülüğü doğacak ve diğer taraftan bu bildirme yükümlülüğü, eylem açıkça haklı neden olarak düzenlenmese dahi kişiyi iş sözleşmesini derhal feshetmeye zorlayabilecektir. 


\section{HAKLI NEDENLE FESİHLERDE CEZA MAHKEMESI KARARI GEREKLILIIĞí VE CEZA YARGILAMASININ İŞ MAHKEMESI KARARLARINA ETKISI}

Hem işçinin hem işverenin iş sözleşmesini feshinde Türk Ceza Kanunu ${ }^{2}$ bakımından suç teşkil edebilecek eylemler haklı neden olarak kabul edilmiştir. Ancak bu durum, haklı neden sayılan davranışların suç niteliği taşımasını ${ }^{3}$, eğer bir suç teşkil ediyorsa da onun ceza yargılamasıyla tespit edilmiş ve bir mahkûmiyet verilmiş olmasını gerektirmez ${ }^{4}$.

Çünkü İş Kanunu'nda, hırsızlık vb. suçların işlenmesi açıkça haklı neden sayılmışsa da bir ceza mahkûmiyeti şartı aranmamıştır. Zaten Türk Borçlar Kanunu $(\mathrm{TBK})^{5}$ m. 74 uyarınca kural olarak ceza mahkemesi kararlarının iş mahkemeleri için (genel anlamıyla hukuk mahkemeleri için) bağlayıcı olmaması ${ }^{6}$, ceza mahkûmiyeti şartının aranmamasını desteklemektedir.

R.G. Tarih: 12.10.2004 R.G. Say1: 25611

3 Tunçomağ, Kenan/Centel, Tankut: İş Hukukunun Esasları, Yenilenmiş ve Gözden Geçirilmiş 8. Bask1, Beta Yayıncılık, İstanbul, Eylül 2016, s. 219, 223, 225, 226; Çelik, Nuri/Caniklioğlu, Nurşen/ Canbolat, Talat: İş Hukuku Dersleri, Yenilenmiş 31. Bası, Beta Yayıncılık, İstanbul, Eylül, 2018, s. 296, 579; Demir, Fevzi: İş Hukuku ve Uygulamas1, 11. Bask1, Albi Yayınları, İzmir, Eylül 2018, s. 408; Eyrenci, Öner/Taşkent, Savaş/Ulucan, Devrim: Bireysel İş Hukuku, 9. Baskı, Beta Yayıncılık, İstanbul, Mart 2019, s. 245; Narmanlığlu, Ünal: İş Hukuku Ferdi İş İlişkileri I, Beta Yayıncılık, 5. Bas1, İstanbul, Aralık 2014, s. 425427 429, 444; Süzek, Sarper: İş Hukuku, Yenilenmiş 18. Bask1, Beta Yayınc1lı, İstanbul, Eylül 2019, s. 672, 673, 674, 684, 685; Mollamahmutoğlu, Hamdi/Astarlı, Muhittin/Baysal, Ulaş: İş Hukuku Ders Kitabı, Cilt 1: Bireysel İş Hukuku, Gözden Geçirilmiş 3. Baskı, Lykeion Yayınları, Ankara, Eylül 2019, s. 230, 231, 232, 240; Odaman, Serkan: İşverenin Hizmet Sözleşmesini Ahlak ve İyiniyet Kuralları ve Benzerlerine Aykırılık Nedeniyle Fesih Hakkı, Ankara, 2003, (Ahlak ve İyiniyet Kuralları ve Benzerleri), s. 148; Ergin, Hediye: "İşçinin İşyerinde Çalışan Diğer Bir İşçiye Sataşması Nedeniyle İş Sözleşmesinin İşveren Tarafından Feshi", Sicil İHD, Y11: 2015, S.34, ss. 71-87, s. 75; Öktem Songu, Sezgi: "Bir Haklı Fesih Sebebi Olarak 'Sataşma”, Sicil İHD, Yı1: 2018, S.39, ss. 113-145, (Sataşma), s. 121; Arslan Durmuş, Seda: İşverenin Haklı Nedenle Fesih Hakkı, Oniki Levha Yayıncılık, İstanbul, 2012, s. 87; Yamakoğlu, Efe: Bilişim Teknolojilerinin Kullanımının İş Sözleşmesi Taraflarının Fesih Hakkına Etkisi, Onikilevha Yayıncılık, İstanbul, Ocak 2020, s. 137. Bu yönde Yargıtay kararı için bkz.“...davacının eyleminin hırsızlık olarak kabul edilmese bile işverenin iş̧̧iye olan güvenini ortadan kaldıracak nitelikte doğruluk ve bağllı̆̆a uymayan davranıs olarak kabulü gerekir...”, Y. 22. HD. 10.04.2012, 2011/ 13991 E., 2012/6817 K.., (www.kazanci.com, E.T.:25.06.2020).

Mollamahmutoğlu/Astarlı/Baysal, s. 230; Narmanlığlu, s. 425, 429.

$5 \quad$ R.G. Tarih: 04.02.2011 R.G. Say1: 27836

6 Bu kuralın nedenleri ve ayrıntılı bilgi için bkz. Dişel, Buse: "Ceza Mahkemesinin Mahkûmiyet Kararının Hukuk Mahkemesi Kararına Etkisi ve Bekletici Sorun Yapılması", Prof. Dr. Bilge Umar'a Armağan I, İzmir, 2010, DEÜHFD, Yı1: 2009, C.11, Özel Say1, ss. 183-224; Kapancı, Kadir Berk: "Ceza Mahkemesi Kararlarının Hukuk Mahkemesi 
$\mathrm{Bu}$ doğrultuda haklı nedenle fesih için, ceza yargılaması sonucunu bekleme zorunluluğu olmadığ gibi suçtan beraat edilmesi de otomatik olarak fesih hakkını ortadan kaldırmayacaktır ${ }^{7}$. Benzer şekilde mağdurun şikâyetten vazgeçmesi, haklı neden teşkil edip etmeme durumunu etkilemeyecektir ${ }^{8}$.

Ancak hukuk hâkiminin ceza yargılaması ve sonunda verilen kararlardan bağımsızlığı sınırsız değildir". Hukuka duyulan güvenin korunması ve yeknesaklığın sağlanması için "ceza mahkemesinin mahkûmiyet kararları" ve "ceza yargılamasında tespit edilen maddi olgular"la iş yargıcı bağlı olacaktır $^{10}$. Böylece ceza mahkemesinde bir olayın varlığı ya da yokluğu konusunda kesinleşmiş kabul varken, aynı husus yeniden tartışılamayacaktır. Diğer bir ifadeyle, Yargıtay'ın da belirttiği üzere maddi olguların ve yasak fiillerin varlığını belirleyen ceza mahkemesi kararları, taraflar yönünden kesin delil niteliğini taşıyacaktır ${ }^{11}$.

Öncelikle maddi olgu tespitinin söz konusu olması için bakış açısına göre değişen (göreceli) bir durumun olmaması gerekmektedir. Zaten TBK m.

Kararlarına Etkisi (TBK m. 74)", İnönü Üniversitesi Hukuk Fakültesi Dergisi, Yı1: 2016, C.7, S.1, ss. 511-552.

7 Süzek, s. 673, 674; Mollamahmutoğlu/Astarlı/Baysal, s. 240; Senyen Kaplan, Emine Tuncay: Bireysel İş Hukuku, Yenilenmiş 8. Baskı, Gazi Kitabevi, Ankara, Eylül 2017, (İş Hukuku), s. 285; Savaş, F. Burcu, İş Sözleşmesinin İşveren Tarafından Haklı Nedenle Feshi, Beta Yayıncılık, 2012, s. 82, 91; Öktem Songu, Sataşma, 121, TUNÇOMAĞ ve CENTEL de haklı nedenle sözleşmeyi feshedebilmek için ceza kovuşturmasına başlanmış ya da mahkûmiyet kararı verilmiş olması gerekmediği ancak, suçun işçi tarafından işlenmediğine ilişkin beraat kararı ile iş mahkemesinin bağlı olacağını belirtmektedir, (Tunçomağ/Centel, s. 227) Fakat bu noktada beraat kararının içeriği önem taşımaktadır. Örneğin, beraat kararı delil yetersizliğinden verilmişse iş mahkemesinin bu kararla bağlı olduğu söylenemeyecektir. Hırsızlık suçuna ilişkin kararın kesinleşmemesine, hatta işçinin ilgili suçtan beraat etmesine rağmen haklı nedenle feshin onaylandığı karar için bkz. Y. 9. HD., 02.07.1997, 1997/648 E., 1997/6556 K., (www.kazanci.com.tr, E.T.: 25.06.2020).

$8 \quad$ Bkz. Y. 9. HD., 11.09.2013, 2013/6458 E., 2013/22020 K., (www.legalbank.net, E.T.: 25.06.2020).

9 Y.4. HD., 16.06.2016, 2015/7085 E., 2016/8005 K., (www.kazanci.com, E.T.: 14.09.2020).

10 Süzek, s. 674; Öktem Songu, Sataşma, s. 121-122; Yamakoğlu, s. 137. Bkz. Y. 9. HD., 06.06.1994, 1994/3809 E., 1994/8607 K.; Y. 21. HD., 28.03.2017, 2016/5673 E., 2017/ 2484K.;Y.10. HD., 18.12.2019, 2019/2612 E., 2019/10045 K., (www.kazanci.com, E.T.:14.09.2020).

11 Süzek, s. 674. Y. HGK., 10.01.1975, 1971/406 E., 1975/1 K., Y. HGK. , 23.01.1985, 1983/10-372 E., 1985/21 K. Y. HGK., 09.04.2014, 2013/4-1008, 2014/490, Y. HGK. 06.06.2018, 2017/15-248 E., 2018/1175K., Y. HGK., 31.01.2019 2017/11-55 E., 2019/ 43K.; Ankara, BAM, 25. HD., 05.10.2017, 2017/966 E., 2017/994; Ayrica bkz. Samsun, BAM, 2. HD., 22.06.2017, 2017/429 E., 2017/477 K., (www.kazanci.com, E.T.: 14.09.2020). 
74'de kusurun olup olmadığı, kusurun değerlendirilmesi ve zararın belirlenmesine ilişkin kararların hukuk hâkimini bağlamayacağı açıkça belirtilmiştir. Ayrıca Yargıtay, hukuk hâkiminin ceza mahkemesi kararındaki maddi olgularla bağl1lı̆̆ının ölçüsünün, "söz konusu bir durumun varlığ1 ya da yokluğunun veya davranışın gerçekleştirildiği ya da gerçekleştirilmediğinin kesin olarak delillerle tespit edilip edilmediği" olduğunu ifade etmiştir ${ }^{12}$. Bu doğrultuda işçinin haklı neden teşkil eden eyleminin gerçekleştiği ceza mahkemesi kararı ile sabit olursa, ilgili davranış sebebiyle işçi ceza alsın almasın, haklı nedenle feshe karşı açılmış bir davada iş hâkiminin bunu dikkate alması gerekecektir. Çünkü ortada varlığı hukuken kanıtlanmış bakış açısına göre değişmeyecek bir durum, bir maddi olgu tespiti vardır ve bunun bir başka yargı kararıyla aksinin kabulü hem madden hem de hukuken mümkün olamayacaktır. Yargıtay da bir kararında fail-eylem ilişkisinin maddi bir olgu olduğunu ve iş mahkemesinin bunu dikkate alması gerektiğini açıkça ifade etmiştir ${ }^{13}$. Bir başka örnek verirsek, iş uyuşmazlığında bir belgenin sahteliği ile ilgili bir durum varsa ve ceza yargılamasında o belgenin sahte ya da gerçek olduğu tespit edildiyse, iş mahkemesi hâkimi bunu göz ardı edemeyecektir ${ }^{14}$.

"Ceza mahkemesi kararlarının hukuk mahkemeleri için bağlayıcı olmaması" genel kuralı doğrultusunda, iş mahkemesi hâkiminin ceza yargılamasını bekletici mesele yapma zorunluluğu da yoktur. Ama devam etmekte olan kovuşturma veya soruşturma sürecindeki olgular, elindeki somut olayla ilgiliyse ve olay zaten açıkça ortada değilse, "dava taraflarının menfaatleri" ve "iş yargılamasında hâkim olan çabukluk ilkesi" "ni de göz önünde tutarak, hâkimin cezai süreci bekletici mesele yapması gerekebilir. Hatta soruşturma ve kovuşturma konusu olan olay, doğrudan kendi davasının esasını teşkil ediyorsa, hukukta yeknesaklığın sağlanması ve hukuka duyulan güve-

12 Y. 9.HD., 16.09.2013, 2011/22011 E., 2013/22543 K., (www.kazanci.com, E.T.: 14.09.2020).

13 Y. 9.HD., 6.6.2011, 2011/26212 E., 2011/16791 K., (www.kazanci.com, E.T.: 23.09.2020).

14 Aslında bu sonuca HMK(R.G.Tarihi: 04.02.2011 R.G.Sayı: 27836) m. 214/II'den yola çıkarak da ulaşılabilecektir. Çünkü HMK m. 214,'de, ceza mahkemesinde sahte belge düzenlenmesi iddiası karşısında, düzenleyen kişi hakkında ceza verilmesine yer olmadığı ya da beraat kararı verilmiş olmasının, hukuk mahkemesinin belgenin sahteliğini incelemesini engellemeyeceği belirtilmiş; ama belgenin sahte olmadığına dair hukuk mahkemesince verilen kesin bir karar varsa, aynı belge hakkında ceza mahkemesinde sahtelik iddiasının dinlenemeyeceği de ifade edilmiştir.

15 İş Yargılamasında hâkim olan ilkeler için bkz. Kar, Bektaş: "İş Yargılamasında Hâkim Olan İlkeler", Polat SOYER'e Armağan, DEÜHFD, Yı1: 2013, C.15, Özel Say1, 2014, ss. $869-882$. 
nin zedelenmemesi açısından bekletici mesele yapmak adeta bir zorunluluk teşkil edecektir. Çünkü yukarıda yer verdiğimiz ve Yargıtay'ın da belirttiği üzere ceza mahkemesindeki bir maddi olgunun varlığı ya da yokluğu konusundaki kesinleşmiş kabul hukuk mahkemesinde yeniden tartışılamayacaktır; bu sebeple maddi olguların nasıl gerçekleştiğini tespit edebilmek için ceza davasının sonucunun beklenilmesi gereklidir ${ }^{16}$. Bölge Adliye Mahkemeleri de hukuk mahkemesinin ceza mahkemesi kararını beklemesi gerektiği yönünde kararlar vermiştir ${ }^{17}$.

Açıklamalar 1şığında, haklı neden kapsamında bir mahkûmiyet aranmadığından, somut olaydaki hareketlerin suç niteliği taşıyıp taşımadığının tespitinin iş hukuku bakımından hiçbir önemi olmadığı ve haklı nedenlerin ceza kanundaki düzenlemeler bakımından ele alınması gerekmediği düşünülebilir. Ancak ceza mahkemesi kararı ile bağlı olunmasa da, iş mahkemesi hâkimi elindeki dava ile ilgili ceza yargılamasındaki maddi olgu tespitlerini dikkate almak zorundadır. Ayrıca haklı neden düzenlemelerinde geçen hırsızlık, cinsel taciz vb. kavramlar ceza hukukuna aittir ve esasen ceza hukuku alanına ait olan ifade ve olguların ne anlama geldiğini ceza hukuku ve ilgili mevzuat bağlamında irdelemek gereklidir. Buna ek olarak işçinin haklı neden teşkil edecek bir davranışının aynı zamanda suç olup olmadığı işçi ve işverenin suçu bildirme yükümlülükleri bakımından da önem arz edecektir. $\mathrm{Bu}$ açıdan incelememizde suçu bildirmeme suçlarına da yer vereceğiz.

\section{IŞ̧ SÖZLEŞMESI BAKIMINDAN SUÇU BÍLDİRME YÜKÜMLÜLÜĞ̈̈}

\section{A. Suçu Bildirmeme Suçu ${ }^{18}$}

TCK m. 278'de suçu bildirmeme suçu düzenlenmiştir. Bu maddeye göre işlenmekte olan bir suçu yetkili makamlara bildirmeyen ${ }^{19}$ kişi suçu bildirmeme suçu işlemiş olur ve hapis cezası ile cezalandırılır. Bu suç, sadece devam eden suçların bildirilmemesi durumunda gerçekleşmez. İşle-

16 Y. HGK., 31.01.2019, 2017/11-55 E., 2019/43K., (www.kazanci.com.tr, E.T.: 25.06.2020).

17 Samsun, BAM, 2. HD., 22.06.2017, 2017/429 E., 2017/477 K.; İstanbul, BAM, 9. HD., 12.11.2019, 2017/2172E., 2019/3773 K. Dava konusu somut olay bakımından bekletici mesele yapılmasına gerek olmadığı yönünde ise bkz. Antalya, BAM, 6. HD., 02.05.2019, 2018/867 E., 2019/534 K. (www.kazanci.com, E.T.:14.09.2020).

18 Elbette aşağıda açıklayacağımız suçu bildirmeme suçu doğrultusunda işverenin ve işçinin genel anlamda bir hukuk süjesi olarak suçu bildirme yükümlülüğü bulunmaktadır. Ancak çalışmada iş ilişkisi bağlamında yapılması gereken bildirimler ele alınmıştır. 
nip sona eren ama suçun neticelerinin sinırlandırılması hala mümkün olan suçların da bildirilmemesi "suçu bildirmeme" suçu teşkil edecektir. TCK m. 279 ve m. 280 'de ise sırasıyla kamu görevlisinin ve sağlık mesleği mensuplarının suçu bildirmemesi ayrı olarak düzenlenmiştir. Bu iki düzenleme, "suçun failleri", "devam etsin etmesin işlenen tüm suçları kapsaması" ve "bir cezasızlık nedeni düzenlenmemiş olması" bakımından TCK m. 278'den farklıdır.

Suçu bildirmeme suçunun faili herkes olabilir ${ }^{20}$. Doğal olarak işçi ve işverenin de bu suçu işlemesi mümkündür. İşveren de işçi de düzenleme uyarınca suçu bildirme yükümlülüğü altında olacak ve bu yükümlülük iş ilişkisini kaçınılmaz olarak etkileyecektir. Bu doğrultuda, inceleme konumuz olan haklı neden teşkil edecek suçlarla karşılaşıldığında da işçi ve işverenin bildirim yükümlülükleri doğabilecektir.

Toplumların demokrasiyi benimsemesiyle, hukuk sistemlerindeki devletin özel yaşama müdahalesi gitgide sınırlanmıştır ${ }^{21}$. Liberal devletlerin, vatandaşları suçu kovuşturma işine bulaştırmaktan kaçındıkları da belirtilmiştir ${ }^{22}$. Çünkü suçu bildirmeme suçunda korunan "kamu barıșı" daha genel bir ifadeyle söylersek "korunmaya çalışılan 'kamu yararı' "23 ile kişilerin "anayasal hak ve özgürlükleri (özel hayatın gizliliği, kişisel verilerinin gizliliği vb.)" arasında bir yarış söz konusudur. Bu sebeple suçla korunmak istenen ve suç düzenlemesi karşında zedelenebilecek menfaatlerin değerlendirilmesinin iyi yapılması, bir denge sağlanabilmesi açısından önemlidir.

Tezcan, Durmuş/ Erdem, Mustafa Ruhan/Önok, R. Murat: Teorik ve Pratik Ceza Özel Hukuku, Güncellenmiş 17. Bask1, Seçkin Yayıncılık, Ankara 2019, s. 1264; Ünver, Yener: İftira, Suç Uydurma, Suç Üstlenme, Yalan Tanıklık ve Bilirkişilik, İnfaz Kurumlarından Kaçma (TCK'da Düzenlenen Adliyeye Karşı Suçlar), 4. Baskı, Seçkin Yayıncılık, Ankara, Haziran 2016, s. 285; Erdem, Mustafa Ruhan: "Suçu Bildirmeme Suçu (TCK m. 278)", TBB Dergisi, Y11: 2009, S.80, ss. 105-120, s. 108; Alp, Mustafa, Çalışanın İşvereni ve İş Arkadaşlarını İhbar Etmesi (Whistleblowing), Beta Yayıncılık, İstanbul, Aralık 2013, (Whistleblowing), s. 74; Hafızoğulları, Zeki/Acar, Bülent Hayri: "Suçu Bildirmeme Suçları", Başkent Üniversitesi Hukuk Fakültesi Dergisi, Ocak 2016, C.2, S.1, ss. 179-198, s. 185; Işık, Göksu: "Hukuki Güvenlik İlkesi Bağlamında Suçu Bildirmeme Suçu", Beykent Üniversitesi Hukuk Fakültesi Dergisi, C.3, S.7, Aralık 2017, ss. 163-187, s. 178.

21 Döner, İsa: "Suçu Bildirmeme Suçu (TCK m. 278)", AÜEHFD, Y11:2005, C.: IX, S. 34, ss. 63-94, s.70; Işıık, s. 166.

22 Tezcan/Erdem/Önok, s. 1262, Erdem, s. 106-107; Alp, Whistleblowing, s. 75.

23 Hafızoğulları/Acar, s. 186. Teorik açıdan suçla korunan hukuki yararın ne olduğu doktrinde tartışmalı olsa da (bkz. Tezcan/Erdem/Önok, s. 1262-1264, Ünver, s. 283284; Erdem, s. 106; Alp, Whistleblowing, s. 73-74; Işık, s. 177-178) madde gerekçesinde belirtilen "toplumsal barışın korunması", "suçların cezalandırılması ve takibi" amaçları karşısında suçun kamusal bir yarar taşıdığı açıktır. 
Hatta işçinin veya işverenin her suçta (cezasızlık nedeni kapsamına girmediği sürece) ihbara mecbur bırakılması aşırı bulunduğundan doktrinde eleştirilmiştir ${ }^{24}$. Hak ve menfaatler arasındaki dengenin bir ölçüde de olsa sağlanması bakımından, TCK m. 278/IV son fikrasında tanıklıktan çekinebilecekler $^{25}$ (Ceza Muhakemesi Kanunu ${ }^{26}$ m. 45/I ${ }^{27}$ ve m. $46^{28}$ ) için cezaya hükmolunamayacağına ${ }^{29}$ yer verilmiştir ${ }^{30}$.

İş Hukuku bakımından CMK m. 46 değerlendirildiğinde, iş ilişkisi sebebiyle işçi ve işverenlerin bu kapsamda olmayacağı açıktır. CMK m. 46/I-a uyarınca işçi avukatlar ve CMK m. 46/I-b'ye göre iş sözleşmesiyle çalışan sağlık mensupları bakımından ${ }^{31}$ bildirme yükümlülüğün bir istisnasının söz

Alp, Whistleblowing, s. 76.

F1kra, suçu önleme yükümlülügünden dolayı ceza sorumluluğuna ilişkin hükümleri saklı tutmuştur.

R.G. Tarih: 17.12.2004 R.G. Say1: 25673

CMK m. 45/I: "Aşağıdaki kimseler tanıklıktan çekinebilir: a) Şüpheli veya sanı̆̆ın nişanlısı. b) Evlilik bağı kalmasa bile şüpheli veya sanığın eşi. c) Şüpheli veya sanığın kan hisımlığından veya kayın hisımlı̆̆ından üstsoy veya altsoyu. d) Şüpheli veya sanı̆̆ın üçüncü derece dahil kan veya ikinci derece dahil kayın hisımlart. e) Şüpheli veya sanıkla aralarında evlâtlık bağı bulunanlar."

CMK m. 46: "(1)Meslekleri ve sürekli uğraşıları sebebiyle tanıklıktan çekinebilecekler ile çekinme konu ve koşulları şunlardır: a) Avukatlar veya stajyerleri veya yardımcılarının, bu sifatları dolayısıyla veya yüklendikleri yargı görevi sebebiyle ögrendikleri bilgiler. b) Hekimler, diş hekimleri, eczacılar, ebeler ve bunların yardımcıları ve diğer bütün tıp meslek veya sanatları mensuplarının, bu sifatları dolayısiyla hastalarl ve bunların yakınları hakkında ögrrendikleri bilgiler. c) Mali işlerde görevlendirilmiş müşavirler ve noterlerin bu sıfatları dolayısıyla hizmet verdikleri kişiler hakkında ögrrendikleri bilgiler. (2) Yukarıdaki fikranın (a) bendinde belirtilenler dışında kalan kişiler, ilgilinin rızasının varlı̆̆ halinde, tanıklıktan çekinemez."

Kanunun lafzından da anlaşıldığı üzere doktrinde buradaki istisnai durumun bir hukuka uygunluk değil kişisel bir cezasızlık nedeni olduğu belirtilmektedir, (Tezcan/Erdem/ Önok, s. 1266, Kolcu, Selahattin, Suçu Bildirmeme Suçu, Seçkin Yayıncılık, Ankara, Kasım 2016, s. 94).

Suçu bildirmeme suçlarına çalışmamızda yer versek de TCK m. 278 suçu bildirmeme, TCK m. 279 kamu görevlisinin suçu bildirmemesi ve TCK m. 280 sağlık mesleği mensuplarının suçu bildirmemesi ayrı ayrı birer çalışma konusu olduğundan burada tüm ayrıntılarıyla ele alınamayacak, sadece çeşitli tespitler yapmakla yetinilecektir. Ayrıntılı bilgi için bkz. Tezcan/Erdem/Önok, s. 1273-1279; Ünver, s. 282-358; Törenli Çakıroğlu, Maral: "Hekimin Borçlarından Özel Olarak Sır Saklama Borcu”, DEÜHFD, Y1l: 2010, C.12 S.2, ss. 159-181; Kolcu, Selahattin, Suçu Bildirmeme Suçu, Seçkin Yayıncılık, Ankara, Kasım 2016; Giyik, Abdülbaki: "Hekimin Sır Saklama Yükümlülüğü ile Suçu Bildirme Yükümlülügüü ve Bu Yükümlülüklerin Çatışması”, Erciyes Üniversitesi Hukuk Fakültesi Dergisi, Cilt: IX, Sayı: 2, 2014, ss.175-214; Yağlıdere, Umut Emre: "Sağlık Mesleği Mensuplarının Suçu Bildirmemesi Suçu (Türk Ceza Kanunu m. 280), Kadir Has Üniversitesi Hukuk Fakültesi Dergisi, C.6, S.1, Haziran 2018, ss. 59-79.

Bkz. II. C. İşçinin Suçu Bildirme Yükümlülüğü 
konusu olup olmayacağ irdelenebilir. Ama herhangi bir başka neden olmadıkça ${ }^{32}$ sadece işçinin sır saklama ve işverenin ise işçinin kişisel verilerini koruma yükümlülüğü, Ceza Muhakemesi Kanunu kapsamında tanıklıktan çekinme hakkı sağlamadığından kural olarak hem işçi hem işverenin bildirim yükümlülüğü vardır.

TCK m. 278 herhangi bir ayrım yapmadığından, ağırlığı, işleniş şekli (kast ya da taksir) ve nerede düzenlendiği fark etmeksizin (TCK'da düzenlenmiş olması zorunluluğu yoktur) her suç bakımından bildirim yükümlülüğü doğacaktır³ . Ama eylemin suç teşkil etmesi önemlidir. Başka düzenlemelerden dolayı özel bir bildirim yükümlülüğü bulunmuyorsa, TCK m. 278 uyarınca kabahatler ya da disiplin cezasını gerektiren eylemlerin bildirilmesi zorunluluğu yoktur ${ }^{34}$.

Ayrıca doktrinde "genel nitelikli suçu bildirmeme suçu" olarak nitelendirilen ${ }^{35}$ TCK m. 284'de düzenlenen "suç delillerini bildirmeme" suçuna da yer vermemiz uygun olacaktır. Maddeye göre, işlenmiş olan bir suça ilişkin delil ve eserlerin başkaları tarafından saklandığı yeri bildiği halde yetkili makamlara bildirmeyen kimse, bir yıla kadar hapis cezası ile cezalandırılır. Bununla birlikte TCK m. 278 düzenlemesine benzer şekilde, üstsoy, altsoy, eş veya kardeş tarafından işlenen suçlar bakımından suç delil ve eserlerine ilişkin bildirim yapılmazsa cezaya hükmolunmayacaktır.

TCK m. 284'ün işveren ve işçiyi zorda bırakabilecek suçu bildirme yükümlügünün etki alanını genişlettiğini söyleyebiliriz. Çünkü TCK m. 279 ve 280'nin uygulama alanı söz konusu değilse, TCK m. 278 uyarınca bildirim

32 Bkz. II B. İşverenin Suçu Bildirme Yükümlülüğü, II. C. İşçinin Suçu Bildirme Yükümlülüğü

33 Tezcan/Erdem/Önok, s. 1267. Takibi şikâyete bağlı suçlar bakımından suçu bildirmeme suçu söz konusu olup olmayacağı bir başka ifadeyle bu konuda bir bildirim yükümlülüğü olup olmadığı tartışmalıdır. Bir görüş bu suçların yükümlülük kapsamında olduğunu savunurken [Hafizoğullari/Acar, s. 187 (Bununla birlikte HAFIZOĞULLARI ve ACAR TCK m. 280 kapsamına da takibi şikâyete bağlı suçların gireceğini belirtmiş ama TCK m. 279 bakımından kapsam dışı tutmuştur, s. 192, 197)], TBMM taksirli ve takibi şikâyete bağlı suçların kapsam dışı bırakılması önerisi kabul edilmediğinden aksi sonucu da çıkarmak mümkündür (Bkz. Ünver, s. 290-291; Erdem, s. 110 dpn. 24; Alp, Whistleblowing, ss. 74-75). Ama bizim açımızdan önemli olan iş̧̧i ve işverenin genel anlamda bir bildirim yükümlülüğü altında olup olmadığı ve bu yüzden iş ilişkisinin, özellikle iş sözleşmesinin sona ermesi bakımından etkilenmesidir. Bu sebeple somut olayda işçinin bir suçu bildirmemiş olması sebebiyle suçu işlemiş olup olmayacağının tespiti ceza hukukunun konusudur ve bu tartışmalı duruma çalışmamızda kısaca değinmekle yetinilmiştir. Konu ile ilgili ayrıntılı bilgi için bkz. Işsk, s. 174-175. 
yükümlülüğü sadece "devam eden ya da sona erse de suçun neticelerinin sınırlandırılması hala mümkün olan durumlar" için doğacaktır. Ancak TCK m. 284'deki suç delillerini bildirmeme suçu ile işçi ya da işveren kural olarak karşılaştığı sona ersin ermesin ya da etkisi bitsin bitmesin tüm suçlarla ilgili bir bildirim yapmak zorunda olabilecektir.

\section{B. İşverenin Suçu Bildirme Yükümlülüğ̈̈}

TCK m. 278 doğrultusunda işverenin işyerinde cereyan eden veya işyeri dışında da olsa işçisi tarafından işlendiğini öğrendiği suçları yetkili makama bildirmesi gerekir.

Çalışmamız bakımından bu konuda değerlendireceğimiz ilk husus, işverenin bir suça dayanarak işçinin sözleşmesini feshetmesinin suçu bildirme yükümlülüğünün yerine getirilmesi olarak kabul edilip edilmeyeceğidir. İşten ayrılış bildirgesinde, ayrılma nedeni bir kod olarak belirtildiğinden bu belge sadece feshin İşK. m. 25/II'ye dayandırıldığını gösterecektir. Bunun için işten ayrılış bildirgesi ve dolayısıyla işverenin iş sözleşmesini feshetmesi suçu bildirme yükümlülüğü için yeterli kabul edilemeyecektir. Zaten, işçinin daha sonra işe iade davası açmasını ve işçiyle husumet yaşanmasını önlemek adına ya da işsizlik ödeneği alınmasına mani olmamak için işveren farklı bir sona erme gerekçesi de gösterilebildiğinden, bildirim yükümlülüğünün gerçekleştiğini kabul etmek mümkün olmaz.

Haklı nedenle feshin işe iade davasına konu edilmesiyle de, her ne kadar bu şekilde suç adli makamlara dolaylı olarak yansısa da, işverenin yükümlülüğünü yerine getirmiş olduğu söylenemeyecektir. Zaten işe iade davasında davayı açan işçi olacaktır.

Burada bildirimin, suç işleyen ya da daha doğrusu suç işlediği iddia edilen (henüz bir mahkeme kararı olmadığından bu şekilde ifade etmek uygun olacaktır) kişiye karşı gözetme borcu ihlali teşkil edip etmeyeceği sorusu da akla gelebilir.

Genel anlamda işçiyi gözetme borcu kapsamında olan ve konumuz bakımından inceleyeceğimiz yükümlülük, işçinin kişiliğinin gözetilmesidir. Gözetme borcu uyarınca işveren, işçinin kişiliğini korumak ve sayg1 göstermekle yükümlüdür. Bu doğrultuda işveren, işçinin kişiliğini oluşturan maddi unsurların yanı sıra manevi unsurları da gözetmelidir. İşveren işçinin öncelikle yaşamını, sağlı̆̆ını ve beden bütünlüğünü, ama bunların yanı sıra ruhsal 
bütünlüğünü, şeref ve onurunu, hem kişisel hem mesleki saygınlığını, ahlaki değerlerini ve özel yaşam alanını korumalıdır ${ }^{36}$.

Görüldüğü üzere, iş sözleşmesinin kişisel niteliğinden dolayı ortaya çıkan ve işçinin sadakat borcunun karşılığını teşkil eden bu gözetme borcunun kapsamı geniştir ve de kanunda sınırları açıkça çizilmemiştir. Ama bu durum, korumanın sinırsız olduğu anlamına gelmez. Gözetme borcunun kapsam ve sınırları, işverenin diğer yükümlülükleri (Ör: TCK m. 278'den doğan suçu bildirme yükümlülüğü), işçilerin diğer hak ve özgürlüklerini düzenleyen kanun hükümleri, bir başka işçinin kişiliğinin korunması ve dürüstlük kuralı (Türk Medeni Kanunu ${ }^{37}$ - TMK m. 2) ile çizilmektedir ${ }^{38}$.

İş ilişkisinden doğan işverenin bu borcuna Türk Borçlar Kanunu'nda açıkça yer verilmiştir. TBK m. 417/'I de işverenin, hizmet ilişkisinde işçinin kişiliğini korumak, işçiye sayg1 göstermek, işyerinde dürüstlük ilkesine uygun şekilde bir düzeni sağlamak, özellikle işçilerin psikolojik ve cinsel tacize uğramamaları ve bu tür tacizlere uğramış olanların daha fazla zarar görmemeleri için gerekli önlemleri almak zorunda olduğu belirtilmiştir.

TBK m. 417'deki bu düzenleme karşısında başka bir dayanak ve açıklamaya gerek olmaksızın suç bildiriminde bulunmanın yükümlülük ihlali teşkil etmeyeceği anlaşılır. Yukarıda da belirttiğimiz üzere dürüstlük kuralı ve bir diğer kişinin hak ve özgürlüğü işçinin kişiliğinin korunması sınırını oluşturmaktadır. İşverenin gözetme borcu kapsamında, işçinin kişisel verilerinin korunması bakımından bir "saklama borcu" olduğu kabul edilebilirse de, düzenlemelerin açıklığı ve düzenleme olmasa da yarışan menfaatler

36 İşçinin kişiliğinin korunması ile ilgili ayrıntılı bilgi için bkz. Süzek, s. 386-396; Mollamahmutoğlu/Astarlı/Baysal, s. 184 vd.; Senyen Kaplan, Emine Tuncay: "İş Hukukunda Kişilik Haklarının Özellikle Bilgisayarda Toplanan Bilgilere Karşı Korunması", Prof. Dr. Cemal MIHÇIOĞLU'na Armağan, Ankara Üniversitesi SBF Dergisi, 1997, C.52, (Bilgisayar Bakımından İşçinin Kişilik Hakları), ss. 367-386; Senyen Kaplan, Emine Tuncay: "Mukayeseli İş Hukukunda İşçinin Kişilik Haklarının Bilgisayarda Toplanan Verilere Karşı Korunması", Kamu İş Dergisi, Yı1: 1999, S.4, ss. 367386; Aydın, Ufuk: İş Hukuku'nda İşçinin Kişilik Hakları, Anadolu Üniversitesi Yayınları, 2002; Ertürk, Şükran, İş İlişsisinde Temel Haklar, Seçkin Yayıncılık, Ankara, May1s 2002, s. 83 vd.; Centel, Tankut: “Türk Borçlar Kanunu'nda Genel Olarak İşçinin Kişiliğinin Korunması", Sicil İHD, Y11: 2011, S.24, ss. 13-18; Okur, Zeki: İş Hukuku'nda Elektronik Gözetleme, Legal Kitapevi, İstanbul, Ekim 2011, ss. 67 vd.; Öktem Songu, Sezgi: "İşçilerin İşyerinde Özel Amaçlı İnternet ve E-Posta Kullanımına İşverenin Müdahalesi Üzerine Bir Değerlendirme", Sarper SÜZEK'e Armağan, C. I, Beta Yayınc1lık, İstanbul 2011, ss. 1057-1098, s. 1061-106; Erdoğan, Canan: Kişilik Hakkı Kapsamında İşçilerin İzlenmesi ve Gözetlenmesi, Yetkin Yayınları, Ankara, 2017, s. 27-78.

37 R.G. Tarihi: 08.12 .2001 R.G. Say1: 24607

38 Süzek, s. 386. 
dengesi dikkate alındığında ("suçu işleyen işçiyi gözetme borcu", "diğer işçileri gözetme borcu", "ceza kanununda suçu bildirmemenin suç olarak düzenlemesindeki kamu yararı" arasındaki) suç bildirimiyle işverenin işçiyi gözetme borcunu ihlal etmeyeceği konusunda tartışma olmayacağını düşünüyoruz.

İşveren ile işçi arasındaki güven ilişkisine dayanılarak işverenin, avukat - müvekkil ilişkisinde geçerli olan Avukatlık Kanunu ${ }^{39}$ (Av. K.) m. 36'daki gibi bir "sır saklama" yükümlülüğü olduğunu ve "işçinin işlediği ya da işlemekte olduğu suçları adli mercilerden gizlemenin", işverenin "işçinin kişisel verilerinin korunması yükümlülüğü" kapsamına girebileceğini söylemek mümkün değildir. Çünkü "avukat-müvekkil arasındaki ilişki” ile "işçi-işveren arasındaki ilişki" birbirinden farklıdır. Kaldı ki avukatlar bakımından bile doktrinde "suçu bildirme yükümlülüğ̈̈nün sir saklamanın önüne geçeceği görüşü’ doğrultusunda sır saklama yükümlülüğünün sınırı tartışmal1$\mathrm{der}^{40}$. Bu bağlamda işçi-işveren ilişkisinde suçun bildirilmesinin önünde kanuni bir engel olduğu kabul edilemeyecektir ${ }^{41}$.

Sonuç olarak, suçun faili ya da mağduru ${ }^{42}$ kendisi değilse ve faile CMK m. 45 "tanıklıktan çekinme" kapsamına girecek şekilde yakınlığ 1 yoksa TCK m. 278 düzenlemesi istisnası oluşmadığından işverenin suçu bildirme suçundan ceza alabileceği kabul edilmelidir ${ }^{43}$.

Haklı neden olan ve suç arz edebilecek bir eylemin işverence ilgili makamlara bildirilmemesinin işverenin cezalandırılmasına yol açması ceza hukukunu ilgilendiren bir durumdur; ancak işverenin bir suç söz konusu olduğunda buna ilişkin bir bildirim/ihbar yükümlülüğü olup olmadığı iş hukuku açısından önemlidir. Çünkü böyle bir yükümlülük, "ceza alma endişesi” yle işverenin ihbarda bulunmasına ve bu ihbar karşısında iş sözleşme-

39 RG. Tarih: 7.4.1969, RG: Sayıs1: 13168

40 Bu konuda bkz. II. C. İşçinin Suçu Bildirme Yükümlülüğü dpn. 47.

41 Alp, Whistleblowing, s. 277-278.

42 Her ne kadar bu durum tanıklıktan çekinme gibi Kanunda açıç̧a düzenlenmemişse de, suçun mağduru veya suçtan zarar gören kişiye böyle bir yükümlülük verilmesinin, kişiyi bir kez daha mağdur edeceği ve bunun hukukun temel ilkelerine aykırı olacağı belirtilmiştir. Bu sebeple de Kanun'da yer verilmese de durumun uygulayıcı tarafindan resen dikkate alınması ve suçun mağduru veya zarar görenine ceza verilmemesi gerektiği kabul edilmektedir, (Tezcan/Erdem/Önok, s. 1266, Erdem, s. 109-110; Kolcu, s. 76). Ancak işlenmekte olan suçun mağdurunun veya zarar görenin de suçu bildirmeme suçu faili olabileceği aksi görüşü de vardır, (Hafızoğulları/Acar, s. 185).

43 İşverenin avukat ya da sağlık mesleği mensubu olması durumunda CMK m. 46 anlamında bir tanıklıktan çekinme hakk1 doğup bildirim yükümlülüğünden kurtulup kurtulmayacağ1 konusundaki paralel nitelikteki açıklamalar için bkz II. C. İşçinin Suçu Bildirme Yükümlülüğü 
sini sona erdirmesine sebep olacaktır. Ayrıca suçu bildirmeme suçu ve bu bağlamda bildirim yükümlülüğü, işvereni, iş sözleşmesini sona erdirirken haklı nedenle feshe başvurmaya da zorlayacaktır. İşveren suçu bildirmeme suçunu işlememek için haklı neden teşkil eden suçu (kendisinin mağduru ya da zarar göreni olmadığı suçlarda, örneğin, işçinin bir başka işçiyi yaralaması) adli mercilere bildirmelidir. $\mathrm{Bu}$ durumda da işçi-işveren arasındaki güven ciddi şekilde zarar göreceğinden ve ihbar karşısında işçi ile çalışmaya devamın beklenmesi gerçekçi olmayacağından, işverenin haklı nedenle feshe başvurması neredeyse bir zorunluluk olacaktır. Normal şartlarda haklı neden teşkil eden bir davranış karşısında işverenin, iş sözleşmesini hiçbir şey olmamış gibi devam ettirme, daha hafif sonuçları olan geçerli nedene dayanarak feshetme ya da haklı nedene başvurma seçenekleri bulunurken; işçisini ihbar etmesi zorunluluğu ile birlikte işverenin haklı nedenle feshe başvurma açısından bir seçim hakkı olacağını kabul etmek güçtür.

\section{C. İşçinin Suçu Bildirme Yükümlülüğü}

TCK m. 278 düzenlemesine göre kural olarak, işçinin de işveren gibi işyerinde işlenmekte olan ya da işyerinde olmasa da işverenin veya işyerinde çalışan diğer işçilerin gerçekleştirdiği suçlar bakımından bir suçu bildirme yükümlülüğü doğacaktır. Ancak bunun için, işçinin suçun faili veya mağduru olmaması ve TCK m. 278 istisnasına girmemesi için de faile CMK m. 45 kapsamında tanıklıktan çekinmesini mümkün kılacak yakınlıkta ${ }^{44}$ bulunmaması gereklidir.

İşçinin ceza alması için CMK m. 45' deki yakınlıkta olmaması gerektiğini söyledik; ancak CMK m. 46'daki tanıklıktan çekinmeyle ilgili ayrı bir açıklamaya yer vermemiz gerekir. Çünkü işçi avukat ya da sağlık mesleği mensubu olduğunda CMK m. 46/I-a ve I/-b uyarınca tanıklıktan çekinme gündeme gelebilir. Ama bu durumlarda doğrudan işçilerin bildirim yükümlülüğü olmayacağı söylenemez ${ }^{45}$. Özellikle sağlık mesleği mensupları için ayrı düzenleme olan TCK m. 280'den dolayı bu mümkün değildir. Kanun maddesine göre, "görevini yaptı̆̆ sırada bir suçun işlendiği yönünde bir belirti ile karşılaşmasına ră̆men, durumu yetkili makamlara bildirmeyen veya bu hususta gecikme gösteren să̆lık mesleği mensubu, bir yıla kadar hapis cezası ile cezalandırılacaktır". İşçi avukatlar için sağlık mesleği mensuplarındaki gibi özel bir düzenleme yoktur. İşçi avukat bakımından suçu bildirme yükümlülüğünü avukatın sır saklama yükümlülüğü, meslek sırrı ve

44 Bkz. III. A. 5. İşçinin Doğruluk ve Bağlılığa Uymayan Davranışları

45 Suçu bildirme yükümlülüğü bakımından bu konuda yapacağımız açıklamalar işverenin avukat ya da sağlık mesleği mensubu olması durumları için de geçerli olacaktır. 
tanıklıktan çekinme hakkı ${ }^{46}$ kapsamında incelemek gerekir ${ }^{47}$. İşçi avukat

Avukatların tanıklıktan çekinme durumlarının suçu bildirmeme suçuna etkisi ayrıca incelenmesi gereken bir çalışma konusudur. Bkz. Kitapçıoğlu Yüksel, Tülay: "Meslek ve Sürekli Uğraşıları Sebebiyle Tanıklıktan Çekinme Yükümlülüğü Altındaki Kişilerin Suçu Bildirme Yükümlülüğ̈̈”, Ceza Hukuku Dergisi, CHD, Yı1: 13, S.38, Aralık 2018, ss. 193-215.

Av.K. m. 34'te avukatların, görevlerini işlerinin kutsallığına yakışır bir şekilde özen, doğruluk ve onur içinde yerine getirmekle ve avukatlık unvanının gerektirdiği saygı ve güvene uygun biçimde davranmakla yükümlü olduğu belirtilmiştir. Ayrıca Av.K m. 36 uyarınca avukatlar, meslek sırrı saklamakla da yükümlü kılınmışlardır. Yargı kararlarında da konu edildiği üzere avukatın meslek sırrının korunması, uluslararası antlaşmalar ve Anayasamızda güvence altına alınan özel yaşamın gizliliğinin sonucu olmakla birlikte, bu koruma kamu hizmetinin içeriği ve niteliğiyle alakalıdır [Bkz. Y. 4. CD., 14.11.2011, E. 2009/19013, K. 2011/21017, www.lexpera.com, (E.T.:11.05.2020)]. Ancak doktrinde belirtildiği üzere suç, genel anlamda bir meslek sırrı niteliği taşımaz. Suçun ancak işlendikten, soruşturma veya kovuşturma konusu olduktan sonra avukatlık mesleği kapsamına gireceği kabul edilir. Bu sebeple işlenmekte olan bir suç, meslek sırrı kapsamına girmeyecektir. Ancak, suça el konulduktan sonra, avukatın doğrudan savunmasını üstlendiği müvekkilinden ya da müvekkili hakkındaki soruşturma veya kovuşturma esnasında diğer herhangi bir şekilde öğrendiği "suçun sebebiyet verdiği neticeler"'in meslek sırrı kapsamında olduğu kabul edilir (Sungurtekin Özkan, Meral: “Avukatlık Meslek Sırrının Anlam ve Önemi”, Hukuk Kurultayı 2000, Ankara Barosu, Ankara 2000, ss. 331-338, s. 332; Hafızoğulları/Acar, s. 185). Doktrinde iş avukata tevdi edilmeden önce de görevi gereği edinilmiş bilgilerin meslek sırrı kapsamına gireceği belirtilirken [Erem, Faruk: "Ceza Hukuku'nda Meslek Sırrı", Ankara Üniversitesi Hukuk Fakültesi Dergisi, Cilt: 1, Say1 1, Oca 1943, (Meslek Sirr1), ss. 35-72, s. 40; Erem, Faruk: "Avukatlık Sırrı", Ankara Barosu Dergisi, Y11: 1969, Sayı: 5, ss. 838-841, s. 838; Özbek, Veli Özer/Doğan Koray/Bacaksız, Pınar: Ceza Muhakemesi Hukuku, Gözden Geçirilmiş ve Güncellenmiş 12. Bask1, Seçkin Yayıncılık, Ankara, Ağustos 2019, (Ceza Muhakemesi), s. 617; Kolcu, s. 163; Kitapçığlu Yüksel, s. 196] bunun aksi bir görüş de bulunmaktadır. Bu görüşe göre, avukata dost olarak tevdi edilen sırlar da sır saklama yükümlülüğü kapsamında sayılmamalıdır,(Kocasakal, Ümit: Suçu Bildirmeme Suçları, Vedat Kitapçılık, İstanbul, Temmuz 2017, s. 93). Tüm bu açıklamalar doğrultusunda avukatın işlenmekte olan suçla ilgili bildirim yükümlülüğü ve bildirmezse suçu bildirmeme suçu faili olma olasılığı bulunduğu söylenebilir. Ama suça el konulduktan sonra suçun sebebiyet verdiği neticelere ilişkin bir bildirim yükümlülüğü olmadığından bu durumlarda bir suçtan söz edilemeyecektir. Çünkü savunma görevini üstlenen avukat yönünden meslek sırrı üstün değerdedir (Hafızoğulları/Acar, s. 185186). Avukatların suç ihbarı ile yükümlü kılmanın mümkün olmayacağı bunun savunma hakkına, avukatlık mesleğine zarar verebileceğini savunan görüşe göre bile istisnai durumun olabileceği belirtilmiştir [Sungurtekin Özkan, s. 336. Eski Ceza Kanunu döneminde suçu bildirme suçunun düzenlendiği 152. maddedeki her fert kavramına avukatların sokulamayacağı belirtilmesine rağmen çeşitli üstün değerlerin söz konusu olduğu durumlarda avukatlık meslek sırrının 2. sıraya düşeceği kabul edilmiştir, (Sungurtekin Özkan, s. 336-337)]. Burada işçi avukatların TCK m. 279 kapsamına girip girmeyeceği sorusu da akla gelebilir. Ancak makalemiz için önemli olan işveren ya da işçinin bir bildirim yükümlülüğü olup olmadığıdır. Yoksa hangi ceza hükmüne göre 
bakımından öncelikle somut olay incelenmeli; "bildirim yükümlülüğü doğup doğmayacağı" suçun müvekkiller, işveren veya çalışma arkadaşı avukatlar tarafından $\mathrm{m} 1$ işlendiğine ve konunun meslek sırrı kapsamına girip girmediğine göre belirlenmelidir. Ama avukatlarla ilgili yapılan değerlendirmeler 1şığında ${ }^{48}$ meslek sırrı ve tanıklıktan çekinme hakkına rağmen somut olaya göre "işçi avukat"1n da suçu bildirme yükümlülüğü doğması mümkün gözükmektedir.

İşveren açısından yaptığımız açıklamalar doğrultusunda, işçinin de bir suça dayanarak iş sözleşmesini feshetmesi suçu bildirme yükümlülüğünün yerine getirilmesi olarak kabul edilemeyecektir.

Belirttiğimiz üzere işçi, işvereni/işveren vekili ya da bir başka işçinin işlediği bir suçun mağduru, zarar göreni veya cezasızlık nedeninden yararlanacak biri değilse, suçtan haberdar olduğunda TCK m. 278 uyarınca suçu adli makamlara bildirmek zorundadır. İşçi, Türk Ceza Kanunu'ndan doğan bu yükümlülüğünü ceza alma korkusuyla yerine getirebilecektir. Böylece işçi öğrendiği suçlara rağmen, geçim kaynağını kaybetmemek adına iş sözleşmesini sona erdirmek istemese de, TCK m. 278 uyarınca yapacağ 1 ihbar iş ilişkisinin devamını olanaksız kılacaktır. Çünkü ihbar ettikten sonra işçi, iş sözleşmesini feshetmediğinde iş ilişkisinin güven içinde devam ettirilmesi hayatın olağan akışında mümkün değildir. İş ilişkisinin yürütümü bakımından doğacak aksaklıkların yanı sıra, işçi ihbar ettiği kişi karşısında fiziksel ve ruhsal açıdan tehlike altında dahi olabilecektir. Bu sebeple işçi, suçu bildirme yükümlülügü sonucu iş sözleşmesini derhal feshetmek zorunda kalacaktır.

İşçinin iş ilişkisindeki zayıf konumundan dolayı suçu bildirme yükümlülügünün işçiye etkisinin, işverene etkisine göre daha fazla olduğu ve suç bildiriminin işçi açısından daha ağır sonuçlar doğuracağı kabul edilebilir ${ }^{49}$. Çünkü işveren iş̧̧iye talimat verme yetkisine sahiptir ve işçi işvereni ihbar ettikten sonra sözleşmeyi sona erdirmezse, işveren bu yetkisini kötüye kullanarak işçiyi maddi-manevi zarara sokabilecektir. Ayrıca işçi diğer işçiler tarafından mobbinge de maruz kalabilir. İşçi işvereni ihbar ettikten sonra her

cezalandırılacağı ceza hukukunun konusudur. Zaten avukatların ceza hukuku bağlamında kamu görevlisi olarak kabul edilip edilmeyeceği tartışmalı olduğundan net bir cevap da verilemez. Ayrıntılı bilgi için bkz. Özbek, Veli Özer/Meraklı, Serkan: "Ceza Hukukunda Avukatın Kamu Görevlisi Olarak Kabul Edilebilirliği Sorunu”, Dr. Dr. h. c Silvia TELLENBACH'a ARMAĞAN, Seçkin Yayıncılık, Ankara, Mayıs 2018, ss. 1157-1176.

48 Bkz. II. C. İşçinin Suçu Bildirme Yükümlülüğü dpn. 47.

49 Buna ilişkin olarak ayrıca bkz. III. B. İşçinin Haklı Nedenle İş Sözleşmesini Feshedebilmesi Bakımından 
şeyi göze alıp iş sözleşmesini devam ettirmesine rağmen, bir süre sonra maruz kaldığı tutum ve davranışlara dayanamayıp somut olaya göre süreli veya haklı nedenle feshe de başvurabilir. Ya da İşK. m. 18/III-c'ye ${ }^{50}$ rağmen işveren, gerçek gerekçe işçinin ihbarı olan ama görünürde başka nedenler bulunan somut olaya göre geçerli ya da haklı nedenle feshe başvurabilir (Bunların yerindeliği somut olaya ve gösterilen nedene göre değişecektir, ama temelinde yatan "ihbar edilmiş olması nedeni" nin hukuka uygun olmadığ kesindir). İşçi hiçbir sıkıntı yaşamadan ihbarda bulunur bulunmaz baştan iş sözleşmesini sona erdirdiğinde de, iş sözleşmesinin sona ermesinin işçileri daha fazla etkileyeceği gerçeğgi ${ }^{51}$ karşısında suçu bildirme yükümlülüğünün işçi açısından daha ağır sonuçları olacağı açıktır.

İster ihbar sonrası ilerleyen süreçte ister başlangıçta gerçekleşsin iş sözleşmesi sona erdiğinde işçi geçim kaynağını kaybetmiş olmasının yanı sıra, yeni iş ararken ihbarcı olarak fişlenme sebebiyle iş bulamama gibi başka zorluklarla da yüz yüze kalabilecektir.

İşK. m. 24/II'deki haklı nedenlere baktığımızda, bu nedenlerde açıkça yer alan ya da karş1lık gelebilecek suçlarda işçi, suçun mağduru ya da suçtan zarar göreni olacak ve suçu bildirme yükümlülüğ̈ doğmayacaktır. Ama bu işçinin suçu bildirme yükümlülüğü olmadığı anlamına gelmez. İşçinin, işyerinde ya da işyeri dışında, işveren/işveren vekili ya da işyerindeki diğer işçilerin gerçekleştirdiği, kendisine karşı olmayan (suçun mağduru ya da zarar göreni olmadığı) suçlar bakımından bildirim yükümlülüğü mevcuttur; sadece bu durumlar İşK. m. 24/II'de açıkça ifade edilmemiştir.

Hem iş̧i hem de işveren açısından "ahlak ve iyi niyet kurallarına uymayan haller ve benzerleri" başlıklı haklı nedenlerin "ve benzerleri" ifadesi sebebiyle sınırlı sayım olmadığı kabul edilmektedir ${ }^{52}$. Bu örnekseyici sayım sebebiyle "işçinin işverenin, işveren vekilinin ya da diğer işçilerin işyeri dışında ya da içinde kendisine ve ailesine karşı olmayan suçların işlenmesi" durumunda haklı nedenle feshin mümkün olduğu düşünülebilirse de; yargı kararlarında bu durumun İşK. m. 24/II'deki "ve benzerleri” ifadesi kapsamına sokulacağı kesin olarak söylenemeyecektir. Çünkü burada sayılan nedenler hep işçiye ya da yakınlarına karşı gerçekleştirilen hal ve hareket-

50 Ayrıca bkz. III. B. İşçinin Haklı Nedenle İş Sözleşmesini Feshedebilmesi Bakımından

51 Gerek, Nüvit: "İşveren Tarafından Gerçekleştirilen Haksız Fesih-Usulsüz Fesih-Kötü Niyetli Fesih", Kara Tahta İş Yazıları Dergisi, Yı1: 2015, S.2, ss. 1- 17, s. 3.

52 Bkz. III. A. İşverenin Haklı Nedenle İş Sözleşmesini Feshedebilmesi Bakımından. III. kısımdaki alt başlıklarda görüleceği üzere bu anlayışla maddede açıkça yer almayan durumlar haklı neden kapsamında sayılmıştır. Ör: Yargı kararlarında mobbing (psikolojik taciz) haklı neden kabul edilmiştir. 
lerdir. Dolayısıyla "işyerindeki işveren/işveren vekili ve diğer işçilerin işçiye ve ailesine karşı olmayan, işyerinde ama asıl işyeri dışında işlenmiş suçları" işçinin dayanabileceği haklı nedenler kapsamına sokmanın geniş bir yorum olacağı ileri sürülebilir. Bu sebeple, suçu bildirme yükümlülüğü sebebiyle işverenden daha zor duruma düşecek işçi için en azından "işverenin başkalarına karşı işyeri ve işyeri dışında işlediği suçların" da haklı neden sayılabileceğine ilişkin açık bir düzenleme getirilmesi faydalı olabilecektir.

Suçu bildirme yükümlülüğü uyarınca işçinin suç bildiriminin, sadakat borcuna aykırılık teşkil edip etmeyeceğini de irdelememiz gerekir. İş sözleşmesinin kişisel niteliğinden dolayı, "taraflar arasında oluşması ve sürmesi gereken güven" için gerekli işçiyi gözetme yükümlülügüne karşılık olarak işçinin de "sadakat borcu" vardır. İşçinin bu borcu, "özen ve sadakat borcu" başlıklı Türk Borçlar Kanunu'nun 396. maddesinde açıkça düzenlenmiştir.

TBK m. 396'dan yola çıkarak sadakat borcunun öncelikle iki temel yükümlülüğü barındırdığı söylenebilecektir. Bunlar "sır saklama" ve "rekabet etmeme"dir. TBK m. 396/III'de yer verilmiş olan rekabet etmeme borcu" işverenin sadakat borcu kapsamında, bir yapmama borcu niteliği taşır ${ }^{54}$. Bu borç uyarınca işçi, iş sözleşmesi süresince işvereni ile rekabet oluşturacak bir işi kendi adına yapmaması; işverene rakip bir başka işverenin yanında çalışmaması; işverene rakip bir kuruluşta ortak olmaması veya başka bir sıfatla dahi böyle bir kuruluşla ilgisi bulunmaması gibi yükümlülüklere uygun hareket etmek zorundadır ${ }^{55}$.

Sır saklama yükümlülüğü ${ }^{56}$ ise TBK m. 396'nın dördüncü fikrasında düzenlenmiştir. Düzenleme uyarınca işçi, iş ilişkisisi süresince (hatta işverenin haklı menfaati için gerekli olduğu ölçüde iş ilişkisi sonrasında da) işe veya işletmeye ilişkin olup saklanması zorunlu bilgileri üçüncü kişilere açıklamamalıdır ${ }^{57}$. Sır saklama yükümlülüğü kapsamı, maddede "iş gördüğü sırada

Aslında, rekabet etmeme borcu, iş sözleşmesi devamında ve sonrasında olmak üzere iki farklı şekilde karşımıza çıkar. İş ilişkisi devamındaki rekabet borcu TBK m. 396/III'de yer almaktayken; iş sözleşmesinin sona ermesinden sonra tarafların rekabet yasağ 1 kararlaştırmasıyla gündeme gelecek borç TBK m. 444'de düzenlenmiştir.

54 Mollamahmutoğlu/Astarlı/Baysal, s. 150.

55 Mollamahmutoğlu/Astarlı/Baysal, s. 150; Narmanlıŏglu, s. 274.

56 Sadakat ve bünyesinde barındırdığı sır saklama borcu ile ilgili ayrıntılı bilgi için bkz. Arslan Ertürk, Arzu: Türk İş Hukuku'nda Sadakat Borcu, Doktora Tezi, İstanbul 2007, s. 269 vd.; Alpagut, Gülsevil: "İşçinin Sadakat Borcu ve Türk Borçlar Kanunu ile Getirilen Düzenlemeler”, Sicil İHD, Y11: 2012, S.25, ss. 23-32; Albayrak Gül, Hande: "İş̧̧inin Sadakat Borcu", Bahçeşehir Üniversitesi Hukuk Fakültesi Dergisi, Yıl: 2016, C.11, Sayı: 141-142, ss. 121-197, Arı, Mehmet, "İşçinin Sır Saklama Yükümlülüğü", Terazi Hukuk Dergisi, C.11, S.115, 2016, ss. 58-63. 
öğrendiği, özellikle üretim ve iş sırları gibi bilgiler ${ }^{58 "}$ olarak açıcça belirlenmiştir. Doktrinde ayrıca, işverence gizli kalması gerektiği bildirilen veya böyle bir açıklama yapılmamakla birlikte işverenin bu yöndeki iradesinin bilindiği veya bilinebildiği hallerde; işverenin mali, kişisel ve ailevi ilişkilerinin de bu kapsamda değerlendirileceği belirtilmiştir ${ }^{59}$. Bu açıklamalarımıza göre, sır saklama yükümlülüğü kapsamına işverenin suçlarının gireceğini söylemek mümkün değildir. Yukarıda yer verdiğimiz üzere, her ne kadar doktrinde kişisel bazı sırların da saklama yükümlülüğü kapsamına girebileceği belirtilmişse de, bununla işçinin işlediği suçların kastedildiğini düşünmüyoruz.

İşçinin suçu bildirme yükümlülüğünün, işçinin sadakat borcu ve bu kapsamda sır saklama yükümlülüğüne aykırılık olup olmayacağı değerlendirilmesinde, sadakat borcu sınırları da önem arz edecektir.

İş ilişkisinin gereği olmasının yanı sıra Türk Borçlar Kanunu'nda açıkça belirtildiğinden işçinin işverene sadık olması ve sır saklaması zorunludur; ancak bu durum suçu bildirme yükümlülüğ̈nü kaldıracak hukuka uygunluk nedeni olarak değerlendirilemeyecektir. Çünkü her hak ve yükümlülük gibi işçinin bu borcu da sinırsız değildir.

Öncelikle TBK m. 396'nın lafzını incelediğimizde, işverenin haklı menfaatinin korunmasında sadakatle davranmak ve yine haklı menfaatinin korunması için gerekli olduğu ölçüde sır saklamakla yükümlü olunduğunu görürüz. Anlaşıldığı üzere işverenin haklı ve meşru menfaati, sadakat borcunun bir sınırını teşkil etmektedir. Haklı bir menfaat yoksa sadakat borcu da olmayacaktır ${ }^{60}$. Haklı menfaat değerlendirilmesinin ise TMK m. 2 temelinde somut olayın koşulları ve çalışma hayatının gerekleri göz önünde tutularak yapılacağı belirtilmiştir ${ }^{61}$. İşçinin, işverenin işlediği bir suçu ihbar etmemesinde doğal olarak işverenin menfaati vardır; ama bunun haklı bir menfaat olduğu söylenemeyecektir. Dolayısıyla işçinin ihbarı sadakat borcuna aykırılık olarak nitelendirilemez.

"İşverenin işlemediği ama işyerinde işlenen ya da bir başka işçisinin işyeri dişında işlemiş olduğu bir suçun ihbar yükümlülüğünde" ise, işverenin

58 Üretim sırları kapsamına, "üretim süreci, üretim talimatları, yeni üretim yöntemleri ve ürünler, sayısal çizelgeler, modeller veya araştırma sonuçları" gibi bilgiler girerken; iş sırları ile "üretim dışında kalan pazarlama, organizasyon, tedarik, müşteri listeleri, fiyat hesaplamaları, reklam stratejileri, gelir kaynakları, personel yapısı ve stok yapısı" ifade edilmiştir (Mollamahmutoğlu/Astarlı/Baysal, s. 148; Alpagut, s. 28)

59 Mollamahmutoğlu/Astarlı/Baysal, s. 148.

60 Centel, s.41; Tunçomağ/Centel, s.100; Arslan Ertürk, s.138-139; Alp, Whistleblowing, s.121; Albayrak Gül, s. 138.

61 Alpagut, s. 31. 
işyerinin itibarının zedelenmesini istememesi ve işyeri düzeninin bozulmaması bakımından haklı bir menfaati vardır. Ancak işyerinde işlenen suçlar bakımından TBK m. 417'deki önleme yükümlülüğü düşünüldügünde yine işçinin suçu bildirmesi, "sadakate aykırılık" ve "sözleşme ihlali" olarak değerlendirilemez. İşverenin işlemediği ve işyeri dişında gerçekleşen suçlarda da sadakat borcu ihlali olmayacaktır. Burada da dayanağımız, sadakat borcunun sınırlarından olan "Anayasal temel hak ve özgürlükler" ile "işçinin temel hak ve özgürlüklerinden işverenin menfaati için feragat etmesinin beklenememesi" dir $^{62}$. İşçinin haklı menfaati ile işverenin haklı menfaati karşı karşıya geldiğinde hangisinin üstün geleceği somut olaya göre değerlendirilmeli ve ölçülülük ilkesi doğrultusunda karar verilmelidir ${ }^{63}$. Burada işçi suçu ihbar etmezse, suçu bildirmeme suçundan mahkûm edilebilecektir; bu durumda da işçiden işverenin menfaatini düşünmesi beklenemez. İşçinin menfaati dişında, işçinin suçu bildirme yükümlülügünün taşıdığı amaca da bakmak gerekir. İşçinin suçu bildirmesiyle diğer bir ifadeyle suçu bildirmeme suçuyla, suçun ya da suçun sonuçlarının önlenmesi istenmektedir. Burada işçinin bireysel menfaatinin ötesinde kamu yararı da vardır. İşverenin haklı menfaati ile TCK m. 278'in koruduğu hukuki yarar karşılaştıııldığında işçinin bildirim yükümlülüğü öne çıkacaktır. İşverenin haklı menfaatinden bile daha üstün anayasal "kişisel verilerin korunması hakkı (AY m. 20)" ve buna mukabil diğer kanun düzenlemelerine ${ }^{64}$ rağmen yukarıda da yer verdiğimiz üzere TCK m. 280 uyarınca, sağlık mesleği mensupları, karşısına gelen olaylarda suça dair bir belirti görürse bunu bildirmek zorundadır. TCK m. 280, AY m. 13 doğrultusunda temel hak ve özgürlüklerin Kanun ile s1nırlandırılmasına örnek gösterilebilir. Dolayısıyla TCK m. 280 ile Anayasal temel hak ve özgürlüklerin ihlal edilmediği kabul edilebiliyorsa, TCK m. 278 uyarınca işçinin hareket etmesinin sadakat borcunu ihlali olarak kabulü hakkaniyete uygun düşmeyecektir. Zira maddede söz konusu olan suç ya da suçun sonuçlarının önlenmesidir ve bu durum karşısında diğer hak ve menfaatler ikinci plana itilebilmektedir. Buna bir başka örnek ise TCK m. 24/III tür. Bu düzenlemeye göre konusu suç teşkil eden emir hiçbir surette yerine getirilemez. Aksi takdirde yerine getiren ile emri veren sorumlu olur.

62 Alp, Whistleblowing, s. 123; Albayrak Gül, s. 138. Sadakat borcunun özel hukuktaki kişilik hakkından ve Anayasal temel haklardan kaynaklanan sınırları için bkz. Arslan Ertürk, s. 213-239.

63 Ertürk, s. 115,116; Alp, Whistleblowing, s. 123; Albayrak Gül, s. 138-139.

64 Bkz. Tıbbi Deontoloji Tüzüğü m. 4, Hasta Hakları Yönetmeliği m. 20 - m. 21 - m. 23, Hekimlik Meslek Etik Kuralları m. 9. 
Sonuç olarak faili ya da mağduru olmadığı ya da CMK m. 45 anlaminda tanıklıktan çekinmesi söz konusu olmayan işçinin suçu bildirme gerekliliği sebebiyle yaptığı ihbar, işverence sadakatsizlik olarak değerlendirilip işçinin iş sözleşmesinin haklı ya da geçerli nedenle feshedilmesine yol açamaz. Zaten İşK. m. 18/III-c uyarınca "mevzuattan veya sözleşmeden doğan haklarını takip veya yükümlülüklerini yerine getirmek için işveren aleyhine idari veya adli makamlara başvurma veya bu hususta başlatılmış sürece katılma” geçerli neden sayılamayacağından işveren geçerli nedenle feshe ve evleviyetle haklı nedenle derhal feshe başvuramayacaktır. Ama bu, suçu bildirme yükümlülüğünün yukarıda açıkladığımız işçi açısından doğacak olumsuz sonuçlarının önüne geçemeyecektir.

\section{HAKLI NEDEN OLARAK SUÇ}

\section{A. İşverenin Haklı Nedenle İş Sözleşmesini Feshedebilmesi Bakımından}

İş Kanunu m. 25'de işverenin iş sözleşmesini haklı nedenle, bildirim sürelerine gerek olmaksızın derhal feshedebileceği durumlar sayılmıştır. İşverenin haklı nedenle iş sözleşmesini feshi, kanunda düzenlendiği üzere, "sağllk sebepleri", "ahlak ve iyi niyet kurallarına uymayan haller ve benzerleri", "zorlayıcı sebepler" ve "koruma tedbirleri sebebiyle devamsizllk" şeklinde 4 gruba ayrılarak incelenebilir. İşçinin işlemiş olduğu suçlardan dolayı haklı nedene başvurulması "ahlak ve iyiniyet kurallarına uymayan haller ve benzerleri" kapsamında düzenlenmiştir.

Bir haklı nedenin hangi kapsamda olduğunun tespiti önemlidir. Çünkü "ahlak ve iyiniyet kurallarına uymayan haller ve benzerleri" kapsamında işçinin iş sözleşmesinin işveren tarafindan feshi durumunda işçi, onun için çok önemli olan kıdem tazminatından mahrum kalacaktır ${ }^{65}$.

İşK. m. 25/II'de "ahlak ve iyi niyet kurallarına uymayan haller ve benzerleri” kapsamında çeşitli suçlara açıkça yer verilmiştir. Ama bu başlıktaki bazı nedenlerin suç niteliği taşıdığı ifade edilmemişse de, yapılacak değerlendirmelerle bunların da ceza hukuku anlamında bir suça karşıllk gelebileceği sonucuna ulaşılabilir.

İşçi bakımından doğuracağı sonuçları sebebiyle İşK. m. 25/II'de sayılan işverenin haklı nedenlerinin neler olduğunun belirlenmesi çok önemlidir. Kanun koyucu bu bentteki nedenleri düzenlerken sınırlı sayım değil "ve

65 Kıdem tazminatı ve şartları ile ilgili ayrıntılı bilgi için bkz. Çelik/Caniklioğlu/ Canbolat, s. 628 vd.; Eyrenci/Taşkent/Ulucan, s. 261 vd.; Süzek, s. 726 vd., Mollamahmutoğlu/Astarlı/Baysal, s. 307 vd.; Narmanlıoğlu, s. 535 vd. 
benzeri haller" ifadesine yer vererek örnekseyici sayım yapmayı tercih etmiştir $^{66}$. Yargitay da bu doğrultuda karar vermiştir ${ }^{67}$. Doktrinde bu örnekseyici sayımın, taraflardan sözleşmeyi devam ettirmesi beklenemeyecek farklı durumlara karşı işverenleri koruyacağı belirtilmiştir ${ }^{68}$. Kazuistik kanun yapımı modern yaşantıya, gelişen ve değişen hayat şartlarına uygun düşmeyeceğinden $\mathrm{m}$. 25/II'de yapılan örnekseyici sayımın yerinde olduğunu kabul etsek de; iş sözleşmesinin m. 25/II kapsamında derhal sona ermesi, işçi için işsizlik ödeneğinden yararlanma mahrumiyeti ve kıdem tazminatı kaybı gibi önemli sonuçlara sebep olacağından "örnekseyici sayım"ın kötü durumlara yol açabileceği kanaatindeyiz ${ }^{69}$. İşçi aleyhine olan bu durumun önüne geçebilmek için, doktrinde İşK. m. 25'deki "ve benzerleri” genişletici ifadesinin ölçülülük ve işçi lehine yorum ilkeleri karşısında dar yorumlanmasının yerinde olacağı belirtilmiştir ${ }^{70}$.

Ayrıca doktrinde İşK. m. 24 ve m. $25^{\prime}$ de sayılan nedenler dışında bir durumla karşılaşıldığında, Borçlar Kanunu'nda hizmet sözleşmesinin haklı nedenle feshini düzenleyen TBK $\mathrm{m}$. 435'e başvurulabileceği de ileri sürmüştür. Bu görüşe göre, İşK. m. 24/II ve İşK. m. 25/II'de sınırlı sayım ilkesi geçerli olmadığından, düzenlemelerde açıkça neden olarak sayılmayan bir durumla karşılaşıldığında, bunun haklı neden sayılıp sayılmayacağının tespiti için TBK m. 435/II "Sözleşmeyi fesheden taraftan, dürüstlük kurallarına göre hizmet ilişkisini sürdürmesi beklenemeyen bütün durum ve koşullar, haklı sebep sayllır" hükmünün esas alınmas1 yerinde olacaktır ${ }^{71}$. Ama bu görüşün aksine, İşK. m. 24 ve İşK. m. 25 düzenlemeleri karşısında İş

66 Baysal, Ulaş: İşçinin Yetersizliğinden Kaynaklanan Geçerli Sebeple İş Sözleşmesinin Feshi, Adalet Yayınevi, Ankara, Kasım 2011, s. 7; Bedük, Mehmet Nusret: "İş Sözleşmesinin İşçi Tarafından Feshi ve Feshin Hukuki Sonuçları”, Selçuk Üniversitesi Hukuk Fakültesi Dergisi, Yı1:2019, C.27, S.3, ss. 679-726, s. 693; Yamakoğlu, s. 47. Bkz. 22. HD., 12.05.2014, 2014/11569 E., 2014/12397 K., [(Çalışma ve Toplum Dergisi, 2015/3, S.46, (www.calismatoplum.org, E.T.:17.09.2020)].

68 Baysal, s. 7.

69 Aynı açıklamalar İşK. m. 24/II için de geçerlidir. Ancak işçinin işveren karşısındaki konumu sebebiyle işverenin dayanacağ haklı nedenlerin örnekseyici sayılmasının sonuçları işçinin başvuracağı nedenlerin örnekseyici sayılmasına oranla çok daha ağır olduğundan "işçiyi koruma ilkesi de düşünüldüğünde" bu örnekseyici sayım eleştirisi İşK. m. 25/II bendi bakımından daha fazla önem arz etmektedir.

Alp, Mustafa: "İș İlişkisinin Sona Ermesi ve Kıdem Tazminatı”, Yargıtay’ın İş Hukuku ve Sosyal Güvenlik Hukuku Kararlarının Değerlendirilmesi 2013, 2. Baskı, Onikilevha Yayıncılık, İstanbul, Kasım 2017, ss. 175-257, (Değerlendirme), s. 194.

71 Yürekli, Sabahattin: Türk Borçlar Kanununa Göre Hizmet Sözleşmesinin Sona Ermesi, Güncellenmiş 3. Bask1, Seçkin Yayıncılık, Ankara, Temmuz 2016, s. 272. 
Kanunu uygulamasında TBK m. 435'e başvurulamayacağı da kabul edilmiştir $^{72}$

"Ahlak ve iyi niyet kurallarına uymayan haller ve benzerleri” başlığı altındaki nedenlerin çoğunluğu ceza hukuku anlamında suç teşkil edebilecek davranışlardır. Aşağıda bu nedenler tek tek ele alınacaktır.

\section{1. İşçinin İşvereni Yanıltması}

İş sözleşmesinin kurulması aşamasında taraflar arasında mevcut bir sözleşme ilişkisi yoktur. Ama işveren ve işçi adayı, dayanağını Türk Medeni Kanunu 2. maddesinde bulan borçlar hukukundaki "koruma yükümlülükleri" uyarınca, görüşmelerin başladığ 1 ilk andan itibaren karşılıklı hak ve menfaatlerini korumak ve birbirlerine zarar vermemek için özen göstermekle yükümlüdürler ${ }^{73}$. Bu doğrultuda, işveren "işçi adayına soru sormak" başta olmak üzere çeşitli şekillerde işçiyle ilgili bilgi edinme hakkına sahipken, işçinin de bu soruları doğru bir şekilde cevaplaması ve işvereni yanıltmaması gerekir $^{74}$. Aksi halde, kurulmuş olan bir iş sözleşmesinin işveren tarafından sona erdirilmesi mümkün olabilir. İşK. m. 25/II-a'ya göre iş sözleşmesi yapıldığı sırada işçi, sözleşmenin esaslı noktalarından biri için gerekli nitelikler kendisinde bulunmadığı halde bulunduğunu söylerse veya gerçek olmayan bilgiler vererek işvereni yanıltırsa, işveren ahlak ve iyi niyet kurallarına uymayan haller kapsamında iş sözleşmesini derhal feshedebilecektir ${ }^{75}$.

İşçi, soruları yanlış cevaplama veya kendiliğinde yalan beyanlarda bulunmanın yanı sıra, susarak ya da işverende uyanan yanlış kanaati devam ettirerek de işvereni yanıltabilecektir. Bir inşaat işçisinin epilepsi hastası olduğunu işverenine söylememesi, susarak işvereni yanıltmaya örnektir ${ }^{76}$. Sonuç olarak işle ilgili bilgi vermekle yükümlü olduğu konularda, işveren soru sormasa da, işçi bir açıklama yapmayarak aksi bir kanaat oluşmasına

Çelik/Caniklioğlu/Canbolat, s. 576. Aynı açıklamalar, işçinin haklı nedenle iş sözleşmesini feshedebilmesi bakımından İşK. m. 24'deki "ahlak ve iyi niyet kurallarına uymayan haller ve benzerleri” başlığı için de geçerlidir.

73 Süzek, s. 311; Erkanlı Başbüyük, s. 13.

74 İşçi ve işverenin iş sözleşmesi kurulması aşamasında hak ve yükümlülükleri için bkz. Erkanlı Başbüyük, Betül, Tarafların İşs sözleşmesinin Yapılması Sırasındaki Hak ve Yükümlülükleri, Adalet Yayınevi, Ankara, Mart 2015.

75 Bu haklı nedenle ilgili ayrıntılı bilgi için bkz. Odaman, Ahlak ve İyiniyet Kuralları ve Benzerleri, s. 85 vd.; Odaman, Serkan: "İş̧̧inin İşe Başvuru Esnasında İşvereni Yanıltması ve Hukuki Sonuçları", Tekstil İşveren Dergisi, Ekim-2002, S. 274, (İşçinin İşvereni Yanıltması), ss. 40-43; Savaş, s. 67-72; Arslan Durmuş, s. 47-57.

76 Süzek, s. 668; Mollamahmutoğlu/Astarlı/Baysal, s. 238; Senyen Kaplan, İş Hukuku, s. 282-283; Odaman, Ahlak ve İyiniyet Kuralları ve Benzerleri, s. 87; Odaman, İşçinin İşvereni Yanıltması, s. 40; Savaş, s. 68; Arslan Durmuş, s. 49. 
yol açtıysa "yükümlülük ihlali" ve "işvereni yanıltma" gündeme gelecektir. Yargıtay da, "güvenlik görevlisi bir işçinin, işe alım sırasında doldurduğu formda sabıkasını gizlemesi"ni yalan beyan olarak değerlendirmiş ve bu durumu işveren lehine haklı fesih nedeni kabul etmiştir ${ }^{77}$. Kanaatimizce burada işçi güvenlik görevlisi olduğu için karar yerindedir; ancak genel anlamda haklı neden teşkil etme açısından sabıkanın içeriğinin ne olduğu da önemlidir. İşçilerin sabıklarını açıklamaması veya adli sicil kayıtlarını sunmamalarının haklı eden teşkil edip etmeyeceğini, başvurulan iş ve sabıkanın niteliğinin esas alındığı bir değerlendirme sonrası söylemek gerekir. Çünkü işçinin işi ile ilgisi olmayan bir sabıkası konusunda açıklama yapma yükümlülüğü olduğunu kabul etmek, işçinin kişilik haklarına aykırılık teşkil edecektir. Doktrinde de işçi adayının işle maddi bağlantısı olan eski mahkûmiyetlerini bildirmesi gerektiği belirtilir. Dahası, iş ile maddi bağlantısı olan mahkûmiyetler bile adli sicilden silindiyse işçinin kendisine bu konuda soru yöneltilse dahi sabıkası olmadığını söyleyebileceği de ileri sürülmüştür $^{78}$.

Sonuç olarak işçinin bir davranışının "işvereni yanıltma" olarak kabul edilebilmesi için, öncelikle söz konusu durumun sözleşmesinin esaslı noktalarına ilişkin olup olmadı̆̆ına bakılmalıdır ${ }^{79}$.

İşçinin açığa vurmama hakkı olduğu konularda, "işçinin işvereni yanıltması haklı nedeni” kural olarak oluşmayacaktır. Örneğin, işçinin işe alımda işverene hangi sendikaya üye olduğunu söylememesi, hatta üyeliğine ilişkin olarak yalan söylemesi, sendika özgürlügünün anayasal güvencesi AY m. 51, İşK. m. 5'deki eşit davranma ilkesi ve Sendikalar ve Toplu İş Sözleşmesi Kanunu ${ }^{80}$ m. 25/I karşısında işvereni yanıltma olarak sayılmamak$\operatorname{tadır}^{81}$. Kadın işçinin hamile olup olmadığını sormak ise anayasal özel

Bkz. Y. 9. HD. , 22.01.1998, E. 1998/19393, K. 1998/432; Y. 9. HD. , 6.6.2000, E. 2000/4727, K. 2000/7993, www.kazanci.com, (E.T.:11.06.2020),

78 Eyrenci, Öner: "İşe Girişte Personel Seçimi İle İlgili Hukuki Sorunlar", İş Hukuku ve Sosyal Güvenlik Hukuku Türk Milli Komitesi 15. Yıl Armağanı, Bayrak Matbaacılık, 1991, ss. 239-262, s. 255-256; Senyen Kaplan, Bilgisayar Bakımından İşçinin Kişilik Hakları, s. 380, Ertürk, s. 71-72; Odaman, Ahlak ve İyiniyet Kuralları ve Benzerleri, s. 91-92; Odaman, İşçinin İşvereni Yanıltması, s. 42; Arslan Durmuş, s. 54; Erkanlı Başbüyük, s. 80.

79 Odaman, Ahlak ve İyiniyet Kuralları ve Benzerleri s. 87; Ünlü, Vahap: "İş Başvurusu Sırasında İşçinin İşvereni Yanıltması”, Sicil İHD, Y11: 4, S.14, Haziran 2009, ss. 276283, s. 280; Savaş, s. 67.

80 R.G. Tarih: 07.11.2012 R.G. Sayı: 28460

81 Çelik/Caniklioğlu/Canbolat, $\quad$ s. 588; Eyrenci, $\quad$ s. 256; Süzek, s. 668 , Mollamahmutoğlu/Astarlı /Baysal, s. 238; Ertürk, s. 74; Odaman, Ahlak ve İyiniyet Kuralları ve Benzerleri, s. 93; Öktem Songu, Sezgi: “Anayasal Bir Temel Hak Olarak 
hayatın gizliliği hakkına (AY m. 20) ve Türkiye'nin onaylamış olduğu Birleşmiş Milletler Kadınlara Karşı Her Türlü Ayrımcılığın Önlenmesi Sözleşmesi ${ }^{82} \mathrm{~m} .11$ e aykırı olacaktır ${ }^{83}$. Ayrıca bu soru iş sözleşmesi yapılırken cinsiyet ve hamilelik gibi sebeplerle farklı işlemde bulunulmasını engelleyen İşK. m. 5'deki eşit davranma ilkesine de uygun görülemez ${ }^{84}$. Bu sebeple kadın işçinin (ya da eşinin bebek bekleyip beklemediğine yönelik olarak erkek işçinin) bu tür sorulara da cevap vermeyebileceği ve yanlış bilgi verirse de bunun feshe neden olamayacağı kabul edilir ${ }^{85}$.

Ancak işçiye sorulabilecek sorular, işçinin açığa vurmama hakkı ve işçinin açıklama yapma yükümlülüğünün kapsamı bakımından bazı istisnai durumlar da vardır. Örneğin, kimyasal atıklarla uğraşma ya da x ışınlarına maruz kalma gibi iş sağlığı ve güvenliği bakımından sorun çıkaracak alanlarda kadın işçilere hamile olup olmadığ sorulabilecektir. Bu sorulara verilen yanlış cevaplar da işvereni yanıltma olarak kabul edilip haklı nedenle feshe imkân sağlayabilecektir. Dahası işveren soru sormasa bile bu gibi durumlarda işçinin kendiliğinden açıklama yapma zorunluluğu bulunmaktadır. $\mathrm{Bu}$ durum sporculuk, mankenlik ve sahne sanatları gibi alanlarda iş görme ediminin niteliğinden dolayı da geçerli olacaktır ${ }^{86}$.

İstisnalardan bir diğeri de sendikaya alınacak sekretere hangi sendikaya üye olduğunun sorulabilecek olmasıdır. Söz konusu istisna bakımından manevi amaçlı işletmelere değinmek gerekir. "Manevi amaçlı işletme (Tendenzbetrieb)" kavramı Alman İşyeri Düzeni Kanunu'nun (BetrVG) ${ }^{87}$ 118. maddesinde düzenlenmiştir. Hükme göre, doğrudan doğruya ve ağırlıklı olarak belli bir dini, politik, sınıfsal, eğitsel, sanatsal amaçlara veya basın

İfade Özgürlüğünün İşçi Açısından İşyerindeki Yansımaları”, Polat SOYER'e Armağan, DEÜHFD, Y11: 2013, C.15, Özel Say1, 2014, (İfade Özgürlüğ̈̈), ss. 609-650, s. 634; Erkanlı Başbüyük, s. 71, 72-73.

823 Eylül 1981 tarihinde yürürlüğe giren bu sözleşme 11.06 .1985 tarih ve 3232 say1l Kanunla uygun bulunmuş, 24.07.1985 tarihinde 85/9722 sayılı kararla Bakanlar Kurulu'nca onaylanmış ve 14 Ekim 1985 tarih ve 18898 sayılı Resmi Gazete'de yayımlanmıştır.

83 Çelik/Caniklioğlu/Canbolat, s. 588; Eyrenci, s. 254-255; Senyen Kaplan, Bilgisayar Bakımından İşçinin Kişilik Hakları, s. 379; Senyen Kaplan, İş Hukuku, s. 283; Erkanlı Başbüyük, s. 77.

84 Eyrenci/Taşkent/Ulucan, s. 250; Erkanlı Başbüyük, s. 77.

85 Eyrenci, s. 255; Eyrenci/Taşkent/Ulucan, s. 250. Kadının hamileliğine ilişkin sorularla ilgili ayrıntılı bilgi için bkz. Ertürk, s. 68-71; Arslan Durmuş, s. 52-53; Erkanlı Başbüyük, s. 76-79.

86 Eyrenci, s. 255; Eyrenci/Taşkent/Ulucan, s. 250; Ertürk, s. 76-77; Arslan Durmuş, s. 53; Erkanlı Başbüyük, s. 77.

87 BetrVG-Betriebsverfassungsgesetz. 
yayın ve film özgürlüğü kapsamında düşünce açıklaması ve raporlama amacına ulaşmaya hizmet eden işletmeler, manevi amaçlı işletmelerdir. Manevi amaçlı işletme kavramı, Türk mevzuatında yer alan bir ifade değildir. Ancak bu duruma örnek teşkil edecek 6701 sayılı Türkiye İnsan Hakları Ve Eşitlik Kurumu Kanunu ${ }^{88}$ 7. maddesi bulunmaktadır. Maddenin I-d bendince bir dine ait kurumda, din hizmeti veya o dine ilişkin eğitim ve ögretim vermek üzere sadece o dine mensup kişilerin istihdamı mümkün görülebileceğinden, bu kişilere dini inanca yönelik sorular sorulabilecektir ${ }^{89}$. Yukarıda verdiğimiz sendikaya alınacak sekreter örneğinin de aslında manevi amaçlı işletmelerin bu istisnai durumunun sonucu olduğu söylenebilir.

İşK. 25/II kapsamındaki bazı hükümlerde açıkça suç kavramına yer verilmemişse de, bunların yapacağımız değerlendirmelerle TCK'daki bazı suçlara karşıllk gelebileceğini tespit edebileceğimizi belirtmiştik. Zaten işçinin işvereni yanıltmasını çalışmamız kapsamında ele almamızın sebebi bu düşünceye dayanmaktadır.

İşçinin işvereni yanıltması haklı nedeninin Türk Ceza Kanunu anlamında "dolandırıcılık suçu" teşkil edip etmeyeceğine ilişkin bir değerlendirme yapılabilir. Dolandırıcılık TCK m. 157'de düzenlenmiştir. Maddeye göre "hileli davranışlarla bir kimseyi aldatıp, onun veya başkasının zararına olarak, kendisine veya başkasına bir yarar sağlanması" dolandırıcılık suçunu oluşturur. İşK. m. 25/II-a alt bendinde tasvir edilen haklı nedenin somut olaya göre dolandırıcılık suçu olarak nitelendirilebileceği kanısındayı $^{90}$. Özellikle, işçi sahte cv, sertifika, ehliyet, diploma vs. düzenlemişse bunlar açıkça hileli davranışlara karşılık geleceğinden bu suçun gerçekleşmiş olduğunu söyleyebilmek daha kolay olacaktır. Kanaatimizce burada sadece dolandırıcılık suçu değil TCK m. 207 de yer alan özel belgede sahtecilik suçu $^{91}$ da gündeme gelebilecektir.

\section{2. İşçinin Şeref ve Namusuna Dokunacak Söz ve Davranışları}

İşK. m. 25/II-b alt bendine göre işçinin, işveren veya onun aile üyelerinden birinin şeref ve namusuna dokunacak sözler sarf etmesi veya buna yönelik davranmast ya da şeref ve haysiyet kırıcı asılsız ihbar ve isnatlarda

88 Kabul Tarihi: 06.04.2016 RG. Tarihi: 20.04.2016

89 Ayrıntılı bilgi için bkz. Birben, Erhan: "İşçinin Özel Yaşamı Nedeniyle İş Sözleşmesinin Feshi”, İş Hukukunda Genç Yaklaşımlar II, On İki Levha Yayıncılık, İstanbul, Ekim 2016, ss. 135-169, s. 143-149.

90 Dolandırıcıllk suçu ile ilgili ayrıntılı bilgi için bkz. Tezcan/Erdem/Önok, s. 806-846; Özbek/Doğan/Bacaksız, s. 709-732;

91 Özel belgede sahtecilik suçu için bkz. Tezcan/Erdem/Önok, s. 971-974; Özbek/

Doğan/Bacaksız, s. 860-863. 
bulunması işverenin "ahlak ve iyiniyet kurallarına uymayan haller ve benzerleri" kapsamında iş sözleşmesini derhal haklı nedenle feshedebilmesi imkânı sağlayacaktır. Madde 25/II'de örnekseyici sayım olduğu kabul edildiğinden bu söz ve davranışların sadece işverene karşı değil işveren vekiline karşı gerçekleştirilmesinde de haklı fesih sebebi olacağ 1 belirtilmektedir ${ }^{92}$. Yargıtay da bu yönde karar vermiş ve işyerinde bölüm şefine hakareti bu kapsamda kabul etmiştir ${ }^{93}$.

Madde metnindeki aile üyeleri ifadesi kapsamına ise, "işverenin eşi, çocukları, anne-babası ve kardeşleri"nin dâhil edilebileceği doktrinde belirtilmektedir ${ }^{94}$.

İşK. m. 25/II-b açısından önemli bir husus, işçinin ifade özgürlüğü kapsamında yapmış olduğu eleştiri ve açıklamaların bu kapsamda değerlendirilememesidir $^{95}$. Ayrıca işçinin ihbar ve isnatları asılsız ise haklı nedene konu edilebilecektir. Aksi halde buna dayanarak işveren, işçinin iş sözleşmesini haklı nedenle feshedemeyecektir ${ }^{96}$.

Uygulamada uyuşmazlıklara sebep olabilecek diğer durum ise, hakl1 nedenin varlığının ispatıdır. Örneğin, işverene ait bilgisayar ve e-mail adresiyle yaptığı özel yazışmalarda işçinin işverene hakaret teşkil eden ifadeler kullanması veyahut işverenle bağlantısı olmayan bir bilgisayar ve internette yapmış olduğu yazışmalar ya da sosyal medya araçlarında bu ifadelere yer vermesi halinde, öncelikle kontrol edilmesi gereken işverenin bu bilgileri hukuka uygun bir şekilde elde edip etmediğidir. Eğer hukuka aykırılık varsa bu şekilde elde edilen delilin "delil yasakları" kapsamında dikkate alınmaması gerekecektir ${ }^{97}$. Ancak hukuka aykırı şekilde edinilen bir delil, yasak

Eyrenci/Taşkent/Ulucan, s. 250; Süzek, s. 669; Mollamahmutoğlu/Astarlı/Baysal, s. 238-239.

Bkz. Y. 9. HD., 04.03.1999, 1999/1866 E., 1999/4119 K., www.kazanci.com, (E.T.:15.04.2020).

Demir, s. 408. Ayrıntılı bilgi için bkz. Odaman, Ahlak ve İyiniyet Kuralları ve Benzerleri, s. 95-97; Arslan Durmuş, s. 58-59.

95 Tunçomağ/Centel, s. 224; Süzek, s. 668; Öktem Songu, İfade Özgürlüğü, s. 637-638.

96 Tunçomağ/Centel, s. 224; Süzek, s. 669; Demir, s. 408; Mollamahmutoğlu/Astarlı/ Baysal, s. 239; Senyen Kaplan, İş Hukuku, s. 283; Alp, Whistleblowing, s. 405; Öktem Songu, İfade Özgürlüğü, s. 641-642. Asılsız isnada yönelik karar için bkz. Y. 9. HD., 30.9.2004, 2004/4860 E., 2004/21081 K., www.kazanci.com, (E.T.:25.06.2020).

İnternet ve e-postaya müdahale ile elde edilen delillerle ilgili ayrıntılı bilgi için bkz. Öktem Songu, s. 1081-1086. Yargitay, işverene ait bilgisayarları ve elektronik postaları kullanarak işçinin yaptığı özel yazışmalarda işverene karşı hakaret niteliğinde ifadeler kullanmasını İşK. m. 25/I'in II. bendi uyarınca haklı neden olarak kabul etmiştir, [Y. 9. HD., 13.12.2010, 2009/447 E. , 2010/37516 K. , www.kazanci.com, (E.T.:15.04.2020)]. Doktrinde de bu karar yerinde bulunmuş ancak, bu yönde kararların işverenin e-posta- 
delil olarak kabul edilse ve gerekçedeki değerlendirmede buna yer verilmese de, özellikle iş mahkemelerinde bu deliller hâkimin kanaatini etkileyebildiğinden, hukuka aykırı olduğunu bilmesine rağmen davanın taraflarının bu yasak delilleri dosyalarına eklediği uygulamada görülmektedir.

Ceza Kanunu ile İş Kanunu metinleri karşılaştırıldığında bu alt bentteki haklı nedenin TCK m. 125 kapsamında hakaret suçunu oluşturabileceği görülecektir. Çünkü suçun kanundaki tanımına bakıldığında birine onur, şeref ve saygınlığın rencide edebilecek nitelikte somut bir fiil veya olgu isnat eden veya sövmek suretiyle bir kimsenin onur, şeref ve sayginlığina saldıran kişi hakaret suçunu işlemiş olacaktır ${ }^{98}$.

2005 tarihinde TCK m. 125 kanun metnindeki "yakıştırmada bulunmak" ifadesi çıkarılmıştır". Ama bunun madde uygulamasında bir değişikliğe sebep olmayacağı; bu kavrama ayrıca yer verilmesine gerek olmadığı için maddeden çıkarıldığ ifade edilmiştir ${ }^{100}$. Bu düşünceye göre onur, şeref ve saygınlı̆̆ını rencide edebilecek nitelikte bir yakıştırmanın bu madde kapsamında kabul edilmesi gerekecektir.

Burada işverenin gıyabında gerçekleşen hakaretin suç teşkil etmesi için en az üç kişinin konuya dâhil olması aranmıştır. Dolayısıyla işçinin sadece bir arkadaşına işvereninin şeref ve namusuna dokunacak sözler söylemesi haklı neden olabilecek ama hakaret suçu niteliği taşımayacaktır. Bu "en az üç kişi” kapsamına doğal olarak hakarete uğrayan kişinin kendisi (mağdur ${ }^{101}$ ve fail girmez. Ayrıca yasal olarak sırrı saklamak zorunda olanların da en az üç kişi kapsamına dâhil edilemeyeceği kabul edilmiştir. Üç kişi şartının gerçekleşmesi için konuya dâhil olan kişilerin hakaretin anlamını kavrayabilmiş olmaları gerekir. Bu sebeple sağırlık, sarhoşluk, akıl hastalığı, yaş küçüklüğü, kullanılan dili bilmeme gibi durumlar varsa söz konusu kişiler en az üç kişi şartını oluşturamaz. Temyiz kudreti mutlak bir şekilde ortadan kalkmış olan kişiler için de bu durum evleviyetle geçerli olacaktır ${ }^{102}$. Bunların yanı sıra en az üç kişi şartını sağlayacakların birlikte olmaları ve hakareti aynı anda öğrenmeleri gerekmez ${ }^{103}$.

lara müdahalesinin hukuka uygunluğuna bakılarak verilmesinin gerekliliği de belirtilmiştir, (Süzek, s. 669, dpn. 10) .

Hakaret suçu ile ilgili ayrıntılı bilgi için bkz. Yurtcan, Erdener: Yargıtay Kararları Işı̆̆ında Hakaret Suçları, 4. Bası, Seçkin Yayıncılık, 2019; Kocaoğlu, Serhat Sinan: Hakaret Suçu, Seçkin Yayıncılık, Ankara, Mart 2019.

99 9/6/2005 tarihli ve 5377 say1l Kanunun 15 inci maddesiyle.

100 Yurtcan, s. 15.

101 Y. 15. CD. 15.09.2014, 2013/23027 E., 2014/14671 K., (Yurtcan, ss. 46-50, s. 47).

102 Tezcan/Erdem/Önok, s. 613-614; Yurtcan, s. 13; Kocaoğlu, s. 141-142.

103 Y. 15. CD. 07.10.2015, 2015/4014 E., 2015 /29599 K., (Yurtcan, ss. 61-64, s. 61). 
Hakaret suçunun soruşturulması ve kovuşturulması ise mağdurun, konumuz açısından bakarsak işverenin şikâyetine bağlı olacaktır (TCK m. $131)^{104}$.

İşK. m 25/II-b'de asılsız ihbar ve isnatlarda bulunulması ifadesine de yer verilmiştir. Bu durumda da TCK m. 271'deki "suç uydurma suçu" da gerçekleştirilmiş olabilir. Ceza düzenlemesine göre, "İşlenmediğini bildiği bir suçu, yetkili makamlara işlenmiş gibi ihbar eden ya da işlenmeyen bir suçun delil veya emarelerini soruşturma yapılmasını sağlayacak biçimde uyduran kimse" suç uydurma suçu işlemiş olmaktadır.

Yine belirtmek gerekir ki, tespit ettiğimiz üzere İşK. m. 25/II-b kapsamındaki işçinin söz ve davranışlarının suç teşkil etmesi mümkünse de, bu haklı nedenle fesih için bir zorunluluk değildir ${ }^{105}$.

\section{3. İşçinin Cinsel Tacizde Bulunması}

İşK. m. 25/II-c alt bendinde, işçinin işverenin başka bir işçisine karş1 cinsel tacizde bulunması haklı neden olarak kabul edilmiştir. Burada işyeri ifadesine yer verilmediğinden tacizin nerede gerçekleştiği önem taşımamaktadır ${ }^{106}$. Söz konusu işçilerin aynı işyerinde çalışıyor olması dahi gerekmediği kabul edilir ${ }^{107}$. Dahası özel olarak düzenlenmese de işçinin bir müşteriyi taciz etmesi de haklı neden olarak görülmüştür. Ama tacize ilişkin bu hüküm olmasa da işçinin müşteriyi taciz etmesi karşısında, İşK. m. 25/IIe alt bendi (işşinin doğruluk ve bağlılığa uymayan davranışları) ya da f bendi (işyerinde suç işlenmesi) uyarınca da haklı neden gündeme gelebilir. Zaten böyle bir olayda Yargıtay cinsel taciz ile ilgili II-c'yi değil İşK. m. 25/II-e'yi dayanak göstermiştir ${ }^{108}$. Sonuç olarak sadece "işverenin bir başka işçisi" ifadesine yer verilmişse de, işyerinde herhangi bir kişiye, işçi sıfatı olmayan

\footnotetext{
104 Takibi şikâyete bağlı suçlarda suçu bildirmeme suçu kapsamında bir bildirim yükümlülüğü olup olmadığı ise tartışmalıdır. Bkz. II. A. Suçu Bildirmeme Suçu, dpn. 33.

105 Tunçomağ/Centel, s. 219; Demir, s. 408. Bkz. I. Haklı Nedenle Fesihlerde Ceza Mahkemesi Kararı Gerekliliği ve Ceza Yargılamasının İş Mahkemesi Kararlarına Etkisi

106 Tunçomağ/Centel, s. 224; Süzek, s. 669-670; Mollamahmutoğlu/Astarlı/Baysal, s. 239, Senyen Kaplan, s. 284; Savaş, s. 82; Arslan Durmuş, s. 70; Yamakoğlu, s. 136.

107 Mollamahmutoğlu/Astarlı/Baysal, s. 239; Arslan Durmuş, s. 69.

108 Bkz. Y. 9. HD. 21.11.2017, 2017/7241 E. , 2017/18767 K. , www.hukukmedeniyeti.org, (E.T.: 04.04.2020). Benzer şekilde şoförün yolcuyu tacizi de İşK m. 25/II- e kapsamında haklı neden kabul edilmiştir, Bkz. Y. 22. HD., 19.10.2015, 2015/24569 E., 2015/28955 K., (Astarlı, Muhittin: “İş İlişskisinin Sona Ermesi ve Kıdem Tazminatı”, Yargıtay'ın İş Hukuku ve Sosyal Güvenlik Hukuku Kararlarının Değerlendirilmesi 2015, Onikilevha Yayınc1lı, İstanbul, Kasım 2017, ss. 211-383, s. 247).
} 
çırak, stajyer ya da alt işvereninin işçisine cinsel tacizde bulunulması da bu bent kapsamında kabul edilmiştir ${ }^{109}$.

Maddede, işçinin, işverene ya da işverenin ailesine cinsel tacizde bulunmasına yönelik bir ifadeye de yer verilmemiştir. Çünkü işverene ve ailesine cinsel tacizde bulunulması İşK. m. 25/II-b alt bendi kapsamında şeref ve namusa dokunacak söz ve davranış olarak değerlendirileceğinden derhal feshe olanak sağlayabilecektir.

Aslında c alt bendine yer verilmeseydi de, "işverenin bir işçisinin bir başka iş̧̧isine cinsel tacizde bulunmasının haklı neden teşkil edeceği", aşağıda irdeleyeceğimiz d alt bendi uyarınca "sataşma" haklı nedenle feshine imkân sağladığından evleviyetle mümkün görülebilirdi ${ }^{110}$. Ama konunun hassasiyetinden dolayı ayrı bir alt bent olarak düzenlenmiştir ${ }^{111}$.

Konunun hassasiyeti Türk Ceza Kanunu düzenlemelerinden de anlaş1lmaktadır. Çünkü TCK m. 105/II-c bendinde, "aynı işyerinde çalışmanın să̆ladiğ kolaylıktan faydalanmak suretiyle suçun işlenmesi" cinsel tacizin, TCK m. 102/III-b bendinde ise "...hizmet ilişsisinin sağladĭ̆ nüfuz kötüye kullanılmak suretiyle işlenme" cinsel saldırı suçunun ağırlaştırıcı sebepleri olarak kabul edilmiştir. Bu durumlarda her iki suçta ceza $1 / 2$ oranında arttırılacaktır. Ayrıca olay sebebiyle mağdur, işinden ayrılmak durumunda kaldıysa da cinsel tacizin cezas 1 yıldan daha az olamayacaktır. Her ne kadar ilk bakışta bu ağırlaştırıcı hallerin, işçinin iş sözleşmesini haklı nedenle feshetmesi kapsamında işverenin cinsel tacizinde (iş ilişkisindeki konumu ve hiyerarşik ilişki sebebiyle) gerçekleşeceği düşünülebilirse de, elbette işçiler açısından da (Ör: işçinin bir başka işçiye cinsel tacizde bulunmasında) söz konusu olabilecektir.

Bir fesih nedeninin geçerli mi haklı mı ve haklı nedense hangi kapsamda olduğunun tespitinin öneminden dolayı, her ne kadar "kazuistik

109 Eyrenci/Taşkent/Ulucan, s. 250-251; Arslan Durmuş, s. 68; Yamakoğlu, s. 135-136. İşyerindeki stajyer kız öğrenciye karşı uygunsuz hareketlerin İşK m. 25/I II-c alt bendi kapsamında kabul edilebileceğinin belirtildiği karar için bkz. Y. 9 HD., 19.6.2006, 2006/13620 E., 2006/17779 K., www. kazanci.com (E.T.:13.04.2020).

110 Zaten 1475 sayılı İş Kanunu döneminde cinsel taciz açıkça haklı neden olarak sayılmamıştı ve yine de haklı nedenle fesih geçerli kabul ediliyordu. Bkz. Y. 9. HD., 10.11.2005, 2005/6471 E., 2005/35643 K., (www.kazanci.com, E.T.:15.06.2020)

111 İş Hukuku'nda cinsel taciz ve somut örnekleri ile ilgili daha ayrıntılı bilgi için bkz. Bakırcı, Kadriye: İşyerinde Cinsel Taciz, Yasa Yayıncılık, İstanbul, 2000; Bilgili, Abbas: İş Hukuku Açısından İş Yerinde Cinsel Taciz, Karahan Kitabevi, Adana, 2010; Köseoğlu, Ali Cengiz: İş Sözleşmesinin İşçiden Kaynaklanan Nedenlerle Bildirimli Feshi, Beta Yayıncılık, İstanbul, 2011, s. 241-250; Arslan Durmuş, s. 66-68; Erkanlı Başbüyük, Betül: "İş Görmekten Kaçınma Sebebi Olarak İşyerinde Cinsel Taciz", Legal İSGHD, Y1l: 2019, C.16, S.61, (Cinsel Taciz), ss. 127-180, s. 129-144. 
yöntem" uygulama bakımından sorunlu bir kanun yapma tekniği olsa da, hukukumuz için m. 25/II-c alt bendinin Kanunda düzenlenmiş olmasının yerinde olduğu düşüncesindeyiz. Bu sebeple işverene ve ailesine yapılacak cinsel taciz $\mathrm{b}$ alt bendi kapsaminda zaten haklı neden olarak kabul edilebilirse de, cinsel tacize ilişkin II-c'ye "işverene, onun ailesine ve başka işçilerine cinsel tacizde bulunması" şeklinde genel bir ifadeye yer verilmesi daha düzenli olabilir. Ayrıca hukukumuzda Alman Hukuku'ndaki gibi olağanüstü fesih için "önemli sebep (wichtiger Grund)" şeklinde genel ve soyut bir çerçeve belirlemek yerine haklı nedenler ayrıntılı olarak düzenlendiğinden, bentte sadece cinsel tacize değil TCK'da daha ağır bir suç olarak düzenlenmiş cinsel saldırıya da yer verilebilirdi ${ }^{112}$. Ama mevcut hükümle, daha hafif bir cezayı gerektiren cinsel taciz suçu haklı neden olarak sayıldığından, hem "şeref ve namusa dokunacak söz ve davranışlar" hem de “cinsel taciz"e ilişkin hüküm uyarınca daha ağır cezanın öngörüldüğü cinsel saldırı evleviyetle haklı neden teşkil edecektir.

"Cinsel taciz suçu” Türk Ceza Kanunu'nun 105. maddesinde düzenlenmiştir. Burada cinsel tacizin bir tanımına ve kapsamının ne olacağına açıç̧a yer verilmemiştir ${ }^{113}$. Ancak gerekçede açıklanmaya çalışılmıştır. Buna göre cinsel taciz, kişinin vücut dokunulmazlığının ihlali niteliği taş1mayan cinsel davranışlarla gerçekleştirilebilir. Başka ifadeyle bir kişinin, cinsel açıdan ahlaka aykırı olarak vücut bütünlüğü ihlal etmeksizin rahatsız edilmesine cinsel taciz denecektir. Bu doğrultuda eski Ceza Kanunu'ndan da yola çıkarak doktrinde cinsel tacizin söz atma ve sarkıntılık durumlarını kapsadığ1 belirtilirken, 2014 yılında 6545 sayılı Kanunla Türk Ceza Kanunu'nda yapılan değişikliklerle birlikte bu görüş değişmiştir ${ }^{114}$. Zira 102. maddedeki değişiklikle birlikte "sarkıntılık" bir cinsel saldırı suçu olarak kabul edilmiştir.

İşK. m. 25'de ve TCK'da cinsel tacizin tanımı yapılmamıştır; ancak 6701 sayılı Türkiye İnsan Hakları ve Eşitlik Kurumu Kanunu ${ }^{115}$ 'nun 2/j maddesinde taciz tanımı yapılmış ve onun bir türü olarak cinsel tacize yer verilmiştir. Bu hükme göre "psikolojik ve cinsel türleri de dâhil olmak üzere

112 TCK m. 102 'de cinsel saldırı suçu kapsamında beş yıldan on yıla kadar ya da iki yıldan beş yıla kadar cezaya mahkûmiyet söz konusu iken, TCK m. 105'deki cinsel taciz suçunun basit hali için altı aydan üç yıla kadar ceza düzenlenmiştir.

113 Cinsel taciz suçu ile ilgili ayrıntılı bilgi için bkz. Tezcan/Erdem/Önok, s. 459-474; Özbek/Doğan/Bacaksız，s. 388-400; Koca, Mahmut/ Üzülmez, İlhan: Türk Ceza Hukuku Özel Hükümler, 6. Baskı, Adalet Yayınevi, Ankara, Ekim, 2019, s. 377-384; Özen, s. 451-466; Yokuş Sevük, s. 153-163.

114 Özbek/Doğan/ Bacaksız, s. 391; Koca/Üzülmez, s. 378.

115 R.G. Tarihi: 20/4/2016 R.G. Sayısı: 29690 
bu Kanunda sayllan temellerden birisine dayanılarak, insan onurunun çiğnenmesi amacını taşlyan veya böyle bir sonucu doğuran ylldırıcı, onur kırıcı, aşağılayıcı veya utandırıcı her türlü davranış" taciz olarak nitelendirilecektir. Ayrıca aynı Kanunda taciz ve dolayısıyla cinsel tacizin bir ayrımc1lık türü olduğu belirtilmiştir (m.4/I-g).

TCK m. 102'de ise "cinsel saldırı suçu” düzenlenmiştir. Buna göre cinsel davranışlarla bir kimsenin vücut dokunulmazlığını ihlâl eden kişi cinsel saldırıda bulunmuş olacaktır. Ancak "cinsel davranış"ın ne anlama geleceğine madde metninde yer verilmemiştir. Ama TCK m. 102'nin gerekçesinde "kişinin vücudu üzerinde gerçekleştirilen, cinsel arzuları tatmin amacına yönelik ve fakat cinsel ilişkiye varmayan cinsel davranışlar" ifadesi kullanılmıştır ${ }^{116}$. Yukarıda belirttiğimiz üzere TCK m. 102'de yapılan değişiklik sonrası, cinsel saldırının düzenlendiği bu madde de "sarkıntılık" ifadesi karşımıza çıkar. Sarkıntılık boyutundaki davranışlar da cinsel saldırı suçu teşkil edecek ancak daha az bir cezaya hükmedilecektir. Böylece yapılan değişikliklerle birlikte "cinsel taciz suçu kapsamındaki cinsel amaçlı rahatsız edici fiillerin", sarkıntılık boyutuna ulaşmayan sırnaşıkça hareketler ve söz atma ile sınırlı olduğu sonucu çıkarılmıştır ${ }^{117}$.

Cinsel saldırı gibi sarkıntılık ifadesine de İşK m. 25'de yer verilmemiştir. Ama sonuç olarak, TCK kapsamında öngörülen yaptırımlara göre değerlendirildiğinde sarkıntılık, cinsel saldırı boyutuna ulaşmamış ama cinsel tacizden daha ağır bir cinsel davranış olarak nitelendirilebilecektir ${ }^{118}$. $\mathrm{Bu}$ sebeple de Kanunda açıkça yazılmamışsa da sarkıntılık evleviyetle haklı neden teşkil edecektir.

Doktrinde ve Yargitay kararlarında cinsel taciz ve cinsel saldırı kavramlarının ayrılmasında çeşitli değerlendirmeler yapılmaktadır ${ }^{119}$; ama "bir davranışın cinsel saldırı $\mathrm{m} 1$ cinsel taciz mi olduğunun tespiti” iş sözleşme-

116 Cinsel saldırı suçu ile ilgili ayrıntılı bilgi için bkz. Tezcan/Erdem/Önok, s. 373-424; Özbek/Doğan/ Bacaksız, s. 319-351; Koca/Üzülmez, s. 322-350; Özen, s. 349-396; Yokuş Sevük, s. 77-111).

117 Özbek/Doğan/Bacaksız, s. 391.

118 TCK m. 102/I: "Cinsel davranışlarla bir kimsenin vücut dokunulmazlığını ihlâl eden kişi, mağdurun şikâyeti üzerine, beş yıldan on yıla kadar hapis cezası ile cezalandırılır. Cinsel davranışın sarkıntılık düzeyinde kalması hâlinde iki yıldan beş yıla kadar hapis cezast verilir".

TCK m. 105/I: "Bir kimseyi cinsel amaçlı olarak taciz eden kişi hakkında, mağdurun şikayeti üzerine, üç aydan iki yıla kadar hapis cezasina veya adli para cezasina fiilin çocuğa karşı işlenmesi hâlinde altı aydan üç yıla kadar hapis cezasına hükmolunur".

119 Ayrıntılı bilgi için bkz. Özbek/Doğan/Bacaksız, s. 319-393; Koca/Üzülmez, s. 380381. 
sinin feshi bakımından farklılık doğurmayacağından burada yer verilmeyecektir. Bununla birlikte aşağıdaki bir diğer başlıkta ele alacağımız üzere, bir davranışın sataşma olup olmadığının tespiti, somut olaydaki davranışın ağırlığına göre haklı neden değil de geçerli neden sayılmasını sağlayabileceğinden "sarkıntılık-cinsel taciz" ile "sataşmanın" arasındaki fark önemli olacaktır. Ayrıca sataşma ayrı bir alt bend olarak düzenlendiğinden, cinsel taciz hükmü kapsamında değerlendirilebilecek sarkıntılık ile sataşmanın farkına da değinmek gerekir.

İşçinin eyleminin ağır olduğu ve sataşma kapsamında da sayılsa haklı nedene sebep olacağı bir somut olayda, davranışın "sataşma" mı yoksa "cinsel taciz" düzenlemesi uyarınca $\mathrm{m} ı$ haklı neden teşkil edeceğinin önemli olmayacağı düşünülebilir. Çünkü her ikisi de "ahlak ve iyi niyet kurallarına uymayan haller ve benzeri durumlar" kapsamındadır ve işçi açısından hukuki sonuçları aynı olacaktır. Ama aslında konunun toplumsal açıdan hassasiyeti düşünüldügünde işçinin $\mathrm{c}$ bendindeki cinsel taciz mi yoksa $\mathrm{d}$ bendindeki sataşma düzenlemesine göre mi feshedildiği diğer başvuracağ işlere alınması bakımından etkili olabilecektir. Bu sebeple her ne kadar hukuki sonuçlar bakımından fark olmasa da, somut olaydaki davranışların değerlendirilmesi ve bu doğrultuda hangi haklı nedene dayanılabileceğinin tespiti önem arz edecektir ${ }^{120}$.

Son olarak İşK. m 25/II-c bakımından belirtmemiz gereken husus, İş Kanunu m. 24 ve m. 25 'de açıkça yer verilmemişse de yargı kararlarında hem işveren hem de işçinin başvurabileceği haklı neden olarak kabul edilen mobbing (psikolojik taciz)dir.

Mobbing ile ilgili İş Kanunu'nda bir düzenleme bulunmamakla birlikte; aynı anlama geldiği kabul edilen ve birbiri yerine kullanılan "psikolojik taciz" kavramına, daha önce de değindiğimiz TBK m. 417'deki işçiyi gözetme borcu kapsamında yer verilmiştir. Bu madde uyarınca işveren, işçilerinin psikolojik tacize uğramamaları ve uğradılarsa da daha fazla zarar görmemeleri için gereken tedbirleri almak zorundadır. Türk Borçlar Kanunu'nun ardından 2011/2 sayılı "İşyerlerinde Psikolojik Tacizin (Mobbing) Önlenmesi Genelgesi ${ }^{121}$ " yayınlanmıştır. Burada psikolojik tacizin ne olduğu aydınlatılmaya çalışılmış ve "kasitlı ve sistematik olarak belirli bir süre çallşanın aşăğlanması, küçümsenmesi, dışlanması, kişiliğinin ve saygınlı̆̆ının zedelenmesi, kötü muameleye tabi tutulması, yıldırılması ve benzeri şekillerde" ortaya çıktığı ifade edilmiştir.

120 Ayrıca bkz. III. A. 4. İşçinin Sataşması ve Sarhoşluğu
121 R.G. Tarihi: 19.03.2011 R.G. Sayısı: 27879 
Ayrıca yukarıda yer verdiğimiz, Türkiye İnsan Hakları ve Eşitlik Kurumu Kanunu 2/j'deki tacizin tanımında "psikolojik taciz"in bir taciz türü olduğu belirtilmiştir. Burada genel anlamda psikolojik tacizin yanı sıra, aynı Kanunun 2/g maddesinde, kavramın ayrımcılık temelli iş hukuku yansıması olarak ifade edebileceğimiz "işyerinde yıldırma"ya yer verilmiştir. Düzenlemeye göre "Kanunda sayılan ayrımcılık temellerine dayanılarak kişiyi işinden soğutmak, dışlamak, biktırmak amacıyla kasitlı olarak yapılan eylemler" işyerinde yıldırma olarak tanımlanmıştır.

Belirttiğimiz düzenlemelerden yola çıkılarak Yargıtay ve Bölge Adliye Mahkemeleri kararlar1 ${ }^{122}$ 1şığında mobbing, "işçinin manevi kişiliğine karşı işveren, işveren vekili veya diğer işçiler tarafından ${ }^{123}$ gerçekleştirilen, süreklilik gösterip sistematik hale gelen, kötü muamele, aşağılama, dışlama vb. biçimde ortaya çıkan, onur kırıcı, küçültücü ve yıldırıcı (bezdirici), genellikle işçinin istifasını sağlama amacını taşıyan bir çeşit psikolojik şiddet" olarak ifade edilebilecektir ${ }^{124}$.

Y. HGK, 25.1.2017, 2015/9-461 E. , 2017/127 K.; Bursa BAM, 3. HD., 23.05.2019, 2018/4050 E., 2019/1292 K., Antalya, BAM, 9. HD., 28.11.2019, 2019/1778 E., 2019/2009 K., (www.kazanci.com, E.T.:10.09.2020).

123 Burada mobbing işverenin haklı nedenle feshedebilmesi bakımından incelenmektedir. Mobbing ayrıca işçi açısından da haklı neden teşkil edecektir. Bkz. III. B. 2. İşverenin Şeref ve Namusa Dokunacak Söz ve Davranışları ya da Cinsel Tacizde Bulunması ve III. B. 4. İçinin Diğer İşçi veya Üçüncü Kişilerce Cinsel Tacize Uğraması.

124 Süzek, s. 389; Mollamahmutoğlu/Astarlı/Baysal, s. 186; Savaş Kutsal, F. Burcu: "İşyerinde Psikolojik Taciz (Mobbing), Toprak İşveren Dergisi, Y11: 2015 S.105, Mart 2015, (Makale Format1), ss. 1-14, (www.toprakisveren.org.tr/140-isyerinde-PsikolojikTaciz-MOBBiNG.Makale, E.T.: 11.09.2020), s. 3. Mobbing (psikolojik taciz) ile ilgili ayrıntılı bilgi için bkz.; Güzel, Ali/Ertan, Emre: "İşyerinde Psikolojik Tacize (Mobbinge) Hukuksal Bakış: Avrupa Hukuku ve Karşılaştırmalı Hukuk”, Legal İSGHD, Y11: 2007, C.4, S.14, ss. 509-549; Bayram, Fuat: "Türk İş Hukuku Açısından İşyerinde Psikolojik Taciz (Mobbing)", Legal İSGHD, Y11: 2007, C. 4, S.14, ss. 551-574; Güzel, Ali/Ertan, Emre: "İşyeri Sendika Temsilcisine Yönelik Psikolojik Taciz ve Kötüniyet Tazminatı (Karar İncelemesi)", Çalışma ve Toplum Dergisi, 2008/1, S.16, (İnceleme), ss. 149-170; Güzel, Ali:“İş İlişkisinin Sona Ermesi ve Kıdem Tazminatı”, Yargıtay’ın İş Hukuku ve Sosyal Güvenlik Hukuku Kararlarının Değerlendirilmesi 2010, Kamu-İş, Ankara, Ekim 2012, ss. 133-284, s. 270-275; Keser, ss. 329-343; Büyükkılıç, Gül: "İş Hukuku Çerçevesinde İşyerinde Psikolojik Taciz (Mobbing) Olgusunun Değerlendirilmesi, ”, Legal İSGHD, Y11: 2012, C.9, S.33, ss. 89-160 Ünal, Canan: “Karşılaştırmalı Hukuk Işığında İşyerinde Psikolojik Tacizin İşverenin İşçinin Kişiliğini Koruma ve Eşit Davranma Borcu Kapsamında Değerlendirilmesi”, Legal İSGHD, Y11: 2013, C.10, S.37, ss. 33-73, Limoncuoğlu, Alp: "İş̧̧inin İş Sözleşmesini Psikolojik Tacize Dayalı Olarak Haklı Nedenle Feshinde Hak Düşürücü Sürenin Başlangıcı (Karar İncelemesi)”, Polat SOYER'e Armağan, DEÜHFD, Y11: 2013, C.15, Özel Say1, 2014, ss. 547-571, Taşkın, Ahmet: "İşyerinde Mobbingin Ceza Hukuku Bakımından Değerlendirilmesi”, Çalışma ve Toplum Dergisi, 2015/1, ss. 221-258, Hüseyinli, Namı/Aslan Atabay, Hatice: 
Mobbing, uygulamada çok çeşitli şekillerde karşımıza çıkabilir. İşçinin yüksek sesle azarlanması, dışlanarak yokmuş gibi davranılması, özel kutlama ve sosyal etkinliklere kasıtlı olarak davet edilmemesi, dış görünüşüyle alay edilmesi, sözünün kesilmesi, işçi hakkında asılsız söylentiler çıkarılması, sürekli eleştirerek iş yaptırılması, işçiye yetenek veya uzmanlık alanına girmeyen işler verilmesi, işçinin kendini göstermesinin engellenmesi, fikirlerinin asla dikkate alınmaması, işçiye hak ettiği yetkilerin verilmesinden kaçınılması, ağır ya da niteliksiz işler verilmesi, fiziksel şiddet tehdidinde bulunulması, anlamsız işler verilerek sürekli işçinin çalışma yerinin değiştirilmesi örnek olarak verilebilir ${ }^{125}$.

Hem tanımdan hem de verdiğimiz örneklerden anlaşıldığı ve Yargitay'ın da açıkça ifade ettiği üzere mobbingde, hedef alınan kişinin şerefine, kişiliğine, karakterine, inancına, değerlerine, yeteneklerine, tecrübelerine, birikimlerine, düşüncelerine, etnik kökenine, yaşam biçimine, kültür ve benzeri yönlerine bir saldırı söz konusu olacaktır ve saldırı, "dedikodu ve söylenti çıkarma, iftira atma, toplum önünde küçük düşürme, hafife alma, karalama, kötüleme ve yok sayma" gibi kişiyi zihinsel, ruhsal, fiziksel ve bedensel olarak etkileyebilecek eylemlerle yapilabilmektedir ${ }^{126}$. Ancak bu eylemler "süreklilik göstermeyen", "ara sıra münferit olarak meydana gelmiş" kaba, nezaketsiz veya etik dışı bir davranış mobbing olarak nitelendirilemeyecektir ${ }^{127}$.

Doktrinde bir işçinin başka bir işçiye karşı mobbing uygulamasının haklı neden teşkil ettiği genel olarak kabul edilmişse de ${ }^{128}$ hangi hüküm

"Psikolojik Tacizin İçtihatlar Işı̆̆ında Uygulamadaki Yeri”, İnönü Üniversitesi Hukuk Fakültesi Dergisi, Yıl: 2017, C.8, S.2, ss. 603-636; Baycık, Gaye: "İş İlişskisinin Kurulmas1, Hükümleri ve İşin Düzenlenmesi”, Yargıtay'ın İş Hukuku ve Sosyal Güvenlik Hukuku Kararlarının Değerlendirilmesi 2016, 2. Baskı, Onikilevha Yayıncılık, İstanbul, Kasim 2018, ss. 7-355, s. 252-278.

125 Süzek, ss. 389-390; Mollamahmutoğlu/Astarlı/Baysal, s. 186; Öktem Songu, Sataşma, s. 127-128. Bkz. Y. HGK, 25.09.2013, 2012/9-1925 E. , 2013/1407 K., Y. HGK, 16.1.2020, 2019/9-571 E., 2020/23 K., (www.kazanci.com, E.T.:10.09.2020). Ayrıca bkz. Doğan Yenisey, Kübra: "İş İlişkisinin Kurulması, Hükümleri ve İşin Düzenlenmesi”, Yargıtay'ın İș Hukuku ve Sosyal Güvenlik Hukuku Kararlarının Değerlendirilmesi 2013, 2. Bask1, Onikilevha Yayıncılık, İstanbul, Kasım 2017, ss. 7145, s. 89-92; Keser, s. 340-34.

126 Y. 22. HD. 26.6.2014, 2014/15971 E., 2014/19538 K.; Y. 22. HD. 31.5.2016, 2015/ 11958 E. , 2016/15623 K., (www.kazanci.com, E.T.: 21.09.2020)

127 Antalya, BAM, 9. HD., 28.11.2019, 2019/1778 E., 2019/2009 K., (www.kazanci.com, E.T.:10.09.2020).

128 İşçinin işverenin bir başka işçisine mobbing uygulamasının işverene haklı nedenle fesih imkânı vermeyeceği, bunun ne m. 25/II-c ne de m. 25/II-d kapsamına girdiği; bu durumda işverenin geçerli nedenle feshe (iş güvencesi kapsamında olmayan bir işçiyse 
kapsamında değerlendirileceği konusunda farklı görüşler mevcuttur. Her ne kadar "taciz" ortak noktası sebebiyle İşK. m. 25/II-c'ye dayandırmak gerekeceği düşünülebilirse de, doktrinde İşK. m. 25/II-c veya İşK. m. 25/II-b ${ }^{129}$ (şeref ve namusa dokunacak söz ve davranışlar) ya da İşK m. 25/II-d (sataşma) hükmüne dayandırılması gerektiği de ileri sürülmüştür. Kanaatimizce somut olaya göre bir değerlendirme yapılmalıdır. Mobbing teşkil edecek davranışlar cinsel bir nitelik taşıyorsa II-c, cinsel nitelik taşımıyor ise II-b ya da II-d ${ }^{130}$ kapsamında kabul edilebilecektir. Sonuçta hepsi m. 25/II kapsamında olacağından, hukuki sonuçlar bakımından bir farklılık doğurmayacaktır. Ancak sataşma mı yoksa cinsel taciz hükmüne mi dayandırılacağının tespitinde de belirttiğimiz gibi; psikolojik taciz söz konusuysa bunun "cinsel taciz hükmü (İşK m. 25/II-c) mü yoksa diğerleri (İşK m. 25/II-b ya da d) kapsamında $m ı$ kabul edileceğinin tespiti” toplum yapımız ve konunun hassasiyeti sebebiyle önem arz edecektir.

Tüm bu incelemeler sonunda İşK. m. 25/II-c kapsamındaki davranışların çok çeşitli suçlara karşılık gelebileceğini söylemek mümkündür. İlk olarak yukarıda ele aldığımız cinsel taciz ve saldırı suçları söz konusu olacaktır. Bunun yanı sıra çalışanın çocuk işçi olması durumunda "çocukların cinsel istismarı (TCK m. 103) suçu” da gündeme gelecektir ${ }^{131}$.

Mobbing (Psikolojik Taciz) aşağıda inceleyeceğimiz sataşma gibi açıkça suç olarak düzenlenmemiştir. Ama yukarıda yer verdiğimiz üzere mobbing, işyerinde bir çalışana yöneltilen, işveren veya diğer işçiler tarafindan sistematik şekilde tekrarlanan, kötü muamele, tehdit, şiddet, aşağılama gibi düşmanca davranışlarla ortaya çıkan psikolojik bir saldırı biçimi olduğundan; mobbingi oluşturan tutum ve davranışlar TCK'da yer alan bazı suçlara karşılık gelebilecektir ${ }^{132}$. İncelediğimiz tanım ve örneklere bakıld1-

süreli feshe) başvurabileceği aksi görüşü için bkz. Şen, Sabahattin: "Psikolojik Taciz ve İş Kanunu Boyutu”, Çimento İşveren Dergisi, Yı1: 2009, C.23, S.5, ss. 46-68, s. 60, 62.

Büyükkılıç, Gül: "İş Hukuku Çerçevesinde İşyerinde Psikolojik Taciz (Mobbing) Olgusunun Değerlendirilmesi, ”, Legal İSGHD, Y11: 2012, C.9, S.33, ss. 89-160, s. 137138.

130 Bozbel, Savaş/Palaz, Serap: “İşyerinde Psikolojik Taciz (Mobbing) ve Hukuki Sonuçları" TİSK Akademi, Yı1: 2007/I, C.2, S.3, 2007 /I, ss. 66-81, s. 76.

131 Cinsel suçlarlar ilgili ayrıntılı bilgi için bkz. Arslantürk, Mustafa: Türk Ceza Kanunu Uygulamasında Cinsel Suçlar, Güncellenmiş ve Genişletilmiş 3. Baskı, Seçkin Yayınc1lık, Ankara, Mart 2017.

132 Taşkın, s. 237. Bu durumu mobbingle mücadele bakımından uygun bulmayıp, mobbingin ayrı bir suç tipi olarak düzenlenmesinin gerektiği görüşü için bkz. Taşkın, s. 221. Mevcut Türk Ceza Kanunu hükümlerinin yeterli olduğu, mobbingin bağımsız bir suç olarak düzenlenmesi gerekmediği görüşü için bkz. Erdem, Mustafa Ruhan/Parlak, Benay: "Ceza Hukuku Boyutuyla Mobbing”, TBB Dergisi, S.88, 2010, ss. 261-286, s. 286. 
ğında mobbingin söz konusu olduğu durumlarda somut olaya göre yaralama (TCK, m. 86), cinsel saldırı (TCK m. 102), cinsel taciz (TCK m. 105), hakaret (TCK m. 125) gibi suçların oluşabilmesi mümkündür ${ }^{133}$. Ayrıca mobbing süreci içerisinde izlenen amaca ulaşmak için, mağdurun hukuka aykırı belirli bir davranışa zorlanması durumunda "cebir kullanma (TCK m. $108^{134}$ )" suçu oluşabilecektir. Yine mobbing kapsamında gerçekleştirilen birçok eylemin "kişilerin huzur ve sükûnunu bozma suçu" TCK m. $123^{135}$ de geçen "ya da aynı maksatla hukuka aykırı başka bir davranışta bulunulması" içerisine sokulabileceği belirtilmiştir ${ }^{136}$.

Ayrıca mobbing haklı nedeni kapsamında özel olarak ele almamız gereken suç ise eziyet suçu (TCK m. 96) dur. Çünkü eziyet kavramı, mobbing davranışı ile büyük benzerlikler taşımaktadır ve asıl önemlisi, mobbingi oluşturan eylemlerden biri değil mobbingin bütününün bir suç teşkil edecek olmasıdır.

TCK m. 96' da bir kimsenin eziyet çekmesine yol açacak davranışları gerçekleştiren kişinin iki yıldan beş yıla kadar hapis cezası alacağı düzenlenmiştir. Ayrıca eziyet suçunun "çocuğa", "beden veya ruh bakımından kendisini savunamayacak durumda bulunan kişiye", "gebe kadına", "üstsoy veya altsoya", "babalık veya analığa" ya da "eşe" karşı işlenmesi ise nitelikli hal olarak düzenlenip, bu durumlarda cezanın arttırılacağı öngörülmüştür.

Eziyet belirsiz bir kavramdır. TCK m. 96'da ne anlama geldiğine yer verilmemiştir; ancak madde gerekçesinde kavram açıklanmaya çalışılmıştır: "Eziyet olarak, bir kişiye karşı insan onuruyla bağdaşmayan ve bedensel veya ruhsal yönden acı çekmesine, aşağllanmasına yol açacak davranışlarda bulunulmasi gerekir. Aslinda bu fiiller de kasten yaralama, hakaret, tehdit, cinsel taciz niteliği taşıyabilirler. Ancak, bu fiiller, ani olarak değil, sistematik bir şekilde ve belli bir süreç içinde işlenmektedirler. Bir süreç içinde süreklilik arzeder bir tarzda işlenen eziyetin özelliği, iş̧ence gibi, kişinin psikolojisi ve ruh sağllğı üzerindeki tahrip edici etkilerinin olmasidır. Bu etkilerin uzun bir süre ve hatta hayat boyu devam etmesi, eziyetin

133 Ayrıca bkz. Erdem/Parlak, s. 272-280, Taşkın, s. 236-249.

134 TCK m. 108: "Bir şeyi yapması veya yapmamast ya da kendisinin yapmasına müsaade etmesi için bir kişiye karşs cebir kullanılması halinde, kasten yaralama suçundan verilecek ceza üçte birinden yarısına kadar artırılarak hükmolunur".

135 TCK m. 123: "Sirf huzur ve sükûnunu bozmak maksadıyla bir kimseye ısrarla; telefon edilmesi, gürültü yapılması ya da aynı maksatla hukuka aykırı başka bir davranışta bulunulması halinde, mağdurun şikayeti üzerine faile üç aydan bir yıla kadar hapis cezast verilir". 
bu kapsamda işlenen fiillere nazaran daha ă̆ır ceza yaptırımı altına alınmasinı gerektirmiştir ${ }^{\prime \prime 137}$.

Görüldüğü üzere eziyet ve mobbing kavramları birbiriyle örtüşmekte; adeta mobbing, eziyet suçunun bir alt kümesini oluşturmaktadır. İkisinde de davranışlar sistematik şekilde gerçekleştirilmeli, tek seferlik olmamalı ve bunlar psikolojik tahribe yol açmalıdır. Mobbing teşkil eden eylemler bir bütün olarak eziyet suçunu oluşturmaktadır ve bu sebeple mobbing açıkça suç olarak düzenlenmemişse de eziyet suçu kapsamında cezalandırılabilecektir. Böylece mobbing oluşturan davranışlar kendi içinde cezalandırılmasının ötesinde kişinin taşıdığı mobbing amacı da bir yaptırımla karşılaşabilecektir. Yargıtay da bu görüş doğrultusunda bir karar vermiştir ${ }^{138}$.

\section{4. İşçinin Sataşması ve Sarhoşluğu}

İşK. m. 25/II-d alt bendine göre işçinin işverene, işverenin aile üyelerinden birine ya da işverenin başka işçisine sataşmasl, işyerine sarhoş veya uyuşturucu madde almış olarak gelmesi ya da işyerinde bu maddeleri kullanması durumunda işveren haklı nedenle iş sözleşmesini feshedebilecektir. Madde metninde yer alan sataşma ifadesi, ne İş Kanunu'nda ne de başka Kanunlarda açıklanmıştır. Bu kavramın kapsamının ne olduğu Yargıtay kararları ve doktrindeki görüşler doğrultusunda tespit edilebilmektedir.

Sataşmanın sözlükte iki anlamı bulunur. İlk anlamı "bir kimseyi rahatsız edecek davranışta bulunmak, musallat olmak" ikinci anlamı da "sarkıntılık etmek"tir. Sarkıntılık ise "genellikle kadınlara sataşma, laf atma, rahatSız etme, huzur bozma, tasallut" demektir ${ }^{139}$. Sözlük anlamlarına bakıld1ğında sarkıntılık ve sataşma kavramlarının birbiri içine geçebileceği söylenebilir. Ama günlük yaşamda bile bu kavramların yanlışlıkla birbiri yerine kullanılması toplumun ahlak anlayışı sebebiyle problem çıkarabilecekken, işçinin hangi haklı nedenle sözleşmesinin sona erdirilebileceğindeki hatalı tespitin iş̧̧inin gelecekteki işe alımlarında sorun yaratmayacağını söylemek kanaatimizce mümkün olmaz.

137 Eziyet suçu ile ilgili ayrıntılı bilgi için bkz. Koca/Üzülmez, s. 303-320.

138 “...sanı̆̆ın, söz konusu kişiye tecrübesine ve iş yerindeki pozisyonuna uygun şekilde görev vermeyerek sirf sıkıntı vermek, onu rencide ve pasifize etmek kastıyla binanın bodrum katında şoförlerin kullandı $\breve{g}$, telefon ve bilgisayar gibi gereçlerin bulunmadiğ odada mesai yaptırmaya zorlamak suretiyle, belirli bir süre sistematik biçimde devam eden, değersizleştirme, yıldırma ve işten uzaklaştırmayı amaçlayan 'psikolojik saldırıya konu eylemleri'nin işleniş biçimleri ve sonuçlarına göre eziyet boyutuna vardığını bu sebeple yüklenen eylemlerin bir bütün halinde 5237 Sayll TCK'nun 96/1. maddesinde düzenlenen 'eziyet' suçunu oluşturduğu...", Y.8.CD., 1.3.2018, 2018/203 E., 2018/2245 K., (www.kazanci.com, E.T.: 21.09.2020). 
Doktrinde cinsel nitelikli davranışların bazı hallerde cinsel taciz bazı hallerde sataşma düzenlemesi uyarınca haklı nedenle feshedileceğinin kabulünün yerinde olacağı belirtilmiştir. Bu görüş, şehvet amaciyla vücuda temas varsa "sarkıntılık" in söz konusu olduğunun (cinsel saldırı) ve bunun sataşma $d$ alt bendi kapsamında değerlendirilmesinin; fiziksel temasın olmadığı ve cinsel anlam içeren sözlerin kullanıldığı ya da davranışlarda bulunulduğu durumların ise cinsel taciz hükmü kapsamında kabul edilmesinin daha yerinde olacağını söylemektedir. Ayrıca Yargıtay'ın emsal içtihatlarında geçen fesih bildirimindeki "sebeple bağll1ık ilkesi" gereğince, feshin hangi nedenle yapıldığının açıkça ortaya konulmasının önem arz ettiği vurgulanmıştır ${ }^{140}$. Fesih nedeninin açıkça ortaya konması gerektiği görüşüne katılmaktayız. Çünkü cinsel taciz düzenlemesini irdelerken belirttiğimiz üzere $^{141}$ kavramların nitelendirilmesi ve hangi haklı neden kapsamına gireceğinin tespiti uygulama açısından önemlidir. Bunlar teorik tartışmadan ibaret olarak görülmemelidir. Ama bununla birlikte, cinsel tacizin özel olarak düzenlendiğini de göz önünde bulundurduğumuzda, ceza hukuku bak1mından daha ağır bir kavram olan "sarkıntılık" olarak nitelendirilebilecek cinsel bir davranışın, toplum yapımız sebebiyle cinsel taciz düzenlemesi kapsamında bir haklı neden kabul edilmesinin daha yerinde olacağı düşüncesindeyiz.

Sataşmanın sözle ya da davranış şeklinde gerçekleşebileceğ $1^{142}$ ve hayat, sağlık, namus gibi kişinin maddi veya manevi bütünlügünü hedef alabileceği belirtilir ${ }^{143}$. Örneğin, bir işçinin aynı işyerindeki diğer iki işçiyle birlikte duygusal ilişki yaşayıp, bu ortaya çıktıktan sonra duygusal ilişki yaşadığı işçiler hakkında konuşması ve bu konuşmaların yayılması olayında, işverenin İşK. m. 25/II-d kapsamında işçinin iş sözleşmesini feshetmesi hukuka uygun bulunmuştur ${ }^{144}$. İşçinin somut olaydaki bu davranışının toplumsal ve etik yönden onaylanamayacağı kabul edilmiştir ${ }^{145}$. Yargıtay kararlarında çeşitli şekillerde "sataşma" açıklanmaya çalışılmıştır. 9. Hukuk Dairesi, "sataşma"nın tehdit ve hakaret içeren sözler söyleme, etkili eylemde

\footnotetext{
140 Öktem Songu, Sataşma, s. 118.

141 Bkz. III. A. 3. İşçinin Cinsel Tacizde Bulunması

142 Süzek, s. 670, Demir, s. 409, Senyen Kaplan, İş Hukuku, s. 284, Ergin, ss. 71-87, s. 75, Öktem Songu, Sataşma, s. 120.

143 Senyen Kaplan, 284, Öktem Songu, Sataşma, ss. 114-115.

144 Y. 7. HD.,18.02.2014, 2013/25515 E., 2014/4086 K., [Çalışma ve Toplum Dergisi, 2015/1, S.44, (www.calismatoplum.org, E.T.:15.09.2020)].

145 Engin, Murat: “İş İlişkisinin Sona Ermesi ve Kıdem Tazminatı”, Yargıtay’ın İş Hukuku ve Sosyal Güvenlik Hukuku Kararlarının Değerlendirilmesi 2014, 2. Bask1, Onikilevha Yayıncıl1k, İstanbul, Kasım 2017, ss. 131-193, s. 159.
} 
(darp) bulunma ${ }^{146}$ gibi davranışlar olarak ortaya çıkacağını belirtmektedir ${ }^{147}$. 22. Hukuk Dairesi ise "yasaya göre 'sataşma'nın, sadakat borcuna aykırılığın özel bir hali olarak kabul edildiği ve söz veya fiili tecavüz anlamına gelen bir hareket olduğu"na hükmetmiştir ${ }^{148}$.

22. Hukuk Dairesi'nin bir kararının ${ }^{149}$ karşı oy yazısında ise, "sataşmanın bir kimseyi rahatsız edecek davranışlarda bulunmak veya bir kimseye musallat olmak anlamına geleceği", "bir kimsenin diğer bir kimseyi belli bir şekilde söz söylemeye veya belli şekilde davranmaya zorlayacak şekilde söz, tutum, davranış veya fiille rahatsız etmesinin sataşma olarak değerlendirileceği" ve "sataşma kavramının içinde bir başkasına yönelik maddi veya manevi bir haksızlık söz konusu olduğu bu sebeple sataşılan kimsenin haksızlığa uğradığı" hususlarına yer verilmiştir.

Sataşma nitelendirmesinin nasıl yapılacağının anlaşılması önemlidir. Çünkü bunun sonucuna göre somut olayda haklı mı yoksa geçerli neden mi olduğuna kararı verilir. Örneğin, sataşma niteliğinde değilse, diğer işçilerle devamlı ve gereksiz tartışmaya girişmek, iş arkadaşları ile ciddi geçimsizlik göstermek haklı değil geçerli neden sayılacaktır ${ }^{150}$. Dahası Yargıtay'ın, somut olaydaki işçinin davranışını sataşma olarak nitelendirip işyeri düzenini etkilediğini kabul etmesine rağmen, feshin haklı değil geçerli nedenle yapıldığı yönünde karar verdiği de olmuştur ${ }^{151}$.

İş sözleşmesinin tarafi işçi olduğundan, madde uyarınca feshe sebep olan işçinin sataşması veya sarhoşluğudur; ama doktrinde işçinin yakını tarafindan gerçekleştirilen sataşmanın da somut olayın özelliğine göre bu alt bend kapsamında değerlendirilebileceği belirtilmektedir ${ }^{152}$. Doktrinde işçinin

\footnotetext{
146 Bir işçinin başka bir işçiye yumruk atması İşK m. 25/II-d bendi kapsamında haklı neden olarak kabul edilmiştir, Y. 22. HD.24.01.2013, 2012/10688 E., 2013/743 K. (www.kazanci.com, E.T.: 15.09.2020) .

147 Y. 9. HD., 7.4.2016, 2014/36381 E., 2016/8731 K. (www.kazanci.com, E.T.: 25.06.2020).

148 Y. 22. HD., 17.1.2012, 2011/5013 E., 2012/122 K.; Y. 22. HD., 24.3.2015, 2015/7794 E., 2015/11301 K., (www.kazanci.com, E.T.: 25.06.2020).

149 Y. 22. HD., 21.1.2014, 2013/2242 E., 2014/523 K. (www.kararara.com, E.T.: 28.09.2020).

150 Y. 9. HD., 7.4.2016, 2014/36381 E., 2016/8731 K., (www.kazanci.com, E.T.: 25.06.2020).

151 “...cinsel taciz boyutuna ulaşmamakla birlikte sataşma niteliğinde olup olayın işyerine yansıdiğl ve iş akışının bozulduğu sabit olduğundan somut olayda haklı bir fesih nedeni bulunmasa bile fesih için geçerli bir nedenin bulunduğunun kabulü gerekmektedir...", Y. 7. HD., 10.3.2016, 2015/43589 E., 2016/6048 K., (www.kazanci.com, E.T.: 25.06.2020).
}

152 Süzek, s. 672; Savaş, s. 85; Öktem Songu, Sataşma, s. 131; Arslan Durmuş, s. 80. 
bir yakınının eyleminin işçi tarafından desteklendiği takdirde işverene haklı nedenle fesih yetkisi verebileceği kabul edilmiştir ${ }^{153}$. Aslında işçi yakınlarının eylemlerini kapsama alacak şekilde geniş bir yorum, "işçi lehine yorum ilkesi”"ne aykırılık teşkil eder. Ayrıca işçinin kendisinin gerçekleştirmediği bir eylem yüzünden işini kaybetmesi ve bu yüzden kıdem tazminatı ile işsizlik ödeneğinden mahrum kalacak olması ceza sorumluluğunun şahsiliği ilkesiyle de bağdaşmayacaktır. Bu sebeple işçinin yakınlarının eyleminin geçerli neden olarak değerlendirmenin daha uygun olabileceği düşüncesindeyiz. Ancak genel bir kabul mümkün değildir. İşçinin yakınının sataşmasının haklı neden mi geçerli neden mi olduğuna ilişkin tespiti her somut olayda tekrar ele almak gerekir ${ }^{154}$. Önemli sonuçları olan haklı nedene, işçinin kendi iradesi dişında bir fiilin sebep olacağ kabul edilemez; ancak yakınının davranışına bizzat işçi sebep olduysa, onu kışkırtmış ya da azmettirmişse haklı nedenle fesih gündeme gelebilir ${ }^{155}$.

Sataşılan kişi bakımından ise aile üyelerinin ne ifade ettiğini değerlendirirsek, doktrinde bu tabirin işverenin eşi ve çocukları, kendisiyle birlikte otursun veya oturmasın yakın akrabalarını kapsadığı belirtilir. Aile üyeleri kapsamını çok dar tutmak uygun görülmediği gibi çok geniş tutmak da uygun değildir. Katıldığımız görüşe göre hısımlığın derecesi değil, kişiler arasında ciddi ve kuvvetli bağ olup olmadığını değerlendirmek yerinde olacaktır $^{156}$.

İşçinin sataşması bakımından irdelenmesi gereken bir diğer husus ise, bu sataşmanın iş süreleri ile sınırlı olup olmayacağıdır. Kanunda sataşmanın yeri ve zamanına ilişkin herhangi bir açıklama yoktur. Bu sebeple doktrinde de kabul edildiği üzere somut olayın özelliğine göre iş süresi ve işyeri dışındaki sataşmalar da haklı neden teşkil edebilir ${ }^{157}$. Çalışma saatleri ve

153 Savaş, s. 85; Odaman, Ahlak ve İyiniyet Kuralları ve Benzerleri, s. 130.

154 Örneğin, Yargıtay'ın bir kararında "davacının polis memuru olan kocasının Bankaya gelerek ...'1 personelin önünde dövüp küfür ettiği, olayın bu şekilde meydana gelmesinde davacının rolü ve etkisi bulunduğu"nu belirterek, her ne kadar sataşmayı işçinin eşi yapmış olsa da onu azmettiren kendisi olduğundan bu olay bakımından haklı neden nitelendirmesinin yerinde olduğu kabul etmiş, [Y. HGK., 19.10.1983, 1981/9-618 E., 1983/981K., (E.T.:04.04.2020, www.kazanci.com)]; işçinin eşinin işveren vekiline küfür etmek suretiyle sataştığı bir başka davada ise feshin geçerli olacağı ama haklı neden teşkil etmeyeceği sonucuna varmıştır, [Y. 9. HD, 13.10.1998, 1998/11465E., 1998/ 14315K., (E.T.:04.04.2020, www.kazanci.com)].

155 Odaman, Ahlak ve İyiniyet Kuralları ve Benzerleri, s. 130; Arslan Durmuş, s. 80.

156 Öktem Songu, Sataşma, s. 124, 142. Bu doğrultuda işverenin üye olduğu bir siyasi partiye veya sendikaya ya da müşterisine sataşma bu bent kapsamında değerlendirilmemelidir, (Arslan Durmuş, s. 77).

157 Eyrenci/Taşkent/ Ulucan, s. 251; Süzek, s. 672; Ergin, ss. 76, 86; Öktem Songu, Sataşma, ss. 123, 142. 
işyeri dışındaki sataşmalarda, söz veya davranışın işyerinin düzeni bakımından olumsuz bir sonuç doğurup doğurmadığına göre haklı neden teşkil edip etmeyeceğinin belirlenmesi uygun görülmüştür ${ }^{158}$. Bu bakımdan doktrinde işverene ve aile üyelerine yapılan sataşma ile işverenin işçisine yapılan sataşmanın aynı şekilde değerlendirilmemesi gerektiği de ileri sürülmüştür. Örneğin, işyeri dışında bir sataşma varsa ve eğer bu işverene ya da ailesine karşı ise haklı neden teşkil edeceği kuşkusuzdur; ancak, eylem işverenin bir diğer işçisine karşı ise bunun doğrudan haklı neden olarak değerlendirilmesi uygun değildir. İşyeri dışında, işçinin işverenin bir başka işçisine sataşması işyerine ilişkinse ya da işyerine ilişkin olmasa da, bu durum işyeri ve çalışma düzenini kötü etkileyecekse davranış haklı neden olarak kabul edilmelidir ${ }^{159}$. Sonuç olarak farklı işyerlerinde çalışan işçilerin işyeri dışında işle ilgili olmayan ve çalışma düzenini aksatmayacak sataşmaları tamamen kişilerin özel hayatına dair olacağından, bunların haklı neden kabul edilmesi uygun görülmemiştir ${ }^{160}$. İşyeri dışında olduğu gibi işyerinde işveren ve ailesine karşı olan sataşmaların da haklı neden teşkil edeceği şüphesizdir; ancak, işçinin bir başka işçiye karşı işyerinde sataşmasını doğrudan haklı neden saymanın mümkün olup olmadığı sorusunu yanıtlamak gerekir. Bu konuda farklı görüşler mevcuttur. Bir görüşe göre işyerinde gerçekleşen sataşma işyeri düzenine etkisine bakılmaksızın mutlak şekilde haklı neden olarak kabul edilmelidir. Fakat mutlak haklı neden olması işverenin feshe başvurma zorunluluğunu getirmeyecektir ${ }^{161}$. Ancak bir başka görüşe göre işverenin işçiyi gözetme borcu olduğundan sataşan işçinin iş sözleşmesini feshetmesi gerektiği belirtilmiştir ${ }^{162}$.

Önemli olan bir başka durum ise, sataşmaya sebebiyet veren kişi, buna maruz kalan işveren, işverenin ailesi ya da bir başka işçisiyse, sataşmanın haklı neden olarak değerlendirilemeyeceğinin doktrinde kabul edilmesidir ${ }^{163}$. İzmir Bölge Adliye Mahkemesi de bu yönde karar vermiştir ${ }^{164}$. Yargıtay'ın bir karşı oy yazısında da kişinin onur, şeref ve haysiyetine, kişilik haklarına,

158 Süzek, s. 672; Mollamahmutoğlu/Astarlı/Baysal, s. 239; Eyrenci/Taşkent/Ulucan, s. 251; Ergin, s. 76; Öktem Songu, Sataşma, s. 123,142, Arslan Durmuş, s. 77.

159 Tunçomağ/Centel, s. 225; Demir, s. 409-410; Senyen Kaplan, İş Hukuku, s. 284; Mollamahmutoğlu/Astarlı/Baysal, s. 239.

160 Mollamahmutoğlu/Astarlı/Baysal, s. 239; Öktem Songu, Sataşma, s. 130.

161 İşverenin işçisine karşı işlenen bir suç varsa bildirme yükümlülüğü doğacağından haklı nedenle fesih adeta bir zorunluluk haline gelecektir bkz. II. B. İşverenin Suçu Bildirme Yükümlülüğü.

162 Atabek, Reşat: İş Akdinin Feshi, Arkadaş Basımevi, İstanbul, 1938, s. 138.

163 Mollamahmutoğlu/Astarlı/Baysal, s. 239; Öktem Songu, Sataşma, s. 139.

164 İzmir, BAM, 3. HD., 20.11.2018, 2018/632 E., 2018/1683K., (www.kazanci.com, E.T.: 14.09.2020). 
fiziksel bütünlügüne veya değerlerine yönelik bir saldırı karşısında sessiz kalınmasını beklemenin hukuka aykırılık olacağı belirtilmiştir ${ }^{165}$. Fakat işçinin karşılık olarak gerçekleştirdiği sataşma, tahriki aşan ölçüdeyse, sataşanın iş sözleşmesi haklı nedenle feshedilebilecektir ${ }^{166}$.

Sataşma, ceza hukukumuzda kullanılan bir terim değildir. Borçlar hukukumuzda da sataşma terimine rastlanmaz. $\mathrm{Bu}$ sebeple sataşma yerine "kişilik haklarına saldırı teşkil eden her türlü söz ve davranış" ifadesinin kullanılmasının daha uygun olacağı düşünülür ${ }^{167}$. Sataşma kavramı, tek başına TCK' da bir suç olarak düzenlenmemiştir; ama buna rağmen bu haklı nedeni de çalışmamız kapsamında incelemekteyiz. Çünkü sataşma suçu bulunmasa da, sataşma olayını meydana getirecek söz ve davranışlar kendi başlarına çeşitli suçlara karşılık gelebilecek niteliktedir. Yukarıda sataşmanın ne anlama gelebileceğiyle ilgili açıklamalarımız doğrultusunda, ceza hukuku bakımından TCK m. 106'daki tehdit, TCK m. 107'deki şantaj, TCK m. $108^{\prime}$ 'deki cebir, TCK m. $125^{\prime}$ 'deki hakaret ${ }^{168}$ ve özellikle de TCK m. 86 ve devamındaki yaralama suçlarının işçinin sataşmasında ortaya çıkabileceğini söyleyebiliriz.

İşK. m. 25/II-d alt bendinde belirtilen diğer haklı neden ise alkol ve uyuşturucu madde kullanımıdır. Bu haklı nedenin gerçekleşmesi için işçinin alkolik ya da uyuşturucu bağımlısı olması gerekmez. Kanunda belirtilen koşulların bulunması fesih için yeterlidir ${ }^{169}$.

Alkol, işyerinde kullanılmadığı, işçi işyerine sarhoş gelmediği ve işini normal şekilde yürütmesine engel olmadığı sürece fesih nedeni olarak değerlendirilemeyecektir ${ }^{170}$. Ancak Yargıtay'ın da kabul ettiği üzere işçinin

165 Y. 22. HD., 21.1.2014, 2013/2242 E., 2014/523 K., (www.kararara.com E.T.: 25.06.2020).

166 Öktem Songu, Sataşma, s. 139.142. Bkz. "Diğer taraftan feshe konu olayda tahrik unsuru bulunsa bile davacının sözlü bir sataşmadan ibaret olan olayda abartılı ve orantısız bir tepki gösterdiği, hedef dahi gözetmeden bıçakla yaralama olayını gerçekleştirdiği açıktır...", Bkz. Y. HGK., 04.04.2018, 2015/3165 E., 2018/676 K., www.emsal.co, (E.T.:14.04.2020).

167 Ergin, ss. 75, 85, Öktem Songu, Sataşma, s. 115.

168 Ayrıca bkz. III. A. 2. İşçinin Şeref ve Namusuna Dokunacak Söz ve Davranışları

169 Eyrenci/Taşkent/Ulucan, s. 251; Süzek, s. 673.

170 Tunçomağ/Centel, s. 225; Süzek, s. 673; Güzel, s.259-260; Mollamahmutoğlu/ Astarlı/Baysal, s. 239; Narmanlıoğlu, s. 444; Odaman, Ahlak ve İyiniyet Kuralları ve Benzerleri, s. 131; Caniklioğlu, Nurşen: "İş İlişkisinin Sona Ermesi ve Kıdem Tazminatı", Yargıtay'ın İş Hukuku ve Sosyal Güvenlik Hukuku Kararlarının Değerlendirilmesi 2017, Onikilevha Yayıncılık, İstanbul, Kasım 2019, ss. 185-368, s. 320-321, Savaş, s. 93. Bkz. Y. HGK., 9.6.2004, 2004/9-352 E., 2004/352 K., Y. 22. HD., 20.11.2017, 2015/19348 E., 2017/25150 K. (www.kazanci.com, E.T.:16.06.2020). 
alkolü işyerinde alması durumunda alkolün miktarı ve işçi üzerindeki etkisi ne olursa olsun işverene haklı nedenle fesih imkânı verecektir ${ }^{171}$.

$\mathrm{Bu}$ alt bent kapsamında işyerini, İşK. m. 2/II'deki tanıma göre değerlendirmek gerekir ${ }^{172}$. Bu doğrultuda "isyerinde ürettiği mal veya hizmet ile nitelik yönünden bağlllı̆̆ bulunan ve ayn yönetim altında örgütlenen tüm yerler (işyerine bağll yerler) in yanı sira dinlenme, çocuk emzirme, yemek, uyku, ylkanma, muayene ve bakım, beden ve meslekî eğitim ve avlu gibi diğer eklentiler ve araçlar" bakımından da m. 25/II-d alt bendi esas alınacaktır. Ancak işçi gazinosu ya da lokali gibi işyeri eklentisi sayılan yerlerde işverence içki içilmesine izin verilmişse, o zaman haklı neden söz konusu olmayacaktır ${ }^{173}$. İşinin gereği alkollü içki içmek zorunda kalan işçilerde de kuşkusuz bu durum iş sözleşmesinin feshi bakımından haklı neden kapsamında değerlendirilmemektedir (İşSGK m. 28/III).

Alkol kullanılması esas olarak ceza hukuku anlamında bir suç teşkil etmez. Ancak bu işçinin nerede çalıştığına göre değiş̧ebilir. Örneğin, işçinin görevi, "kara, deniz, hava veya demiryolu ulaşım araçlarını kullanmak" ise, burada TCK m. 179'daki "trafik güvenliğini tehlikeye sokma" suçu oluşabilecektir. Çünkü TCK m. 179//III uyarınca alkol veya uyuşturucu madde etkisiyle emniyetli bir şekilde araç kullanamayacak halde olmasına rağmen bunu kullanan kişi üç aydan iki yıla kadar hapis cezası ile cezalandırılır. Ya da işçi bir infaz kurumunda veya tutukevinde çalışıyorsa ve çalıştığ alkol tüketirse, TCK m. 297 "İnfaz kurumuna veya tutukevine yasak eşya sokmak" suçundan yargılanacaktır.

Uyuşturucu bakımından ise madde metninden anlaşıldığ üzere sadece kullanılmış olması fesih için yeterlidir. İster işyerinde ister işyeri dışında

Ancak manevi amaçlı işletme (Tendenzbetrieb) kavramından yola çıkılarak alkol kullandığına ilişkin işvereni yanıltması durumunda iş sözleşmesinin haklı nedenle feshedebilmesi ya da somut olaya göre aynı mantıkla alkol kullanımı sebebiyle geçerli nedenle feshe başvurulabilmesi mümkün olup olmayacağı tartışılabilir. Manevi amaçlı işletme kavramı için bkz. IV. A. 1. İşçinin İşvereni Yanıltması

171 Süzek, s. 673; Mollamahmutoğlu/Astarlı/Baysal, s. 239; Narmanlıoğlu, s. 445; Arslan Durmuş, s. 82.

172 İşçinin görevine göre işyeri kavramı çok geniş bir nitelik kazanabilmektedir. Bu doğrultuda Yargitay'ın, müşterinin işyerinde tüketilen alkole dayanarak iş sözleşmesini haklı nedenle feshini hukuka uygun bulduğu kararı için bkz. Y. 22. HD., 20.12.2017, 2017/ 44370 E., 2017/30242 K., (www.kazanci.com, E.T.:17.09.2020). Karara konu somut olayda müşterinin işyerinde alkol tüketiminin haklı değil geçerli neden sayılmasının uygun olacağı görüşü için bkz. Caniklioğlu, s. 323.

173 İş Sağlı̆̆ı ve Güvenliği Kanunu (İşSGK - R.G. Tarih: 30.6.2012 R.G. Sayı : 28339) m. 28/II: "İ̧̧veren; işyeri eklentilerinden sayılan kısımlarda, ne gibi hallerde, hangi zamanda ve hangi şartlarla alkollü içki içilebileceğini belirleme yetkisine sahiptir". 
kullanılsın, eğer iş̧̧inin uyuşturucu madde kullandığı tespit ediliyorsa, kendisinde herhangi bir sarhoşluk etkisi yaratmasa dahi işveren haklı nedenle sözleşmeyi derhal feshedebilecektir ${ }^{174}$. Ayrıca maddede belirtilmemişse de bulundurmanın da haklı nedenle fesih hakk1 sağlayacağ kabul edilmiştir ${ }^{175}$. Zaten uyuşturucu bulundurma m. 25 II-e (işçinin doğruluk ve bağlilığa uymayan davranışları) veya II-f (işçinin iş yerinde suç işlemesi) kapsamında da haklı neden olarak kabul edilebilecektir.

Uyuşturucu kullanma ve kullanma için bulundurma doğrudan TCK m. 191 'de suç olarak düzenlenmiştir. Bunun yanı sıra, işçinin nerede çalıştığına göre, alkol kullanımında ele alınan TCK m. 179'daki "trafik güvenliğini tehlikeye sokma" ve TCK m. 297'deki "İnfaz kurumuna veya tutukevine yasak eşya sokmak" suçları uyuşturucu bakımından da gündeme gelebilecektir.

Ancak tekrar tekrar belirttiğimiz üzere davranışlar suç teşkil edebilirlerse de, haklı neden sayılmaları için bu zorunlu değildir ve ortada suç olsa da ceza mahkûmiyeti kararı aranmayacaktır ${ }^{176}$.

\section{5. İşçinin Doğruluk ve Bağlılığa Uymayan Davranışları}

İşçinin, işverenin güvenini kötüye kullanmak, hırsılılı yapmak, işverenin meslek sırlarını ortaya atmak gibi doğruluk ve bağl1lı̆a uymayan davranışlarda bulunması durumunda İşK. m. 25/II-e alt bendi uyarınca işverenin haklı nedenle fesih hakkı olacaktır. Burada "doğruluk ve bağl11ı̆a uymayan davranışlar"'ın haklı nedenle feshe olanak sağlayacağı belirtilmiş ancak soyut kavramın tanımı yapılmayıp örnekseyici sayım yolu seçilmiştir.

Doğruluk ve bağlılığa uygun davranışları, işçinin sadakat borcunun gereği olan davranışlar şeklinde nitelendirmek mümkündür ${ }^{177}$. Ayrıca bu davranışların doğruluğa ve bağlılığa aykırılık teşkil etmesi yeterlidir. Haklı nedenle fesih için bu davranış sebebiyle işverenin az ya da çok bir zarar görmesi veya işçinin maddi bir menfaat elde etmesi şartı aranmamaktadır ${ }^{178}$.

\footnotetext{
174 Mollamahmutoğlu/Astarlı/Baysal, s. 239.

175 Odaman, Ahlak ve İyiniyet Kuralları ve Benzerleri, s. 133; Arslan Durmuş, s. 83.

176 Tunçomăg/Centel, s. 225; Mollamahmutoğlu/Astarlı/Baysal, s. 239, Ergin, s. 75; Öktem Songu, Sataşma, s. 121. Bkz. I. Haklı Nedenle Fesihlerde Ceza Mahkemesi Kararı Gerekliliği ve Ceza Yargılamasının İş Mahkemesi Kararlarına Etkisi

177 Mollamahmutoğlu/Astarlı/Baysal, s. 240-241; Senyen Kaplan, s. 287-286; Arslan Durmuş, s. 86. Bkz. Y. 9. HD. 04.04.2000, 2000/2465 E., 2000/4716 K..; Y. 9. HD., 4.7.2019, 2017/11351 E., 2019/15019 K., (www.kazanci.com, E.T.: 16.06.2020).

178 Mollamahmutoğlu/Astarlı/Baysal, s. 241; Odaman, Serkan: "İş İlişkisinin Sona Ermesi ve Kıdem Tazminatı", Yargıtay'ın İş Hukuku ve Sosyal Güvenlik Hukuku Kararlarının Değerlendirilmesi 2011, Kamu-İş, Ankara, Kasım 2013, ss. 131-234, s.
} 
Maddede sayılan örnekler dışında, Yargıtay kararlarında ${ }^{179}$ da görüldüğü üzere bu haklı neden kapsamına pek çok davranış girebilir; "bankacılık ilkelerine aykırı şekilde 3. kişiler lehine bankanın riske sokulması", "işçinin rahatsızlığı olmamasına rağmen rapor alması", "işyerinden çıkarken yapılan denetimde işçinin üzerinde işyerine ait malzemeler bulunması", "zimmete para geçirilmesi", "imza taklit edip vizite kâğıdı düzenlenmesi", "raporluyken bir işçinin, rakip olabilecek bir başka işyerinde çalışması", "müşteriye ait aracın yağını şirket deposundan değiştirilmesine rağmen bunun iş emrine yazılmaması", "kaçak elektrik kullanımı", "teşvik ödülü için işçinin müşteri talebi olmadan satışlar yapması ve daha sonra bunların büyük çoğunluğunun iade edilmesi” vb. durumlar bu bent kapsamında haklı fesih nedeni olarak kabul edilmiştir ${ }^{180}$.

Örneklerin çeşitliliğinden anlaşılacağı üzere hangi davranışların doğruluk ve bağlılığa aykırılık teşkil edeceğini önceden saymak mümkün değil$\operatorname{dir}^{181}$. Burada somut olaya göre bir değerlendirme yapılacak ve davranışın güvenini sarsıcı nitelik taşıyıp taşımadığına bakılacaktır. Güvenin sarsılıp sarsılmadığının tespitinde de işçinin görevi, işyeri ve işyerindeki pozisyonu, iş yaşamının gerekleri, ilgili çalışma alanındaki gelenekler gibi objektif kriterler dikkate alınacaktır ${ }^{182}$.

Doğruluk ve bağl1lığa uymayan davranışların çeşitliliği ve İş Kanunu'ndaki örnekseyici sayımı sebebiyle bu davranışların TCK anlamında çok çeşitli suçların kapsamına girmesi mümkündür. Öncelikle maddedeki örnekler, TCK m. 155 - Güveni kötüye kullanma, TCK m. 141 vd.- Hırsılılı, TCK m. 239 - Ticarî sır, bankacılık sırrı veya müşteri sırrı niteliğindeki bilgi veya belgelerin açıklanması suçlarına karşılık gelmektedir. Yukarıda yer

168; Alp, Değerlendirme, s. 189; Arslan Durmuş, s. 86. Bkz. Y. 9. HD. 04.04.2000, 2000/2465 E., 2000/4716 K.,; Y. 9. HD. 06.06.2011, 2009/16814 E., 2011/16521 K., (www.kazanci.com, E.T.: 15.09.2020)

Bkz. Y. 22. HD. 11.01.2016, 2014/26120 E. , 2016/185 K.; Y. 9. HD. 08.05.1996, 1995/ 35973 E., 1996/9834K. ;Y. 9. HD. 09.07.1996, 1996/7565 E., 1996/15521 K.; Y. 7. HD. 28.05.2013, 2013/4847 E. , 2013/9954 K.; Y. 22. HD. 26.01.2017, 2017/504 E., 2017/ 1051 K.; Y. 9. HD. 07.10.2019, 2017/12515 E., 2019/17417 K. (www.kazanci.com, E.T.:16.06.2020).

180 Süzek, s. 674. Aslında örneklerden bazıları sadece e alt bendi değil f alt bendi kapsamında da iş sözleşmesinin sona ermesine sebep olabilir. Çünkü eğer işçi ceza yargılaması sonucu bir hüküm giydiyse ve maddedeki diğer şartlar da sağlanmışsa, söz konusu durumun İşK. m. 25/II- f alt bendi kapsamında haklı nedenle fesih olarak değerlendirilmesi mümkün olacaktır. Ayrıca bkz. III. A. 6. İşçinin İş Yerinde Suç İşlemesi.

$181 \mathrm{Bu}$ alt bent kapsamında verdiklerimizden başka örnekler ve Yargıtay kararları için bkz. Arslan Durmuş, s. 88-95.

182 Mollamahmutoğlu/Astarlı/Baysal, s. 241. 
verdiğimiz Yargıtay kararlarına yansımış davranış örnekleri doğrultusunda da zimmet ${ }^{183}$ (Bankacillk Kanunu ${ }^{184}$ m. 160), resmi belgede sahtecilik (TCK m. 204), resmi belgeyi bozma (TCK m. 205), resmi belgenin düzenlenmesinde yalan beyan (TCK m. 206), özel belgede sahtecilik (TCK m. 207), özel belgeyi bozmak, yok etmek veya gizlemek (TCK m. 208), dolandırıcılık (TCK m. 157) gibi suçların oluşmasının söz konusu olabileceği görülmektedir $^{185}$.

İşçinin işvereni yaralaması ya da başka bir işçisini öldürmesi de doğruluk ve bağl1lığa uymayan davranışlar kapsamında haklı neden olarak düşünülebilir. Ama yaralama genelde Yargıtay kararlarında aşağıda inceleyeceğimiz üzere sataşma alt bendi kapsamında karşımıza çıkmaktadır ${ }^{186}$.

Aslında eylem bir suç niteliğindeyse yani işçi bir suç işlediyse, hangi haklı neden kapsamına girebileceğinin önemi olmaksızın $\mathrm{f}$ alt bendi ${ }^{187}$ uyarınca haklı nedene başvurulabilecektir. Ancak $f$ alt bendini incelerken görüleceği üzere, işçinin suçtan bir mahkûmiyet alana kadar veya mahkûmiyet alındığı ancak kararın henüz kesinleşmediği veya suçun ertelendiği ya da bir şekilde işçinin beraat ettiği ${ }^{188}$ durumlarda, işçinin davranışı, doğruluğa ve bağlılığa uymayan davranışlar kapsamında ya da incelediğimiz sataşmaya ilişkin d alt bendi kapsamında ${ }^{189}$ haklı neden olarak değerlendirilip iş sözleşmesi feshedilebilecektir.

Tüm haklı nedenlerde olduğu gibi, bu nedende de davranışın suç niteliği taşıması veya bir suç teşkil ediyorsa ceza yargılamasıyla tespit edilmiş olması gerekmemektedir ${ }^{190}$.

183 Zimmet (TCK m. 247), normalde kamu görevlileri açısından mümkün olduğundan işçilerde söz konusu olmayacak gibi düşünülebilirse de, özel bankalardaki çalışan işçiler Bankacılık Kanunu'nu uyarınca zimmet suçu işleyebilmektedirler.

1845411 sayılı Bankac1lık Kanunu - RG. Tarihi: 01.11.2005 RG. Sayıs1: 25983.

185 Ayrica bkz. Y. HGK, 15.11.2018, 2015/22-2715 E., 2018/1720 K.; Y. 9. HD., 3.10.2018, 2018/5910 E., 2018/17399 K.; Y. 9. HD., 11.9.2003, 2003/13575 E., 2003/ 14238 K.; Y. HGK, 17.4.2002, 2002/9-292 E., 2002/312 K.; Y. 9. HD., 24.4.2001, 2001/ 3960 E., 2001/6884 K (www.kazanci.com, E.T.: 23.09.2020).

Bkz. Y. HGK., 04.04.2018, 2015/3165 E., 2018/676 K., www.emsal.co, (E.T.: 14.04.2020).

187 Bkz. III. A. 6. İşçinin İş Yerinde Suç İşlemesi

188 Eğer maddi olgu tespiti yoksa -işçinin eylemi gerçekleştirmediği ispat edilemediyse-

189 Bkz. III. A. 4. a. İşçinin Sataşması

190 Çelik/Caniklioğlu/Canbolat, s. 296; Narmanlığlu, s. 448; Arslan Durmuş, s. 87. Bkz. I. Haklı Nedenle Fesihlerde Ceza Mahkemesi Kararı Gerekliliği ve Ceza Yargılamasının İş Mahkemesi Kararlarına Etkisi. 


\section{6. İşçinin İş Yerinde Suç İşlemesi}

İşçinin, işyerinde yedi günden fazla hapisle cezalandırılan ve cezası ertelenmeyen bir suç işlemesi durumunda işveren İşK. m. 25/II-f alt bendi uyarınca iş sözleşmesini haklı nedenle feshedebilir.

Haklı nedenin oluşması için ilk şart suçun işyerinde işlenmiş olmasıdır. Bu sebeple diğer şartları sağlasa da, işçi işyeri dışında bir suç işlediyse bu alt bent kapsamında değerlendirilemez. Ama bu ortada bir haklı neden olmadığ 1 anlamına gelmeyecektir. Somut olay, İşK m. 25/II'deki “incelediğimiz diğer suç teşkil edebilecek haklı nedenler" (Örneğin, işçinin bir başka işçiye cinsel tacizde bulunması durumunda işyerinde işlenmiş olma şartı aranmayacaktır) ya da İşK m. 25/III'deki "zorlayıcı sebepler" (Hükme göre iş̧̧iyi işyerinde bir haftadan fazla süre ile çalışmaktan alıkoyan zorlayıcı bir sebebin ortaya çıması durumunda haklı nedenle fesih mümkündür. Örneğin, işçinin işyeri dışında işlediği bir suçtan dolayı yedi günden fazla hapis cezası alması durumunda zorlayıcı neden ortaya çıkmış olacaktır) kapsamında değerlendirilebilecektir. Somut olayın bu iki seçeneğin kapsamına da girebilmesi mümkün olabilir. Bu durumda haklı nedenle feshin "Ahlak ve iyi niyet kurallarına uymayan haller ve benzerleri" mi yoksa "Zorlayıcı Sebepler" bendi uyarınca mı gerçekleştirileceği önem arz edecektir. İşçinin menfaati düşünüldüğünde III. bent kapsamında haklı nedenle feshin uygulanması gerektiği kabul edilmeliyse de, aslında işverenin hangi nedene başvuracağı onun seçimine kalmıştır. İşK. m. 25/III uyarınca işçinin iş sözleşmesini feshetmek işçinin lehinedir. Bu lehe etki doğrudan ve dolaylı olabilecektir. Doğrudan etki, işçinin şartlarını taşıyorsa kıdem tazminatı alabilmesi, dolaylı etki ise yeni iş başvurularında II. bent nedeniyle işten çıkarılmış olmasının yaratacağı negatif izlenimin (işçiye karşı önyargının) bir ölçüde önüne geçilebilmesidir ${ }^{191}$. Ama suç işyerinde işlenmediyse ve işyeri dışında işlenmesine rağmen haklı nedene yol açabilecek bir suç niteliği taşımıyorsa, kuşkusuz işverenin seçim hakkı olmayacak zorlayıcı sebep nedeniyle iş sözleşmesini feshedebilecektir. İnşaatta çalışan bir duvar ustasının işyeri sınırları dışında, şahsi aracıyla yaptığı trafik kazası sebebiyle alacağı hapis cezası buna örnek gösterilebilir.

Sataşma ve sarhoşluğa ilişkin haklı nedende olduğu gibi burada da işyerini İşK. m. 2/II uyarınca geniş düşünmek gerekir. Örneğin, işçi işyerine ait bir araçla yaptığı kaza sebebiyle yedi günü aşan bir hapis cezası almış ve

191 Elbette işveren haklı nedene konu olayın ne olduğunu çeşitli yollarla öğrenebilir. Ama işe alım safhaları düşünüldüğünde (daha başvuru evrakları verilmeden internet üzerindeki başvurularda yapılan elemeler vs.) bu dolaylı etkinin de önemli olacağı kanaatindeyiz. 
bu ceza ertelenmemişse iş sözleşmesi İşK. m. 25/II-f uyarınca feshedilebilir $^{192}$.

Kanunda "cezalandırılan ve cezası ertelenmeyen" ifadesi kullanılmıştır. Bu sebeple eğer davranış başka bir madde hükmü kapsamına sokulamıyorsa, iş sözleşmesinin feshedilebilmesi için kovuşturma bitmeli ve mahkûmiyet kararı kesinleşmelidir ${ }^{193}$. Kesinleşmemiş yedi günü aşan bir hapis cezası varsa ne olacağı sorusunu yanıtlamak da gerekir. Kanaatimizce burada işverenin İşK. m. 25/IV ${ }^{194}$ deki haklı nedene başvurabilmesi mümkün olacaktır. Ceza ve Güvenlik Tedbirlerinin İnfazı Hakkında Kanun m. 4'e göre mahkûmiyet hükümleri kesinleşmedikçe infaz olunamaz; ama uygulamada mahkûmiyetin kesinleşmesine kadarki süreçte, Adalet Bakanlığı Ceza ve Tevkifevleri Genel Müdürlüğü 22.01.2007 tarih ve 45/1 sayılı Genelgesi’nde yer alan ifadeyle "hükümözlü", Yargitay ${ }^{195}$, a göre ise "hükmen" sanık tutuklanmaktadır $^{196}$. Sanık, tutuklu olduğu için de işveren, gözaltı ve tutukluluk hallerine ilişkin düzenleme (İşK m. 25/IV) uyarınca iş sözleşmesini haklı nedenle feshedebilecektir.

İşK m. 25/II-f açısından irdelenmesi gereken bir başka husus, mahkûm olunan hapis cezasının yedi günden fazla olması gerekliliğidir. Burada neden yedi günlük süre öngörüldügüne bakmak gerekir. Öncelikle Türk Ceza Kanunu'nda 7 günlük bir alt sınırı olan hapis cezası yoktur. Bunun sonucunda yedi günden daha az bir hapis cezası da zaten mümkün olmayacaktır ${ }^{197}$. TCK kapsamındaki hapis cezalarında bir yanıt bulamadığımız bu alt sınır, disiplin ve tazyik hapislerinin ertelenememesi ve sürelerin kısalığı düşünüldüğünde mantıklı gelebilecek olsa da, İşK. m. 25/II-f'de 7 günden fazla hapisle cezalandırılan bir suçun işlenmesinden söz edildiği için bu hüküm kapsamına disiplin ${ }^{198}$ ve tazyik hapisleri giremeyecektir. Çünkü disiplin ve tazyik

192 Eyrenci/Taşkent/Ulucan, s. 252; Süzek, s. 708; Demir, s. 412; Mollamahmutoğlu/ Astarlı/Baysal, s. 241.

193 Tunçomağ/Centel, s. 227; Mollamahmutoğlu/Astarlı/Baysal, s. 241; Narmanlıŏglu, s. 450-451; Senyen Kaplan, İş Hukuku, s. 286.

194 İşK. m. 25/IV: Issçinin gözaltına alınması veya tutuklanması halinde devamsızlı̆̆ın 17.maddedeki bildirim süresini aşması.

195 Bkz. Y. CGK. 12.4.2011, 2011/1-51 E., 2011/42 K., (www.kazanci.com, E.T.: 25.06.2020)

196 Hükmen tutuklulukla ilgili ayrıntılı bilgi için bkz. Özbek/Doğan/Bacaksız, Ceza Muhakemesi, s. 293.

1977 günden fazla ve ertelenmemiş olmanın birlikte düzenlenmesi ise problemli bir durum değildir. Çünkü hapis cezası 1 ay bile olmasa, bu ceza her durumda ertelenemez veya adli para cezasına çevrilemez. Çünkü bu iki seçeneğin de şartlarının sağlanmamış olması mümkündür.

198 CMK m. 2/I-1: "Disiplin hapsi: Kısmî bir düzeni korumak amactyla yaptırım altına alınmış olan fiil dolayısıyla verilen, seçenek yaptırımlara çevrilemeyen, önödeme uygu- 
hapislerinde cezalandırılan bir suç bulunmamaktadır. Ancak bu, bir işçiye disiplin ya da tazyik hapsi uygulanması durumunda haklı nedenle işçinin iş sözleşmesinin feshedilemeyeceği anlamına gelmez. Disiplin ve tazyik hapisleri $\mathrm{f}$ altı bendi kapsamında değerlendirilemese de; başka haklı neden kapsamında iş sözleşmesinin feshine sebep olabilirler. Burada cevapland1rılması gereken disiplin ve tazyik hapisleri sebebiyle haklı nedenle sözleşmeyi feshetmek isteyen işverenin, İşK. m. 25/III (zorlayıc1 sebepler)'e mi yoksa İşK. m. 25/IV (gözaltı ve tutukluluk sebebiyle devamsızlık)'e mi başvuracağıdır. İşK. m. 25/IV'e göre işçinin gözaltına alınması veya tutuklanması halinde devamsızlık, işçinin kıdemi uyarınca sahip olduğu bildirim süresini aşarsa iş sözleşmesi haklı nedenle feshedilebilecektir. İşK. m. 25/ III'de ise bir haftayı geçen zorlayıcı sebep aranmaktadır. İş m. 17/I'e göre bildirim süresinin 2 haftaya kadar çıkabileceği düşünüldüğünde İşK. m. 25/IV'ün disiplin ve tazyik hapsine uygulanacağını kabul etmek işçi lehine olacaktır. Bu doğrultuda 2 haftaya kadar bir disiplin ya da tazyik hapsi söz konusu olduğunda haklı nedene başvurabilme hakkı doğmayacağı söylenebilecektir.

Ancak İşK. m. 25/IV'de işçinin bildirim süresini aşan "gözaltı ve tutukluluk hali" düzenlenmiştir. Bu nedenin disiplin ve tazyik hapislerine dayanak olabileceğini söylemek için bu hapis türlerinin tutukluluk olarak kabul edilmesi gerekir. Doktrinde özel tutukluluk halleri sayılırken disiplin hapislerine de yer verilmiştir ${ }^{199}$. Bu sebeple disiplin hapisleri ve tazyik hapislerinin tutukluluk olarak değerlendirilmesinin yanlış olmayacağı kanaatindeyiz. Ama iki hafta ve daha fazla bir disiplin ya da tazyik hapsi varsa hangi hüküm kapsamında değerlendirilirse değerlendirilsin sonuç değişmeyecek ve iş sözleşmesi haklı nedenle sona erdirilebilecektir. Bu sebeple İşK. m. 25/III'e ya da İşKK. m. 25/IV'e dayanılması fark etmeyecektir. Buna rağmen "gözaltı ve tutukluluktan dolayı devamsızlık" nedeninin işe alımlarda işverende bir önyarg1 oluşturabileceğinden, İşK. m. 25/III (zorlayıc1 sebepler)'e dayanılmasının işçinin lehine olacağını söyleyebiliriz.

İşK. m. 25/II-f alt bendinde neden hapis cezası için 7 gün sınırı konulduğu sorusuna geri dönersek, kanaatimizce bu sınırın konmasının nedeni ceza mevzuatından kaynaklanmamıştır. Bu sınırın sebebinin İşK. m. 25/III. bendi olduğu düşüncesindeyiz. İșK. m. 25/III kapsamında, hapis cezasını bir zorlayıcı neden olarak kabul ettiğimizde, bu süre bir haftayı aşmazsa haklı nedenle fesih mümkün olmayacaktır. Sonuç olarak $f$ alt bendinde, zorlayıcı sebeplere ilişkin hükümle bir bütünlük sağlanması için "yedi günü aşan ve

lanamayan, tekerrüre esas olmayan, şartla salıverilme hükümleri uygulanamayan, ertelenemeyen ve adli sicil kayitlarına geçirilmeyen hapsi ifade eder".

Özbek/Doğan/ Bacaksı, Ceza Muhakemesi, s. 285. 
ertelenmeyen hapis cezaları" ifadesine yer verildiği kanaatindeyiz. Ancak şu an hukuk sistemimizde bir suç sebebiyle 7 günden daha az bir hapis cezasının uygulanması mümkün olmadığı için bu düzenlemenin somut bir etkisi bulunmamaktadir.

\section{7. İşçinin İş Güvenliğini Tehlikeye Düşürmesi veya İşverenin Malına Zarar Vermesi}

İşçinin kendi isteği veya savsaması yüzünden işin güvenliğini tehlikeye düşürmesi, işyerinin malı olan veya malı olmayıp da eli altında bulunan makineleri, tesisatı veya başka eşya ve maddeleri otuz günlük ücretinin tutarıyla ödeyemeyecek derecede hasara ve kayba uğratması durumunda İşK. m. 25/II-1 alt bendi uyarınca işveren iş sözleşmesini haklı nedenle feshetme hakkını kazanacaktır.

Burada iki ayrı fesih nedeni mevcuttur. Birincisi işin güvenliğinin tehlikeye düşmesi, diğeri ise işyerinde bulunan eşya ve maddelerin zarar görmesidir. İlk sebepte bir zarar aranmamış tehlikeye düşürülmesi yeterli bulunmuştur. Diğer hususta ise işçinin otuz günlük ücret tutarını aşan derecede zararın doğmuş olması gereklidir.

Her iki nedenle de işverenin fesih hakkını kullanabilmesi için bu durumların işçinin kusurlu bir davranışı ile meydana gelmesi gerekir. Bu sebeple, olayda işçinin kastı (kanundaki ifadeyle "isteği") ya da ihmali (kanundaki ifadeyle "savsaması") mevcut değilse ve tehlike veya zarar, mücbir sebep ya da kaçınılması mümkün olmayan halden doğmuşsa haklı nedenle fesih söz konusu olmayacaktır ${ }^{200}$.

İş güvenliğinin tehlikeye düşmesi bakımından zararın oluşmasının gerekmediğini zarar ihtimalinin bulunmasının yeterli olacağını belirttik. Bu sebeple burada önemli olan husus objektif olarak bir tehlikenin bulunup bulunmadığgdır ${ }^{201}$.

Otuz günlük ücret tutarını aşan zarara ilişkin olarak da zararın tazmin edilecek olmasının haklı nedenle feshi ortadan kaldırmayacağını belirtmemiz gerekir. Çünkü maddede zararın karşılanmaması sebebiyle işverene fesih hakkı verilmemiştir. Zararın meydana gelmesi işverenin iş sözleşmesini haklı nedenle feshedebilmesi için yeterlidir. Bu sebeple işçinin zararı karş1layacağını belirtmesi, dahası karşılaması feshe engel olamaz ${ }^{202}$.

200 Eyrenci/Taşkent/Ulucan, s. 254; Süzek, s. 678; Mollamahmutoğlu/Astarlı/Baysal, s. 245; Senyen Kaplan, İş Hukuku, s. 288; Arslan Durmuş, s. 126, 129.

201 Mollamahmutoğlu/Astarlı/Baysal, s. 244; Senyen Kaplan, İş Hukuku, s. 288. Bkz. 9. HD. 02.11.2004, 2004/1834 E. 2004/24692 K., www.kazanci.com, (E.T.:25.06.2020).

202 Eyrenci/Taşkent/Ulucan, s. 255; Mollamahmutoğlu/Astarlı/Baysal, s. 245; Arslan Durmuş, s. 131. 
İşK. m. 25/II-1 alt bendindeki iki ayrı neden de TCK'da düzenlenmiş çeşitli suçlara karş1lık gelebilir. Öncelikle işçinin "iş̧in güvenliğini tehlikeye düşürmesi”, görevi ve çalıştı̆̆ işyerine göre TCK m. 170 "Genel güvenliğin kasten tehlikeye sokulması", TCK m. 171 "Genel güvenliğin taksirle tehlikeye sokulması", TCK m. 172 "Radyasyon yayma", TCK m. 173 "Atom enerjisi ile patlamaya sebebiyet verme", TCK m. 174 "Tehlikeli maddelerin izinsiz olarak bulundurulması veya el değiştirmesi”, TCK m. 175 "Ak11 hastası üzerindeki bakım ve gözetim yükümlülüğünün ihlali”, TCK m. 176 "İnşaat veya yıkımla ilgili emniyet kurallarına uymama", TCK m. 177 "Hayvanın tehlike yaratabilecek şekilde serbest bırakılması", TCK m. 178 "İşaret ve engel koymama", TCK m. 179 "Trafik güvenliğini tehlikeye sokma", TCK m. 180 "Trafik güvenliğini taksirle tehlikeye sokma", TCK m. 181 "Çevrenin kasten kirletilmesi", TCK m. 182 "Çevrenin taksirle kirletilmesi", TCK m. 183 "Gürültüye neden olma", TCK m. 184 "İmar kirliliğine neden olma", TCK m. 185 "Zehirli madde katma", TCK m. 186 "Bozulmuş veya değiştirilmiş gıda veya ilaçların ticareti”" ve TCK m. 187 "Kişilerin hayatını ve sağlığını tehlikeye sokacak biçimde ilaç yapma veya satma" suçlarından birine karşıllk gelebilir.

İşçinin, otuz günlük ücretinin tutarıla ödeyemeyecek derecede işvereni hasara ve kayba uğratması durumu da TCK m. 151/203 uyarınca "mala zarar verme" ye karşılık gelecektir. Bu suçun iş hukuku ile doğrudan bağlantılı nitelikli hali ise TCK m. 152/I-e'de düzenlenmiştir. Buna göre grev veya lokavt durumlarında, işverenlerin, işçilerin, işveren veya işçi sendika / konfederasyonlarının maliki olduğu ya da kullanımındaki bina, tesis veya eşyalarda oluşan zarar "mala zarar verme suçu"nun nitelikli halidir ve bu durumda cezanın alt ve üst sınırı artmaktadır.

\section{B. İşçinin Haklı Nedenle İş̧ Sözleşmesini Feshedebilmesi Bakımından}

İşveren gibi işçiler de haklı nedenle iş sözleşmesini derhal feshedebilir. İşçinin dayanabileceği haklı nedenler ise İşK. m. 24'de düzenlenmiştir. Konumuz bakımından incelememiz gereken işçinin haklı fesih nedenleri ise işverenin feshinde olduğu gibi "ahlak ve iyi niyet kurallarına uymayan haller ve benzerleri”" bendi kapsamında ele alınmıştır ${ }^{204}$.

\footnotetext{
203 TCK m. 151/I: "başkasının taşınır veya taşınmaz malını kısmen veya tamamen yıkan, tahrip eden, yok eden, bozan, kullanilamaz hale getiren veya kirleten kişi, mağdurun şikâyeti üzerine, dört aydan üç yıla kadar hapis veya adlî para cezası ile cezalandırılacaktır".

$204 \mathrm{Bu}$ nedenlerin örnekseyici sayım olması konusundaki açıklamalar için bkz. III. A. İşverenin Haklı Nedenle İş Sözleşmesini Feshedebilmesi Bakımından
} 
İşçinin fesih nedenlerinin kanunda sayılan haklı neden kapsamında olup olmadığının tespiti, "işçinin derhal fesih yapamayıp bir bildirim süresine uyup uymayacağı", "bildirim süresine uyması gerekiyor ama uymuyorsa ihbar tazminatı ödemek zorunda kalması" ve "kıdem tazminatına hak kazanabilmesi" bakımından önemlidir.

Ancak somut olaydaki nedenin, kanunda sayılan hangi haklı neden düzenlemesi kapsamında değerlendirileceği işverendeki gibi elzem olmayacaktır. Çünkü işçi hangi haklı nedene dayanırsa dayansın, iş sözleşmesini ihbar tazminatı ödemek zorunda kalkmaksızın derhal feshedebilmekte ve bunun sonucunda k1dem tazminatı alabilmektedir.

İşK. m. 25/II'deki "ahlak ve iyi niyet kurallarına uymayan haller ve benzerleri” kapsamındaki gibi İşK. m. 24/II'de de çeşitli suçlara açıkça yer verilmiş ya da suç niteliği açıkça ifade edilmemişse de, ceza hukuku anlamında bir suça karşılık gelebilecek davranışlar haklı neden olarak kabul edilmiştir. İşçinin suçu bildirme yükümlülüğünü incelerken belirtmiş olduğumuz üzere, her ne kadar İşK. m. 24/II sınırlı sayım ilkesine tabi olmasa da işçinin zor durum yaşaması ihtimalini ortadan kaldırma amacıyla bazı eklemeler yapılabileceği kanaatindeyiz.

Aşağıda inceleyeceğimiz üzere İşK. m. 24/II kapsamındaki nedenler işverenin, işçiye veya ailesine karşı çeşitli tutum ve davranışlardır. İşçinin bu konularda zaten bir suçu bildirme yükümlülüğü yoktur. Suçu bildirme yükümlülüğü doğacağ 1 tüm hususları da örnekseyici sayıma dayanarak haklı neden kapsamına sokmak mümkün olmayabilir. İşyerindeki bir işçiyi ama özellikle işvereni ihbar ettikten sonra işçinin iş sözleşmesi devamında oluşabilecek durumlara karşı haklı nedenle fesih hakkı tanınmış olması önemlidir; bu, suçu bildirme yükümlülüğü için bir koruma sağlamasa da mevcut durumda, en azından bir seçenek adeta bir "imdat çıkışı" sağlamış olacaktır.

$\mathrm{Bu}$ sebeple "işverenin işyerinde ya da dişında işçi ve ailesine karş1 olmayan suçların" işçiye haklı nedenle fesih imkânı sağladığının açıkça ifade edilmesi gerektiği düşüncesindeyiz. Ayrıca bu nedeni, suçu bildirme yükümlülügüü sonucunda olabileceklerden bir kaçış yolu olarak önersek de; işçi "işverenin işlediği suçlardan dolayı ona duyduğu güveni yitirmesi" ve "işverenin yanında çalışarak işlediği suça ortak olmak istemeyişi”nden dolayı da haklı nedenle fesih yoluna başvurabilecektir.

Aslında İşK. m. 18/III-c uyarınca suç bildiriminin geçerli sebep olmayacağ 1 açıktır ${ }^{205}$ ve son y1llarda Türk Hukuku'nda da whistleblowing kavramı kapsamında işçinin korunması önem kazanmıştır. Ancak henüz etkin 
bir koruma sağlanamadığından uygulamada işçi zor durumlar yaşamakta ve işvereni ihbarı karşısında çeşitli şekillerde işini kaybetmektedir ${ }^{206}$. Bu sebeple suçu bildirmeme suçu karşısında ihbarda bulunmak zorunda kalan işçinin, ihbar sebebiyle işverenin ona kötü davranmasını veya işten çıkarmasını beklemek ya da yıpratıcı bir süreçten sonra dayanamayı somut olaya göre süreli veya haklı nedenle feshe başvurması yerine; tüm bu sıkıntıları yaşamadan kendisinin derhal iş sözleşmesini haklı nedenle feshetmesi işçinin yararına olabilecektir. Sonuç olarak açıkladıklarımız doğrultusunda İşK. m. 24/II'ye "işverenin işyerinde ya da dışında işçi ve ailesine karşı olmayan suçlar" bakımından uygun bir şekilde ekleme yapılmasının adaletli ve işçinin lehine olacağı düşüncesindeyiz ${ }^{207}$.

\section{1. İşverenin İşçiyi Yanıltması}

İşverenin iş sözleşmesini haklı nedenle feshi düzenlemelerini incelerken bu nedene benzer bir haklı nedeni ele almıştık. Orada, işçi iş sözleşmesinin esaslı noktaları konusunda gerekli vasıflar ve koşullar ile ilgili olarak işvereni yanıltırken; burada da işveren söz konusu esaslı noktaları yanlış göstererek ya da gerçeğe uygun olmayan beyanlarda bulunarak işçiyi yanıltmaktadır. Böyle bir yanıltmayı tespit eden işçi, iş sözleşmesini derhal haklı nedenle feshedebilecektir; çünkü işveren culpa in contrahendo yani sözleşme öncesi sorumluluklarına aykırı davranmış olacaktır ${ }^{208}$. Bu sebeple işverenin iş sözleşmesinde ücret, görev tanımı vs. ilişkin olmak üzere belirttiği hususların, doğru olması gerekecektir.

İşverende olduğu gibi işçinin yanıltılması da Türk Ceza Kanunu anlamında dolandırıcılık suçu teşkil edebilecektir. TCK m. 157'de dolandırıcılık "hileli davranışlarla bir kimseyi aldatıp, onun veya başkasının zararına olarak, kendisine veya başkasına bir yarar sağlanması" şeklinde ifade edilmiştir. Buna göre işçinin yanıltılmasının somut olaya göre dolandırıcılık suçu teşkil

206 Ayrıntılı bilgi için bkz. Aydın, Ufuk: "İş Hukuku Açısından İşçinin Bilgi Uçurması (Whistleblowing)", Anadolu Üniversitesi İktisadi ve İdari Bilimler Fakültesi Sosyal Bilimler Dergisi, Y11: 2002-2003, ss. 79-100; Alp, Mustafa: “Avrupa İnsan Haklar1 Mahkemesi'nin Heinisch/Almanya Kararı Işı̆̆ında Whistleblowing (İşçinin İfşa ve İhbarı) ve İş İlişkisinde İfade Özgürlüğü’, Polat SOYER'e Armağan, DEÜHFD, Yı1: 2013, C.15, Özel Sayı, 2014, ss. 385-422; Alp, Mustafa: Çalışanın İşvereni ve İş Arkadaşlarını İhbar Etmesi (Whistleblowing), Beta Yayıncılık, İstanbul, Aralık 2013, (Whistleblowing); Öktem Songu, İfade Özgürlüğ̈̈, s. 642-644.

Kanunda sayılı haklı nedenlerde ekleme/değişiklik yapılabileceğine yönelik diğer açıklamalar için bkz. III. B. 2 İşverenin Şeref ve Namusa Dokunacak Söz ve Davranışları ve Cinsel Tacizde Bulunması, III. B. 4. İşçinin Diğer İşçi veya Üçüncü Kişilerce Cinsel Tacize Uğramas1

Süzek, s. 683, Mollamahmutoğlu/Astarlı/Baysal, s. 229. 
edebileceği kanaatindeyiz. Örneğin, işveren, cep telefonu mağazasında tezgâhtar olarak çalışmak için iş sözleşmesi yapan işçiyi, telefonların aslında sahte olduğunu bildirmeyerek, habersizce suçuna ortak ediyorsa dolandır1c1lık suçunun gündeme geleceğini düşünmekteyiz. Bir başka örnek, işçi atölyede bir sıvının ambalajlara doldurulup paketlenmesi hizmeti için iş sözleşmesi imzalamıştır. İşçi, iş sözleşmesinde, işyerinin ilaç sektöründe çalıştığı ve paketleme yapacağı maddenin insan sağlığına bir zararı bulunmadığından özel tedbirlere gerek olmadığı konusunda bilgilendirilmiştir. İşci, sadece ürünleri doldurma ve paketleme gibi basit tehlikesiz bir işlem gerçekleştirmesi sebebiyle asgari ücretle derhal işe başlamıştır. Ancak gerçek başkadır. İşveren, insan sağlığına zararlı, izinsiz olarak üretimi ve satışı yasa dışı olan, ilaç sektörü için değil yasa dışı işlerde kullanılması amacıyla ürettiği çok tehlikeli bir maddenin paketlemesi için işçiyi işe almış; ama bu durumu saklamıştır. Kurgulamış olduğumuz bu örnekte, işveren işçiyi yanıltmış, işçinin hem sağlı̆̆ hem de maddi durumu açısından zararına olarak kendi ve başkaları adına yarar sağlamıştır. Bu sebeple de dolandırıcılık suçunun gündeme geleceği söylenebilir. Elbette verdiğimiz örneklerde işverenin davranışları başka suçları da barındırmaktadır. Ama biz işçiyi yanıtlaması bakımından durumu ele almış bulunuyoruz.

Burada, her bir haklı nedende belirttiğimiz üzere gerçekten bir dolandırıcılık suçu meydana gelip gelmediği, ceza mahkûmiyeti kararı çıkıp çıkmayacağı, işçinin haklı nedenle sözleşmeyi feshetmesi açısından önemli değildir $^{209}$. Ancak burada suç teşkil edebilecek bir haklı neden olması yukarıda incelediğimiz bildirim yükümlülüğünü doğurabilmektedir ${ }^{210}$. Verdiğimiz örneklerde dolandırılan işçinin suçun mağduru olmasından dolayı, dolandırıcılık için suçu bildirme yükümlülüğü olmasa da ${ }^{211}$ işyerindeki diğer işçiler için kural olarak bir bildirim yükümlülüğü doğacaktır ${ }^{212}$.

Burada işveren vekilinin hilesinin de bu hüküm kapsamında haklı neden oluşturacağı belirtilmelidir. Çünkü iş sözleşmesinin kuruluşunda işveren vekili hilesi, sözleşme işveren adına yapıldığından, işverenin yanıltması olarak kabul edilecektir ${ }^{213}$.

\footnotetext{
209 Bkz. I. Haklı Nedenle Fesihlerde Ceza Mahkemesi Kararı Gerekliliği ve Ceza Yargılamasının İş Mahkemesi Kararlarına Etkisi

210 II. İş Sözleşmesi Bakımından Suçu Bildirme Yükümlülüğü

211 Bkz. II. B. İşverenin Suçu Bildirme Yükümlülüğü dpn. 42.

212 İşverenin yaptığı davranışların TCK'da karşılık geleceği diğer suçlar bakımından, dolandırılan işçi mağdur ya da zarar gören olmayacağından, bu suçlar bakımından bildirme yükümlülüğü doğacaktır.
}

213 Mollamahmutoğlu/Astarlı/Baysal, s. 230. 


\section{2. İşverenin Şeref ve Namusa Dokunacak Söz ve Davranışları ya da Cinsel Tacizde Bulunması}

İşK. m. 24/II-b'ye göre işveren işçinin veya aile üyelerinden birinin şeref ve namusuna dokunacak şekilde sözler söyler, davranışlarda bulunursa veya işçiye cinsel tacizde bulunursa, işçi iş sözleşmesini derhal haklı nedenle feshedebilir. Madde metninde "işçinin aile üyeleri" ifadesine yer verilmiştir. Doktrinde bundan "işçinin eşi, çocukları ve birlikte oturmasalar bile yakın akrabaları"nın anlaşılması gerektiği belirtilmiştir. Dahası bu kavram içine işçinin imam nikâhlı eşi, hatta imam nikâhı bulunmadan birlikte yaşadığ 1 kişi; işçiyle aralarında akrabalık bağı bulunmayan, ancak, aynı çatı altında birlikte yaşayan kişilerin de dâhil edilmesi gerektiği ileri sürülmüşşür ${ }^{214}$.

İşK. m. 24/II-b' den yola çıkarak işyerinde mobbing (psikolojik taciz) $)^{215}$ sebebiyle iş̧̧inin sözleşmeyi haklı nedenle feshedebileceği de doktrinde belirtilmiş ve bu görüş, m. 24 ikinci bentte yer alan "Ahlak ve iyiniyet kurallarına uymayan haller ve benzerleri" ifadesine dayandırılmıştır" ${ }^{216}$. Yargitay'ın içtihatı da bu yöndedir ${ }^{217}$.

İşçiye uygulanan mobbingi $24 / \mathrm{II}-\mathrm{b}$ bendinin altında ele alsak da, doktrinde bunun aşağıda inceleyeceğimiz sataşmaya ilişkin II-c kapsamına da sokulabileceği belirtilerek; işçiye bağırarak ya da sürekli eleştirerek iş yaptırılması, dış görünüşüyle alay edilmesi, küçümsenmesi, işçi hakkında dedikodu yayılması gibi durumların sataşma olarak değerlendirilebileceği kabul edilmiştir ${ }^{218}$. İşçi, diğer işçilerin mobbinginde ise İşK. m. 24/II-d kapsamında haklı nedenle iş sözleşmesini feshedebilecektir ${ }^{219}$. Ama Yargıtay

\footnotetext{
214 Mollamahmutoğlu/Astarlı/Baysal, s. 231.

215 Mobbing (psikolojik taciz) ile ilgili ayrıntılı bilgi (anlam, örnekler, yargı kararları vb.) için bkz. II. A. 3. İşçinin Cinsel Tacizde Bulunması

216 Eyrenci/Taşkent/Ulucan, s. 243, 244; Süzek, s. 684; Savaş, s. 79; Keser, Hakan: "İş Sözleşmesinin Bildirimli Feshinde Geçerli Sebep”, Güncellenmiş 3. Bask1, Seçkin Yayıncılık, Ankara, Mayıs 2016, s. 334, 340; Taşkent, Savaş/Kurt, Dilek: "Uluslararası Düzenlemeler Çerçevesinde Türk İş Mevzuatında Kadın İşçinin Korunması”, Çalışma ve Toplum Dergisi, 2014/1, S.40, ss. 29-50, s. 44; Öktem Songu, Sataşma, s. 128-129. Mobbing'in "ve benzerleri" kapsamından değerlendirip haklı neden sayılamayacağ şeklindeki aksi görüş için bkz. Şen, s. 61.

İşverenin psikolojik tacizi (mobbing) nedeniyle işçi tarafindan yapılan feshi haklı kabul ettiği kararları için bkz. Y. HGK., 25.09.2013, 2012/9-1925 E., 2013/1407 K.; Y. 9. HD., 15.10.2009, 2008/10408 E., 2009/26968 K.; Y. 9. HD., 01.04.2011, 2009/8046 E., 2011/9717 K., (www.kazanci.com, E.T.:26.06.2020).

218 Öktem Songu, Sataşma, s. 128. Ancak psikolojik tacizin, sataşma kabul edilemeyecek kadar hafif, belirsiz, kurnazca yapılan davranışlardan oluşmasından dolayı İşK. m. 24/IIc hatta II-b kapsamına dahi sokulamayacağı aksi görüşü için bkz. Şen, s. 61.
} 128. 
ve Bölge Adliye Mahkemeleri Kararları mobbing için çoğunlukla dayanak olarak genel anlamda İşK. m. 24/II'yi göstermekte bir alt bent kapsamında değerlendirmemektedir ${ }^{220}$.

Yargitay bu alt bent kapsamında sadece işverenin değil işveren vekilinin belirtilen davranışlarının da haklı nedenle feshe olanak sağlayacağını kabul etmiştir ${ }^{221}$.

Esasen, aşağıda irdeleyeceğimiz "işçinin diğer bir işçi ya da üçüncü kişi tarafından cinsel tacize uğraması"nda olduğu gibi ${ }^{222}$, bu alt bent kapsamındaki davranışlar işveren vekilinin yanı sıra "başka bir işçi veya üçüncü kişi”" tarafından, "işyerinde ya da işyerinde çalışmayı etkileyen bir husus ise işyeri dışında", gerçekleştirildiyse ve işçinin bildirimine rağmen işveren buna yönelik yapılması gerekenleri yerine getirmediyse de işçiye haklı nedenle fesih hakkı tanınması gerektiği kanaatindeyiz. Bu hakkın, bentte sınırlı sayım yapılmadığı görüşüne dayanılarak "ve benzerleri" ifadesi kapsamında mevcut olduğu kabul edilebilir. Ama bu durumda doktrinde, yapılacak feshin spesifik olarak bu bent kapsamında değil genel anlamda sadece İşK. m. 24/II uyarınca feshedilmiş olacağı; ayrıca bu durumun kapsama alınabilme gerekçesinin TBK m. 417'deki işçiyi gözetme borcunun bir gereği olduğu belirtilmiştir ${ }^{223}$. Ancak konunun tartışmaya sebep olmaması için incelemekte olduğumuz İşK. m. 24/II-b'ye "bir başka işçinin veya üçüncü kişinin” ifadesinin eklenmesi veya aşağıda inceleyeceğimiz "bir başka işçi veya üçüncü kişinin cinsel tacizi"ne ilişkin düzenlemeye "şeref ve namusuna dokunacak davranışların" ifadesinin de konması yoluna başvurulabilir. Ama İşK. m. 24/II-b’ye "bir başka işçinin veya üçüncü kişinin” ifadesinin eklenmesi yolu seçilecek olursa atlanmaması gerekecek husus, işçi veya üçüncü kişinin söz konusu davranışları gerçekleştirir gerçekleştirmez işçinin haklı nedenle feshe başvuramayacağı, işçi derhal haber vermesine rağmen işveren herhangi bir tedbir uygulamıyorsa, iş sözleşmesini derhal

220 Bkz. Y. HGK, 02.11.2011, 2011/9-590 E., 2011/677 K., Antalya, BAM, 9. HD., 28.11.2019, 2019/1778 E., 2019/2009 K., (www.kazanci.com, E.T.:10.09.2020).

221 Eyrenci/Taşkent/Ulucan, s. 245; Süzek, s. 684; Mollamahmutoğlu/Astarlı/Baysal, s. 230. Bkz. Y. 9. HD., 14.2.1994, 1993/14090 E., 1994/2244 K., (www.kazanci.com, E.T.:26.06.2020).

222 Bkz. III. B. 4. İşçinin Diğer İşçi veya Üçüncü Kişilerce Cinsel Tacize Uğramas1

223 Ergin, s. 72; Öktem Songu, Sataşma, s. 125. Esasen söz konusu yazarlar bu görüşleri spesifik olarak sataşma için ifade etmiştir. Ancak bu hususta da aynı bakış açısı dikkate alınabilecektir. Mollamahmutoğlu, Astarlı ve Baysal, işverenin bir başka işçisinin işçiye veya aile üyelerinden birine karşı şeref ve namusa dokunacak söz ve davranışlarda bulunması veya cinsel tacizi İş K. m.24/II(b) hükmüne göre, işçiye fesih hakkı vermeyeceğini belirtmiştir (Mollamahmutoğlu/Astarlı/Baysal, s. 230). 
feshedebileceğidir ${ }^{224}$. Sonuç olarak sadece olayın gerçekleşmesi durumunda işçi haklı nedene başvuramayacaktır.

Bu konuda doktrinde de "bir başka işçinin" bu davranışlarının haklı neden sayılmasında sorun görülmese de, "üçünçü kişis"nin yani işyeri dışından birinin belirttiğimiz şekilde düzenlemeye dâhil edilmesi daha zor olacaktır. Şöyle ki, üçüncü kişinin davranışının işveren ya da işveren vekili tarafindan önceden bilinmesi mümkün olmadığında haklı nedenle feshe imkânı vermeyeceği ve haklı nedenle feshin ancak, davranışı işveren veya işveren vekilinin önceden öngörebilmelerine rağmen bunun önüne geçmeye çalışmayarak ya da davranış karşılarında gerçekleşmesine rağmen bu durumu sona erdirebilecekken bir müdahalede bulunmayarak gözetim borcuna aykırı davranmalarıyla mümkün olacağı belirtilmiştir ${ }^{225}$. Bu doğrultuda, getirilecek yenilikte "işveren yetkisi dâhilinde gerekli tedbirleri almazsa" ifadesine yer verilirse sorun çıkmayacaktır. Ancak mevcut düzenleme karşısında bir üçüncü kişinin davranışlarının haklı neden teşkil edip etmeyeceğinin özel olarak ele alınması gerekir. Bu durumda dayanılan hüküm doğrudan m. 24/II-b değil; işverenin işçiyi gözetme borcuna aykırılık nedeniyle genel anlamda İşK. m. 24/II "ahlâk ve iyiniyet kurallarına uymayan haller ve benzerleri" olacaktır ${ }^{226}$.

İşveren vekiline açıkça yer verilmemesini, "işçi veya üçüncü kişi”" kavramına yer verilmemesi kadar önemli görmemekteyiz. Zira işveren vekilinin gerçekleştirdiği davranışları bu bent kapsamında kabul etmede dayanak sadece "ve benzerleri" ifadesi yani sınırlı sayım yapılmamış olması değildir. İşK. m. 2/V uyarınca, İş Kanunu'ndaki işveren için öngörülen her çeşit sorumluluk ve zorunluluklar işveren vekilleri hakkında da uygulanacağından, işveren vekilinin davranışları karşısında bu bent kapsamında işçi sözleşmeyi derhal feshedebilecektir ${ }^{227}$.

İşverenin haklı nedenle sözleşmeyi feshetmesi kapsamındaki gibi burada da cinsel tacizin işyeri veya mesai saatleri içinde mi yoksa dişında mı gerçekleştiğinin bir önemi yoktur $^{228}$.

224 Ergin, s. 72; Öktem Songu, Sataşma, s. 125. Esasen söz konusu yazarlar bu görüşleri sataşma için ifade etmiş̧ir. Ancak bu hususta da aynı bakış açısı dikkate alınabilecektir. Esasen bu görüş sataşma için ifade edilmiştir. Ancak bu hususta da aynı bakış açısı dikkate alınabilecektir. Görüş için bkz. Bakırcı, Kadriye: "İş̧ilerin Üçüncü Kişilerin Saldırısına Uğramaları Halinde İşverenin Sorumluluğu Karar İncelemesi”, Karar İncelemesi, Çimento İşveren Dergisi, C.14, S.3, 2000, ss. 29-31, (İnceleme).

Ergin, s. 72; Öktem Songu, Sataşma, s. 125. Esasen söz konusu yazarlar bu görüşleri sataşma için ifade etmiştir. Ancak bu hususta da aynı bakış açısı dikkate alınabilecektir.

227 Süzek, s. 684.

228 Eyrenci/Taşkent/Ulucan, s. 243. Bkz. Y. 9. HD., 04.11.2010, 2008/37500 E., 2010/31544 K., (www.kazanci.com, E.T.:26.06.2020). 
İşverenin İşK. m. 24/II-b kapsamındaki şeref ve namusa yönelik söz ve davranışlarının aynı zamanda suç teşkil etmesi mümkündür. Ceza Kanunu ile İş Kanunu metinleri karşılaştırıldığında bu alt bentteki haklı nedenin TCK m. 125 kapsamında hakaret suçunu oluşturabileceği görülecektir ${ }^{229}$.

Ayrıca işverenin veya yukarıda belirttiğimiz üzere işveren vekilinin cinsel tacizi ya da mobbingi de TCK anlamında çeşitli suçlara karşılık gelebilecektir. Burada da tekrara düşmemek için işverenin haklı nedenlerindeki cinsel tacize ilişkin açıklamalara atıf yapmakla yetiniyoruz ${ }^{230}$.

İşK. m. 25/II-b kapsamında da TCK anlamında çeşitli suçların oluşabilmesi mümkün olsa da, tüm haklı nedenlerde olduğu gibi feshin geçerliliği için bu bir zorunluluk değildir ${ }^{231}$.

\section{3. İşverenin Sataşması, Hukuka Aykırı Davranışlara Yönlendirmesi ve İşçiye ya da Ailesine Karşı Suç İşlemesi}

İşK. m. 24/II-c alt bendinde işveren işçiye veya aile üyelerinden birine karşı sataşmada bulunur veya gözdağı verirse ya da işçiyi veya aile üyelerinden birini kanuna karşı davranışa özendirir, kışkırtır, sürükler yahut işçiye ve aile üyelerinden birine karşı hapsi gerektiren bir suç işlerse yahut işçi hakkında şeref ve haysiyet kırıcı asılsız ă̆ı isnat veya ithamlarda bulunursa işçinin iş sözleşmesini haklı nedenle feshedebileceği düzenlenmiştir.

İlk olarak hızlıca tekrara kaçmadan belirtmemiz gereken husus buradaki eylemlerin de yukarıda da belirtmiş olduğumuz ${ }^{232}$ gerekçelerle sadece işveren değil işveren vekili tarafindan da işlenmesi durumunda haklı nedenle fesih imkânı sağlayabilmesidir ${ }^{233}$. Ayrıca yine diğer başlıkta belirttiğimiz üzere bu alt bent kapsamında da bir başka işçinin ya da üçüncü kişinin işçiye karş1 sataşma, gözdağ 1 vd. hareketlerini gerçekleştirmesine ilişkin bir açıklamada bulunulmamıştır. Ama bir başka işçinin sataşmasının işverene derhal

229 İşçinin veya aile üyelerinden birinin şeref ve namusuna dokunacak şekilde sözler söylenmesi, davranışlarda bulunulması hususunun TCK m. 125 bakımından değerlendirilmesi "İşçinin Şeref ve Namusuna Dokunacak Söz ve Davranışları" sebebiyle işverenin haklı nedenle feshinde yapılmış olan değerlendirmelerle aynı olacağından burada tekrar yer verilmeyecektir. Bkz. III. A. 2. İşçinin Şeref ve Namusuna Dokunacak Söz ve Davranışları.

230 Bkz. III. A. 3. İşçinin Cinsel Tacizde Bulunması

231 Çelik/Caniklioğlu/Canbolat, s. 579. Bkz. I. Haklı Nedenle Fesihlerde Ceza Mahkemesi Kararı Gerekliliği ve Ceza Yargılamasının İş Mahkemesi Kararlarına Etkisi

232 Bkz. III. B. 2. İşverenin Şeref ve Namusa Dokunacak Söz ve Davranışları ve Cinsel Tacizde Bulunmas1

233 Mollamahmutoğlu/Astarlı/Baysal, s. 232. 
bildirilmesi durumunda genel olarak İşK m. 24/II'ye dayandırılabileceği ${ }^{234}$; ancak işyeri dışından bir kişinin işçiye sataşmasının işçiye haklı nedenle fesih hakk1 verip vermeyeceğinin üzerinde ayrıca durulması gerektiği doktrinde belirtilmiştir ${ }^{235}$. Bu konuda, doğrudan sorumluluk doğar denemeyeceğini ama işveren ya da işveren vekilinin, işyeri dışından bir üçüncü kişinin davranışına müdahale ederek olayı bertaraf edebilmesi mümkünse, yani işveren imkânı olmasına rağmen eylemde bulunmamışsa ya da yetersiz ise bunun işverenin işçiyi gözetme borcuna aykırılık olacağ1 ve bir haklı neden teşkil edebileceği söylenmiştir ${ }^{236}$. Ama II-b alt bendini incelerken ele aldığımız üzere, mevcut düzenleme sebebiyle böyle bir durumda işçi, iş sözleşmesini m. 24/II-c alt bendi kapsamında sataşma nedeniyle değil, işverenin işçiyi gözetme borcuna aykırılık olacağından genel olarak ahlâk ve iyiniyet kurallarına uymayan haller ve benzerleri nedeniyle m. 24/II'ye dayalı olarak haklı nedenle feshedebilecektir ${ }^{237}$.

İşverenin işçiye sataşması bakımından TCK değerlendirilmesi işverenin haklı nedenle feshindeki işçinin sataşması ile paralel olduğundan burada tekrar yer vermeyeceğiz ${ }^{238}$. Ancak İşK. m. 24/II-c'de ek olarak işverenin hukuka aykırılığa yönlendirmesine de yer verilmiştir. Bu bağlamda işçinin hangi hukuka aykırı davranışı doğduysa ve bu doğrultuda hangi suç gündeme gelebilecekse işverenin o suçun azmettiricisi olarak değerlendirilmesi ve o suç ile cezalandırılması mümkün olabilecektir ${ }^{239}$.

Düzenleme açısından işverenin hangi hapsi gerektiren suçu işlediği önemli değildir ve özel olarak mahkûm olma şartı da aranmamıştır ${ }^{240}$. İşverenin eyleminin tespiti ve o eyleme kanunda hapis cezası düzenlenmiş olması, haklı nedenin varlığı için yeterlidir. Bu sebeple de yaptırımı sadece para cezası olan suçlar bu kapsama girmeyecektir ${ }^{241}$. Bununla birlikte her ne kadar iş hukuku kaynaklarında rastlamasak da, hapis ya da adli para cezasının seçimlik yaptırım olarak düzenlenmiş suçlar bakımından ne olacağına da değinmek gerekir. Kanunun lafzına bakarsak "hapis cezası gerektiren" ifadesi sebebiyle adli para cezası da öngörülebilecek suçların kapsam dışı

234 Ergin, s. 72; Öktem Songu, Sataşma, s. 125. Bağlantılı olarak bkz. III. B. 2. İşverenin Şeref ve Namusa Dokunacak Söz ve Davranışları ve Cinsel Tacizde Bulunması

235 Öktem Songu, Sataşma, s. 125.

236 Bakırcı, İnceleme, s. 31.

237 Öktem Songu, Sataşma, s. 125.

238 Bkz. III. A. 4. a. İşçinin Sataşması.

239 Mollamahmutoğlu/Astarlı/Baysal, s. 231.TCK m. 38/I: "Başkasını suç işlemeye azmettiren kişi, işlenen suçun cezası ile cezalandırılır". 
olabileceği söylenebilir. Bu doğrultuda, eğer hâkimin hapis cezası yerine para cezasına da hükmedebilme hakkı o suç için düzenlenmişse, haklı neden ortaya çıkmayacaktır ${ }^{242}$. Sonuç olarak da, seçimlik yaptırım öngörülmüş suçları tartışmasız olarak kapsama dâhil etmek ve belirttiğimiz gibi bir değerlendirme yapılması riskini kaldırmak istenirse "hapis cezasına hükmedilebilecek suçlar" ifadesinin maddeye eklenmesi yerinde olacaktır.

Ayrıca tekrar belirtmeliyiz ki, işverenin işçiye veya ailesine karşı hapsi gerektiren bir suç işlemesi haklı neden olarak düzenlenmişse de, daha önce de ileri sürdüğümüz üzere işverenin işçiye ya da ailesine karşı olmayan suçlarının da belirli bir kapsamda haklı neden olarak kabul edilmesi yerinde olacaktır $^{243}$.

\section{4. İşçinin Diğer İşçi veya Üçüncü Kişilerce Cinsel Tacize Uğraması}

İşverenin kendisinin işçiye cinsel tacizde bulunması İşK. m. 24/II-b'de düzenlenmiştir. Burada II-d alt bendinde ise iş̧̧inin, işverenin başka bir işçisi veya üçüncü kişi (bu kişi işverenin ailesi veya bir yakını da olabilir) tarafından işyerinde cinsel tacize uğraması durumuna yer verilmiştir. Ama bu bende göre haklı nedenin kabulü için, olayın gerçekleşmesi yetmez. İşçinin bu durumu işverene bildirmesine rağmen gerekli önlemleri almamış olması gerekir. Bu hükümdeki "gerekli önlem"in ne ifade ettiği tespit edilmelidir. Kanunu'n gerekçesine göre, "gerekli önlemler", işverenin, olayın tekrar etmemesi için çaba göstermesi, sözgelimi, işçinin çalıştı̆̆l yeri değiştirmesi ya da tacizin ă̆ırliğı karşısında tacizci işçinin işine son vermesi’ne karşılık gelmektedir.

Yukarıda, II-b alt bendini incelerken "işverenin bir başka işçisinin" ya da "üçüncü kişinin" şeref ve namusa dokunacak sözler söylemesi ve davranışlarda bulunması karşısında işverenin gerekli önlemleri almaması durumunda haklı nedenle fesih hakkı doğabileceğini; ama tartışmalı bir durum olmaması için bunun madde metninde açıkça düzenlenebileceğini belirtmiştik. Burada buna ek olarak, işverenin bir başka işçisinin ya da üçüncü kişinin, işçiye karşı sadece cinsel taciz değil başka suçları işlemesi durumunda da gerekli ve kendisinden beklenebilecek tedbirleri almazsa haklı nedenle feshe başvurulabileceği düzenlemesine de yer verilebileceğini düşünmekteyiz.

242 Elbette haklı neden oluşmasa da, süreli fesih yoluna başvurulabilmesi mümkün olacaktır.

243 Bkz. II. C. İşçinin Suçu Bildirme Yükümlülüğü ve III. B. İşçinin Haklı Nedenle İş Sözleşmesini Feshedebilmesi Bakımından 
Ayrıca eğer İşK. m. 24/II-d bendinde "işyerinde gerçekleşen" cinsel taciz olarak açıkça belirtilmiş olduğundan, bu bent kapsamında işverenin bir işçisinin başka bir işçisine işyeri dışında cinsel tacizde bulunması durumunun haklı neden teşkil etmeyeceği ileri sürülse bile; daha önce incelediğimiz üzere İşK. m. 24/II-b veya c kapsamına "bir başka işçi”nin davranışlarının da dahil edilebileceği belirtildiğinden, işverenin bir işçisinin bir başka iş̧̧isine işyeri dışında cinsel tacizi, haklı neden olarak kabul edilebilecektir.

Her ne kadar hükümde cinsel taciz kavramı kullanılmışsa da Yargitay'ın da kabul ettiği üzere işçinin bir başka işçiye mobbingi için de bu haklı neden geçerli olacaktır ${ }^{244}$.

İşK. m. 24/II-d kapsamında oluşabilecek suçlar bakımından ise tekrara düşmemek adına burada yeniden inceleme yapmak yerine, işverenin dayanabileceği haklı nedenler kapsamındaki değerlendirmelerimize gönderme yapmakla yetiniyoruz $^{245}$.

\section{SONUÇ}

İş sözleşmesinin sona ermesi, özellikle iş sözleşmesinin feshi hem Yargıtay kararlarında hem de doktrindeki çalışmalarda en çok rastlanan konudur. Bu hem konunun pek çok olasılığı barındırmasından hem de öneminden kaynaklanır. Özellikle, taraflar bakımından sonuçları düşünüldügünde, bildirim süresine uyulması gerekmemesi ve kıdem tazminatı, işsizlik ödeneği gibi kayıplardan dolayı İşK. m. 24/II, İşK. m. 25/II'de yer alan "Ahlak ve iyi niyet kurallarına uymayan haller ve benzerleri" başlıklı haklı nedenlerin tespiti ayrı bir önem arz eder. Çalışmamızda da bu haklı nedenler incelenmiş; ancak konu daha önceki çalışmalardan farklı bir bakış açısıyla da değerlendirilmiştir. Doktrinde haklı nedenler incelenirken, buradaki eylemlerin suç teşkil edebileceği belirtilir. Ancak bunun haklı nedenle fesih için bir gereklilik olmamasından dolayı, bir suç açıkça haklı neden olarak sayılmadıkça söz konusu nedenin suç teşkil edip etmeyeceği değerlendirmesinde bulunulmamıştır. Ama biz çalışmamızda haklı nedenleri suç niteliği taşıması yönüyle de incelemiş ve bu doğrultuda İşK. m. 24/II ve m. 25/II'i tek tek ele almış bulunuyoruz.

Bir eylemin haklı neden sayılabilmesi için onun suç niteliği taşıması ve suç niteliği taşıyorsa bununla ilgili bir mahkûmiyet kararı verilmesi gerek-

\footnotetext{
244 Mollamahmutoğlu/Astarlı/Baysal, s. 233, Öktem Songu, Sataşma, s. 128. Mobbing (psikolojik taciz) ile ilgili ayrıntılı bilgi (anlam, örnekler, yargı kararları vb.) için bkz. II. A. 3. İşçinin Cinsel Tacizde Bulunması. 
mez. Ancak buna rağmen özellikle TCK'da açıkça suç olarak düzenlenen kavramlar bakımından haklı nedenlerin ceza ve ceza muhakemesi hukuku ile bağlantılı olarak ele alınması gereklidir. Çünkü bu kavramlar iş hukukuna ait değildir ve anlamlandırıp hükümlerin uygulanması açısından ceza hukuku ve mevzuatı doğrultusunda inceleme yapmak gerekir. Bunun yanı sıra, haklı neden bakımından ceza mahkemesi kararı aranmıyor ya da verilen bir beraat kararı ile bağlı olunmuyorsa da, iş mahkemesi hâkimi, elindeki somut olayla ilgili maddi gerçekler söz konusuysa ceza mahkemesi kararlarını dikkate almak zorundadır.

Ayrıca çalışmamızda haklı nedenlerin suç teşkil edip etmediğinin incelenmesi, esas olarak işçinin ve işverenin suçu bildirme yükümlülüğü bakımından önem arz eder. Suçu bildirme yükümlülüğünün haklı nedenle fesih konusunda iki yönü bulunmaktadır. İlk olarak, haklı neden sayılan bir eylemin suç teşkil ettiğinin tespiti, suçu bildirmeme suçunun ihlal edilmemesi bakımından önemlidir. Zaten bu doğrultuda haklı neden olarak sayılan eylemlerin hangi suçlara karşılık gelebileceğini tek tek ele almaya çalıştık. Ama konu başlığımız bakımından bir diğer önemli husus, suçu bildirme yükümlülüğünün, suç niteliği taşıyan bir eylem karşısında işçi ve işverene iş ilişkisinde yaşatabileceği zorluklardır.

Durumu ilk olarak işveren açısından ele aldığımızda, işçisinin faili olduğu bir suç bakımından işverenin iş sözleşmesini feshetmemesi ya da geçerli nedenle feshedebilmesi seçeneği varken, suçu bildirme yükümlülüğü sebebiyle işçiyi ihbar etmek zorunda kaldığından, işverenin haklı nedenle feshe başvurması adeta bir zorunluk haline gelmiştir. Zira ihbar edilen bir işçi ile iş ilişkisini güven içinde, zarar görmeden sürdürülebileceğini düşünmek hayatın olağan akışına uymayacaktır.

Suçu bildirme yükümlülüğü, iş ilişkisindeki konumu gereği işçiyi işverene göre daha zor bir duruma sokacaktır. İşçi, işvereni/işveren vekilini ya da bir diğer işçiyi ihbar ettikten sonra artık karşıllklı güven ilişkisi içinde çalışılması mümkün olmayacağından, dahası ihbar ettiği kişiler karşısında fiziksel ya da ruhsal (mobbing, sataşma gibi) açılardan tehlike altında olabileceğinden iş sözleşmesini derhal feshetmek zorunda kalacaktır. Ama işçi her şeyi göze alıp iş sözleşmesini derhal feshetmese de, ilerleyen süreçte İşK. m. 18/III-c'de "mevzuattan veya sözleşmeden doğan haklarını takip veya yükümlülüklerini yerine getirmek için işveren aleyhine idari veya adli makamlara başvurmak veya bu hususta başlatılmış sürece katılma" nın geçerli sebep olmayacağı belirtilmesine rağmen iş sözleşmesi işverence çeşitli nedenlerle sona erdirilebilecek ya da işçi işyerinde yaşadıklarına dayanamayıp somut olaya göre haklı nedenle derhal ya da süreli fesih yoluyla iş sözleşmesini sona erdirebilecektir. Sonuç olarak işçinin suçu bildirme/ 
ihbar yükümlülüğü karşısındaki bu zor durumu gidermek için kabul edilmiş İşK. m. 18/III-c yeterli olmayacaktır. İşçinin suçu bildirme yükümlülüğü karşısında yaşayacağı zor durumlar sadece belirttiğimiz mobbing, sataşma ya da iş sözleşmesinin sona ermesiyle de sınırlı değildir. İşçi, işvereni/işveren vekilini ya da bir diğer işçiyi ihbar etmesi sebebiyle fişlenip yeni iş bulmakta da zorlanabilecektir. Bu sebeple her ne kadar haklı nedenle fesih işçinin sorunları için tam bir çözüm olmasa da işçiye tehlikelere karşı bir kaçış yolu sunmuş olmaktadır. 


\section{KAYNAKÇA}

Albayrak Gül, Hande: "İşçinin Sadakat Borcu”, Bahçeşehir Üniversitesi Hukuk Fakültesi Dergisi, Y1l: 2016, C.11, Say1: 141-142, ss. 121-197.

Alp, Mustafa: “Avrupa İnsan Hakları Mahkemesi'nin Heinisch/Almanya Kararı Işı̆̆ında Whistleblowing (İşçinin İşa ve İhbarı) ve İş İlişkisinde İfade Özgürlüğü’, Polat SOYER'e Armağan, DEÜHFD, Y11: 2013, C. 15, Özel Say1, 2014, ss. 385-422.

Alp, Mustafa: “İş İlişkisinin Sona Ermesi ve Kıdem Tazminatı", Yargıtay’ın İş Hukuku ve Sosyal Güvenlik Hukuku Kararlarının Değerlendirilmesi 2013, 2. Bask1, Onikilevha Yayınc1l1k, İstanbul, Kasım 2017, ss. 175257, (Değerlendirme).

Alp, Mustafa: Çalışanın İşvereni ve İş Arkadaşlarını İhbar Etmesi (Whistleblowing), Beta Yayıncılik, İstanbul, Aralı 2013, (Whistleblowing).

Alpagut, Gülsevil: "İşçinin Sadakat Borcu ve Türk Borçlar Kanunu ile Getirilen Düzenlemeler”, Sicil İHD, Y11: 7, S. 25, Mart 2012, ss. 23-32.

Arı, Mehmet: "İşçinin Sır Saklama Yükümlülüğü”, Terazi Hukuk Dergisi, C. 11, S. 115, 2016, ss. 58-63.

Arslan Durmuş, Seda: İşverenin Haklı Nedenle Fesih Hakkı, Onikilevha Yayınc1l1k, İstanbul, 2012.

Arslan Ertürk, Arzu: Türk İş Hukuku'nda Sadakat Borcu, Doktora Tezi, İstanbul 2007.

Arslantürk, Mustafa: Türk Ceza Kanunu Uygulamasında Cinsel Suçlar, Güncellenmiş ve Genişletilmiş 3. Baskı, Seçkin Yayıncılık, Ankara, Mart 2017.

Astarlı, Muhittin: "İşs İlişkisinin Sona Ermesi ve Kıdem Tazminatı", Yargıtay'ın İş Hukuku ve Sosyal Güvenlik Hukuku Kararlarının Değerlendirilmesi 2015, Onikilevha Yayınc1lı, İstanbul, Kasım 2017, ss. 211-383.

Atabek, Reşat: İş Akdinin Feshi, Arkadaş Basımevi, İstanbul, 1938,

Aydın, Ufuk: "İş Hukuku Açısından İşçinin Bilgi Uçurması (Whistleblowing)", Anadolu Üniversitesi İktisadi ve İdari Bilimler Fakültesi Sosyal Bilimler Dergisi, Y11: 2002-2003, ss. 79-100.

Aydın, Ufuk: İş Hukuku'nda İşçinin Kişilik Hakları, Anadolu Üniversitesi Yayınları, 2002.

Bakırcı, Kadriye: "İşçilerin Üçüncü Kişilerin Saldırısına Uğramaları Halinde İşverenin Sorumluluğu", Karar İnceleme, Çimento İşveren Dergisi, C. 14, S. 3, 2000, ss. 29-31, (İnceleme). 
Bakırcı, Kadriye: İşyerinde Cinsel Taciz, Yasa Yayıncılık, İstanbul, 2000.

Baycık, Gaye: "İş İlişkisinin Kurulması, Hükümleri ve İşin Düzenlenmesi”, Yargıtay'ın İş Hukuku ve Sosyal Güvenlik Hukuku Kararlarının Değerlendirilmesi 2016, 2. Bask1, Onikilevha Yayıncılık, İstanbul, Kasim 2018, ss. 7-355.

Bayram, Fuat: "Türk İş Hukuku Açısından İşyerinde Psikolojik Taciz (Mobbing)", Legal İSGHD, Y11: 2007, C. 4, S. 14, ss. 551-574.

Baysal, Ulaş: İşçinin Yetersizliğinden Kaynaklanan Geçerli Sebeple İş Sözleşmesinin Feshi, Adalet Yayınevi, Ankara, Kasım 2011.

Bedük, Mehmet Nusret: "İş Sözleşmesinin İşçi Tarafından Feshi ve Feshin Hukuki Sonuçları”, Selçuk Üniversitesi Hukuk Fakültesi Dergisi, Yı1: 2019, C. 27, S. 3, ss. 679-726.

Bilgili, Abbas: İş Hukuku Açısından İş Yerinde Cinsel Taciz, Karahan Kitabevi, Adana, 2010.

Birben, Erhan: “İşçinin Özel Yaşamı Nedeniyle İş Sözleşmesinin Feshi”, İş Hukukunda Genç Yaklaşımlar II, On İki Levha Yayıncılık, İstanbul, Ekim 2016, ss. 135-169.

Büyükkılıç, Gül: "İş Hukuku Çerçevesinde İşyerinde Psikolojik Taciz (Mobbing) Olgusunun Değerlendirilmesi, ”, Legal İSGHD, Y1l: 2012, C. 9, S. 33, ss. 89-160.

Bozbel, Savaş/Palaz, Serap: "İşyerinde Psikolojik Taciz (Mobbing) ve Hukuki Sonuçları" TİSK Akademi, Yıl: 2007/I, C. 2, S. 3, 2007 /I, ss. 66-81.

Caniklioğlu, Nurşen: "İş İlişkisinin Sona Ermesi ve Kıdem Tazminatı", Yargıtay'ın İş Hukuku ve Sosyal Güvenlik Hukuku Kararlarının Değerlendirilmesi 2017, Onikilevha Yayıncılık, İstanbul, Kasım 2019, ss. 185-368.

Centel, Tankut, “Türk Borçlar Kanunu'nda Genel Olarak İşçinin Kişiliğinin Korunmas1", Sicil İHD, Y11: 6, S. 24, Aralık 2011, ss. 13-18.

Çelik, Nuri/Caniklioğlu, Nurşen/Canbolat, Talat, İş̧ Hukuku Dersleri, Yenilenmiş 31. Bası, Beta Yayıncılık, İstanbul, Eylül, 2018.

Demir, Fevzi: İş Hukuku ve Uygulaması, 11. Baskı, Albi Yayınları, İzmir, Eylül 2018.

Dişel, Buse: "Ceza Mahkemesinin Mahkûmiyet Kararının Hukuk Mahkemesi Kararına Etkisi ve Bekletici Sorun Yapılması", Prof. Dr. Bilge Umar'a Armağan I, İzmir, 2010, DEÜHFD, Y11: 2009, C. 11, Özel Say1, ss. 183-224.

Doğan Yenisey, Kübra: "İş İlişkisinin Kurulması, Hükümleri ve İşin Düzenlenmesi”, Yargitay’ın İş Hukuku ve Sosyal Güvenlik Hukuku 
Kararlarının Değerlendirilmesi 2013, 2. Baskı, Onikilevha Yayıncılık, İstanbul, Kasim 2017, ss. 7-145.

Döner, İsa: "Suçu Bildirmeme Suçu (TCK m. 278)", AÜEHFD, Y11:2005, C.: IX, S. 3-4, ss. 63-94.

Engin, Murat: “İş İlişkisinin Sona Ermesi ve Kıdem Tazminatı”, Yargıtay'ın İş Hukuku ve Sosyal Güvenlik Hukuku Kararlarının Değerlendirilmesi 2014, 2. Bask1, Onikilevha Yayıncılık, İstanbul, Kasım 2017, ss. 131193.

Erdem, Mustafa Ruhan: "Suçu Bildirmeme Suçu (TCK m. 278)", TBB Dergisi, S. 80, 2009, ss. 105-120.

Erdem, Mustafa Ruhan/Parlak, Benay: "Ceza Hukuku Boyutuyla Mobbing”, TBB Dergisi, S. 88, 2010, ss. 261-286.

Erdoğan, Canan: Kişilik Hakkı Kapsamında İşçilerin İzlenmesi ve Gözetlenmesi, Yetkin Yayınları, Ankara, 2017.

Erem, Faruk: "Ceza Hukuku'nda Meslek Sirrı”, AÜHFD, C. 1, S. 1, 1943, ss. 35-72, (Meslek Sirri).

Erem, Faruk: "Avukatlık Sirrı”, Ankara Barosu Dergisi, Yı1: 1969, S. 5, ss. 838-841.

Ergin, Hediye: "İşçinin İşyerinde Çalışan Diğer Bir İşçiye Sataşması Nedeniyle İş Sözleşmesinin İşveren Tarafından Feshi”, Sicil İHD, Y1l: 2015, S. 34, ss. 71-87.

Erkanlı Başbüyük, Betül: "İş Görmekten Kaçınma Sebebi Olarak İşyerinde Cinsel Taciz", Legal İSGHD, Y11: 2019, C. 16, S. 61, ss. 127-180, (Cinsel Taciz).

Erkanlı Başbüyük, Betül: Tarafların İşs sözleşmesinin Yapılması Sırasındaki Hak ve Yükümlülükleri, Adalet Yayınevi, Ankara, Mart 2015.

Ertürk, Şükran: İş İlişkisinde Temel Haklar, Seçkin Yayıncılık, Ankara, Mayıs 2002.

Eyrenci, Öner: "İşe Girişte Personel Seçimi İle İlgili Hukuki Sorunlar", İş Hukuku ve Sosyal Güvenlik Hukuku Türk Milli Komitesi 15. Y1l Armağanı, Bayrak Matbaacılık, 1991, ss. 239-262.

Eyrenci, Öner/Taşkent, Savaş/Ulucan, Devrim: Bireysel İş Hukuku, 9. Bask1, Beta Yayınc1lı, İstanbul, Mart 2019.

Gerek, Nüvit: "İşveren Tarafından Gerçekleştirilen Haksız Fesih-Usulsüz Fesih-Kötü Niyetli Fesih”, Kara Tahta İş Yazıları Dergisi, Yı1: 2015, S. 2, ss. 1-17. 
Giyik, Abdülbaki: "Hekimin Sır Saklama Yükümlülüğü ile Suçu Bildirme Yükümlülüğü ve Bu Yükümlülüklerin Çatışması”, Erciyes Üniversitesi Hukuk Fakültesi Dergisi, Cilt: IX, Say1: 2, 2014, ss. 175-214.

Güzel, Ali: “İş İlişskisinin Sona Ermesi ve Kıdem Tazminatı", Yargıtay’ın İş̧ Hukuku ve Sosyal Güvenlik Hukuku Kararlarının Değerlendirilmesi 2010, Kamu-Işs, Ankara, Ekim 2012, ss. 133-284.

Güzel, Ali/Ertan, Emre: "İşyerinde Psikolojik Tacize (Mobbinge) Hukuksal Bakış: Avrupa Hukuku ve Karşılaştırmalı Hukuk", Legal İSGHD, Yı1: 2007, C. 4, S. 14, ss. 509-549.

Güzel, Ali/Ertan, Emre: "İ̧syeri Sendika Temsilcisine Yönelik Psikolojik Taciz ve Kötüniyet Tazminatı (Karar İncelemesi)”, Çalışma ve Toplum Dergisi, 2008/1, S. 16, (İnceleme), ss. 149-170.

Hafızoğulları, Zeki/Acar, Bülent Hayri: "Suçu Bildirmeme Suçları", Başkent Üniversitesi Hukuk Fakültesi Dergisi, Ocak 2016, C. 2, S. 1, ss. 179-198.

Hüseyinli, Namık/Aslan Atabay, Hatice: "Psikolojik Tacizin İçtihatlar Işığında Uygulamadaki Yeri”, İnönü Üniversitesi Hukuk Fakültesi Dergisi, Y11: 2017, C. 8, S. 2, ss. 603-636.

Işık, Göksu: "Hukuki Güvenlik İlkesi Bağlamında Suçu Bildirmeme Suçu", Beykent Üniversitesi Hukuk Fakültesi Dergisi, C. 3, S. 7, Aralık 2017, ss. 163-187.

Kapancı, Kadir Berk: "Ceza Mahkemesi Kararlarının Hukuk Mahkemesi Kararlarına Etkisi (TBK m. 74)", İnönü Üniversitesi Hukuk Fakültesi Dergisi, Y1l: 2016, C. 7, S. 1, ss. 511-552.

Keser, Hakan: "İş Sözleşmesinin Bildirimli Feshinde Geçerli Sebep", Güncellenmiş 3. Baskı, Seçkin Yayıncılık, Ankara, Mayıs 2016.

Kitapçıoğlu Yüksel, Tülay: "Meslek ve Sürekli Uğraşıları Sebebiyle Tanıklıktan Çekinme Yükümlülüğü Altındaki Kişilerin Suçu Bildirme Yükümlülüğü’, Ceza Hukuku Dergisi, CHD, Yıl: 13, S. 38, Aralık 2018, ss. 193-215.

Koca, Mahmut/Üzülmez, İlhan: Türk Ceza Hukuku Özel Hükümler, 6. Bask1, Adalet Yayınevi, Ankara, Ekim, 2019.

Kocaoğlu, Serhat Sinan: Hakaret Suçu, Seçkin Yayıncılık, Ankara, Mart 2019.

Kocasakal, Ümit: Suçu Bildirmeme Suçları, Vedat Kitapçılık, İstanbul, Temmuz 2017.

Kolcu, Selahattin: Suçu Bildirmeme Suçu, Seçkin Yayıncılık, Ankara, Kasım 2016. 
Köseoğlu, Ali Cengiz: İş Sözleşmesinin İşçiden Kaynaklanan Nedenlerle Bildirimli Feshi, Beta Yayıncılık, İstanbul, 2011.

Limoncuoğlu, Alp: "İşçinin İş Sözleşmesini Psikolojik Tacize Dayalı Olarak Haklı Nedenle Feshinde Hak Düşürücü Sürenin Başlangıc1 (Karar İncelemesi)", Polat SOYER'e Armağan, DEÜHFD, Y11: 2013, C. 15, Özel Sayı, 2014, ss. 547-571.

Mollamahmutoğlu, Hamdi/Astarlı, Muhittin/Baysal, Ulaş: İş Hukuku Ders Kitabı, Cilt 1: Bireysel İş Hukuku, Gözden Geçirilmiş 3. Bask1, Lykeion Yayınları, Ankara, Eylül 2019.

Narmanlıŏglu, Ünal: İş Hukuku Ferdi İş İlişkileri I, Beta Yayıncılık, 5. Bas1, İstanbul, Aralık 2014.

Odaman, Serkan: "İşçinin İşe Başvuru Esnasında İşvereni Yanıltması ve Hukuki Sonuçları", Tekstil İşveren Dergisi, Ekim-2002, S. 274, ss. 4043, (İşçinin İşvereni Yanıltması).

Odaman, Serkan: İşverenin Hizmet Sözleşmesini Ahlak ve İyiniyet Kuralları ve Benzerlerine Aykırılık Nedeniyle Fesih Hakkı", Ankara, 2003, (Ahlak ve İyiniyet Kuralları ve Benzerleri).

Odaman, Serkan: "İş İliş̧isinin Sona Ermesi ve Kıdem Tazminatı", Yargıtay'ın İş Hukuku ve Sosyal Güvenlik Hukuku Kararlarının Değerlendirilmesi 2011, Kamu-İş, Ankara, Kasım 2013, ss. 131-234.

Okur, Zeki: İş Hukuku'nda Elektronik Gözetleme, Legal Kitapevi, İstanbul, Ekim 2011.

Öktem Songu, Sezgi: "Bir Haklı Fesih Sebebi Olarak 'Sataşma”, Sicil İHD, Y11: 2018, S. 39, ss. 113-145, (Sataşma).

Öktem Songu, Sezgi: “Anayasal Bir Temel Hak Olarak İfade Özgürlüğünün İşçi Açısından İşyerindeki Yansımaları”, Polat SOYER'e Armağan, DEÜHFD, Y11: 2013, C. 15, Özel Say1, 2014, ss. 609-650, (İfade Özgürlüğü).

Öktem Songu, Sezgi: "İşçilerin İşyerinde Özel Amaçlı İnternet ve E-Posta Kullanımına İşverenin Müdahalesi Üzerine Bir Değerlendirme”, Sarper SÜZEK'e Armağan, C. I, Beta Yayıncılık, İstanbul 2011, ss. 10571098.

Özbek, Veli Özer/Doğan, Koray/Bacaksız, Pınar: Ceza Muhakemesi Hukuku, Gözden Geçirilmiş ve Güncellenmiş 12. Bask1, Seçkin Yayıncılık, Ankara, Ağustos 2019, (Ceza Muhakemesi).

Özbek, Veli Özer/Doğan, Koray/Bacaksız, Pınar: Türk Ceza Özel Hukuku Özel Hükümler, Genişletilmiş ve Güncellenmiş 14. Baskı, Seçkin Yayıncılık, Ankara, Eylül 2019. 
Özbek, Veli Özer/Meraklı, Serkan: "Ceza Hukukunda Avukatın Kamu Görevlisi Olarak Kabul Edilebilirliği Sorunu", Dr. Dr. h. c Silvia TELLENBACH'a ARMAĞAN, Seçkin Yayıncılık, Ankara, Mayıs 2018, ss. 1157-1176.

Özen, Mustafa: Öğreti ve Uygulama Işığında Ceza Hukuku Özel Hükümler, Adalet Yayinevi, Ankara, Ekim 2017.

Öztürk, Bahri/Tezcan, Durmuş/Erdem, Mustafa Ruhan ve Diğerleri: Nazari ve Uygulamalı Ceza Muhakemesi Hukuku, Güncellenmiş 13. Baskı, Seçkin Yayıncılık, Ankara, Eylül 2019.

Savaş, F. Burcu: İş Sözleşmesinin İşveren Tarafindan Haklı Nedenle Feshi, Beta Yayınc1lık, 2012.

Savaş Kutsal, F. Burcu: "İşyerinde Psikolojik Taciz (Mobbing)", Toprak İşveren Dergisi, Y11: 2015, S. 105, Mart 2015, (Makale Format1), ss. 114, (www.toprakisveren.org.tr/140-isyerinde-Psikolojik-TacizMOBBiNG.Makale, E.T.: 11.09.2020).

Senyen Kaplan, Emine Tuncay: "İş Hukukunda Kişilik Haklarının Özellikle Bilgisayarda Toplanan Bilgilere Karşı Korunması", Prof. Dr. Cemal MIHÇIOĞLU'na Armağan, Ankara Üniversitesi SBF Dergisi, 1997, C. 52, ss. 367-386, (Bilgisayar Bakımından İşçinin Kişilik Hakları).

Senyen Kaplan, Emine Tuncay: Bireysel İş Hukuku, Yenilenmiş 8. Bask1, Gazi Kitabevi, Ankara, Eylül 2017, (İş Hukuku).

Senyen Kaplan, Emine Tuncay: Mukayeseli İş Hukukunda İşçinin Kişilik Haklarının Bilgisayarda Toplanan Verilere Karşı Korunması, Kamu İş Dergisi, Y1l: 1999, S. 4, ss. 367-386.

Sungurtekin Özkan, Meral: “Avukatllk Meslek Sırrının Anlam ve Önemi”, Hukuk Kurultayı 2000, Ankara Barosu, Ankara 2000, ss. 331-338.

Süzek, Sarper: İş Hukuku, Yenilenmiş 18. Baskı, Beta Yayıncılık, İstanbul, Eylül 2019.

Şen, Sabahattin: "Psikolojik Taciz ve İş Kanunu Boyutu", Çimento İşveren Dergisi, Y11: 2009, C. 23, S. 5, ss. 46-68.

Taşkent, Savaş/Kurt, Dilek: "Uluslararası Düzenlemeler Çerçevesinde Türk İş Mevzuatında Kadın İşçinin Korunması”, Çalışma ve Toplum Dergisi, 2014/1, S. 40, ss. 29-50.

Taşkın, Ahmet: "İşyerinde Mobbingin Ceza Hukuku Bakımından Değerlendirilmesi”, Çalışma ve Toplum Dergisi, 2015/1, ss. 221-258.

Tezcan, Durmuş/Erdem, Mustafa Ruhan/Önok, R. Murat: Teorik ve Pratik Ceza Özel Hukuku, Güncellenmiş 17. Baskı, Seçkin Yayıncılık, Ankara 2019. 
Törenli Çakıroğlu, Maral: "Hekimin Borçlarından Özel Olarak Sır Saklama Borcu”, DEÜHFD, Y11: 2010, C. 12 S. 2, ss. 159-181.

Tunçomağ, Kenan/Centel, Tankut: İş Hukukunun Esasları, Yenilenmiş ve Gözden Geçirilmiş 8. Bask1, Beta Yayıncılık, İstanbul, Eylül 2016.

Ünal, Canan: "Karşılaştırmalı Hukuk Işı̆̆ında İşyerinde Psikolojik Tacizin İşverenin İşçinin Kişiliğini Koruma ve Eşit Davranma Borcu Kapsamında Değerlendirilmesi”, Legal İSGHD, Y11: 2013, C. 10, S. 37, ss. 33-73.

Ünlü, Vahap: "İş Başvurusu Sırasında İşçinin İşvereni Yanıltması", Sicil İHD, Y11: 4, S. 14, Haziran 2009, ss. 276-283.

Ünver, Yener: İftira, Suç Uydurma, Suç Üstlenme, Yalan Tanıklık ve Bilirkişilik, İnfaz Kurumlarından Kaçma, 4. Baskı, Seçkin Yayıncılık, Ankara, Haziran 2016.

Yağlıdere, Umut Emre: "Sağlık Mesleği Mensuplarının Suçu Bildirmemesi Suçu (Türk Ceza Kanunu m. 280), Kadir Has Üniversitesi Hukuk Fakültesi Dergisi, C. 6, S. 1, Haziran 2018, ss. 59-79.

Hüseyinli, Namı/Aslan Atabay, Hatice: "Psikolojik Tacizin İçtihatlar Işı̆ğında Uygulamadaki Yeri”, İnönü Üniversitesi Hukuk Fakültesi Dergisi, Y1l: 2017, C. 8, S. 2, ss. 603-636.

Yamakoğlu, Efe: Bilişim Teknolojilerinin Kullanımının İş Sözleşmesi Taraflarının Fesih Hakkına Etkisi, Onikilevha Yayıncılık, İstanbul, Ocak 2020.

Yurtcan, Erdener: Yargıtay Kararları Işığında Hakaret Suçları, 4. Bası, Seçkin Yayınc1lık, 2019.

Yürekli, Sabahattin: Türk Borçlar Kanununa Göre Hizmet Sözleşmesinin Sona Ermesi, Güncellenmiş 3. Baskı, Seçkin Yayıncılık, Ankara, Temmuz 2016.

Yokuş Sevük, Hande: Türk Ceza Hukuku Özel Hükümler, Adalet Yayınevi, Ankara, Kasım 2018. 